\title{
Regional Hydrothermal Commercialization Plan
}

4

1

U

1

L

1

1

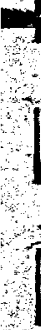

1

1

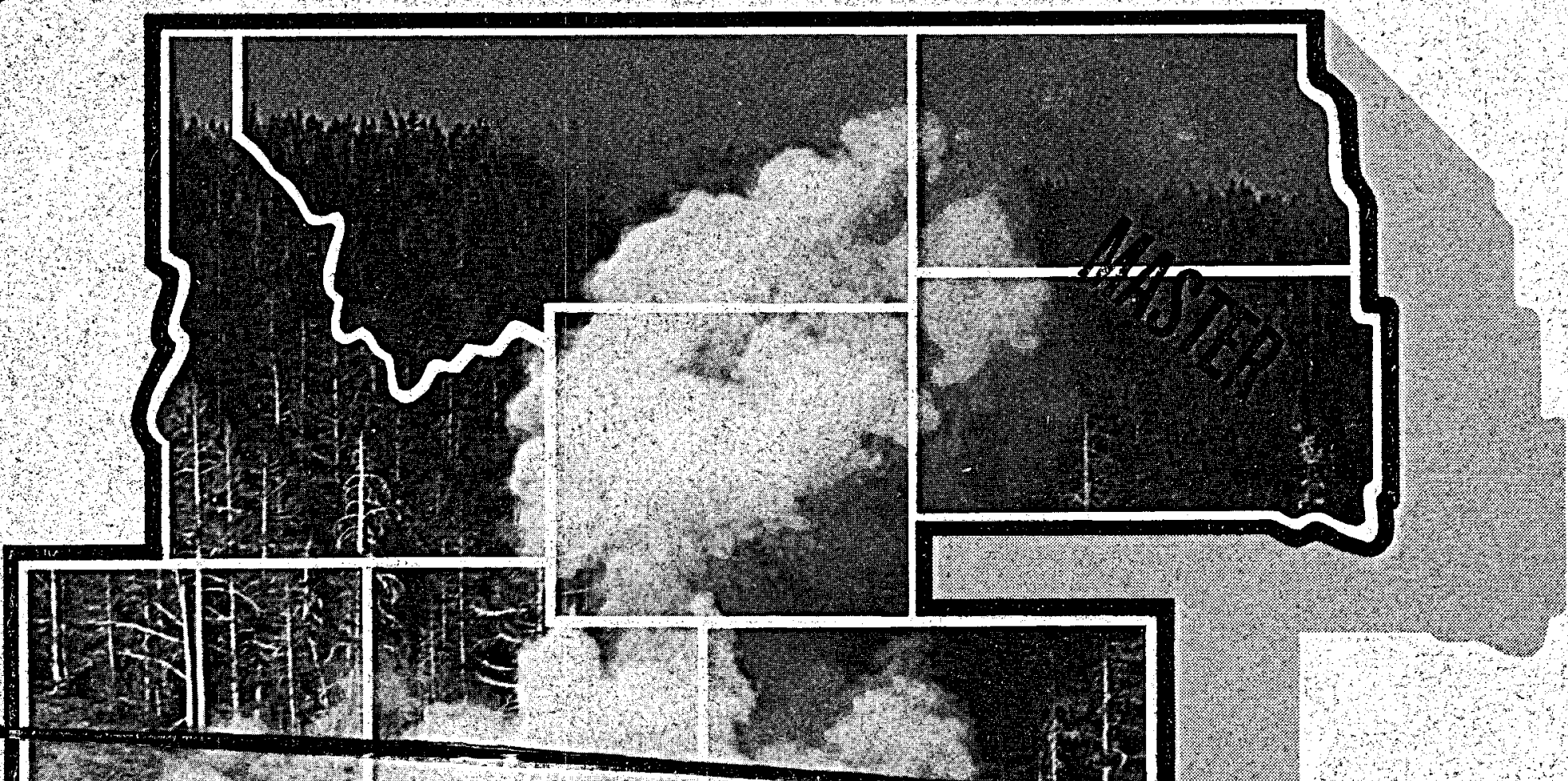

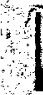
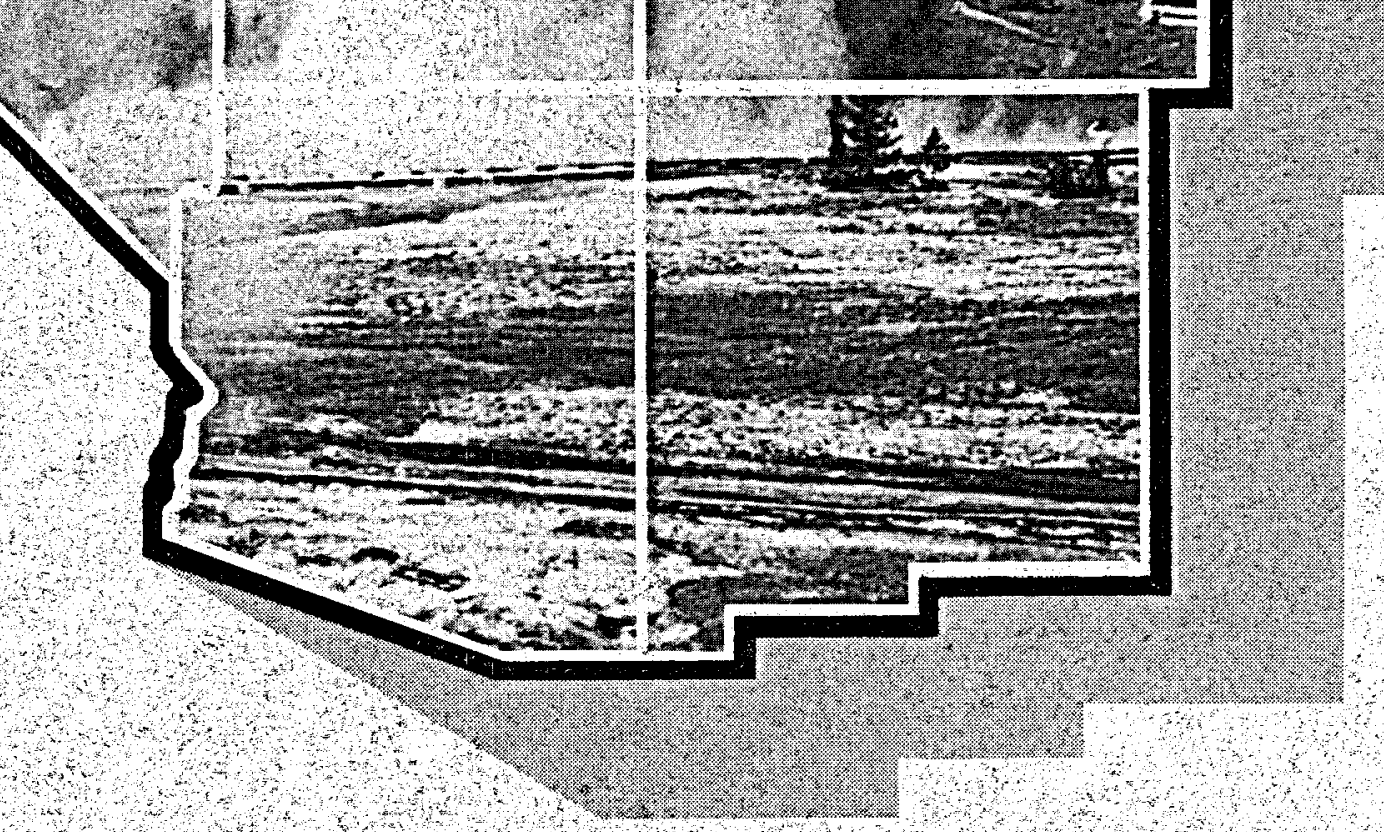

1

1

$$
10
$$

Rocky Mountain Basin and Range Region 


\section{DISCLAIMER}

This report was prepared as an account of work sponsored by an agency of the United States Government. Neither the United States Government nor any agency Thereof, nor any of their employees, makes any warranty, express or implied, or assumes any legal liability or responsibility for the accuracy, completeness, or usefulness of any information, apparatus, product, or process disclosed, or represents that its use would not infringe privately owned rights. Reference herein to any specific commercial product, process, or service by trade name, trademark, manufacturer, or otherwise does not necessarily constitute or imply its endorsement, recommendation, or favoring by the United States Government or any agency thereof. The views and opinions of authors expressed herein do not necessarily state or reflect those of the United States Government or any agency thereof. 


\section{DISCLAIMER}

Portions of this document may be illegible in electronic image products. Images are produced from the best available original document. 
This book was prepared as an account of work sponsored by an agency of the Unitred States Government. Neither the United States Government nor any saency thereof, nor any of their employses, makes any

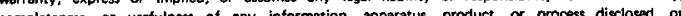

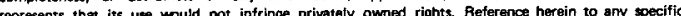
Com not necoserily conesitute or imply Its endarsement, recommendation, or favoring by the Unitod States Government or any asency thereof. The views and copinions of authors expressed herein do not necessarily state or reflect those of the United States Government or any agency therbof.

\section{REGIONAL HYDROTHERMAL COMMERCIALIZATION PLAN}

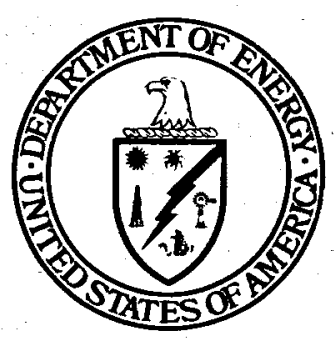

PREPARED BY

DPEARTMENT OF ENERGY - DIVISION OF GEOTHERMAL ENERGY,$a_{0}^{4} 5^{93^{8}}$
DEPARTMENT OF ENERGY - IDAHO OPERATIONS OFFICE $-a S^{0}$ UNIVERSITY OF UTAH RESEARCH INSTITUTE EARTH SCIENCE LABORATORY 9504232

JULY 14, 1978 


\section{PREFACE}

The nature of geothermal resources changes from region to region, as do the economic and demographic factors that affect commercialization of these resources. Consequently, the Department of Energy's Division of Geothermal Energy has regionalized the Department of Energy activities that will lead directly to the commercial exploitation of geothermal fluids for electric and direct heat applications.

The Rocky Mountain Basin and Range (RMB\&R) Region, one of three national hydrothermal regions, consists of the states of Arizona, Colorado, Idaho, Montana, Nevada, New Mexico, North Dakota, South Dakota, Utah and Wyoming. The Idaho Operations Office will manage the implementation of the Rocky Mountain Basin and Range regional program, with principal assistance from EG\&G Idaho, Inc. (prime contractor at the Idaho National Engineering Laboratory) and the University of Utah/University of Utah Research Institute (UU/UURI). Department of Energy geothermal activities in the region were formerly organized and directed on a generic basis, but reorganization has given the program a mission orientation (i.e., power-on-line orientation) in a regional setting. This commercialization plan for the Rocky Mountain Basin and Range Region articulates the complete range of initiatives (federal, state, local, and industrial) required for the early commercialization of the region's geothermal resources. 
I. INTRODUCTION 1

II. PROGRAM PLAN SUMMARY AND BENEFITS 5

$\begin{array}{ll}\text { III. NEED FOR ENERGY } & 17\end{array}$

IV. RESOURCES 64

v. STATE BY STATE COMMERCIALIZATION PLAN 102

VI. DOE WORK DESCRIPTION 118

REGIONAL PLANNING 118

RESOURCE DEFINITION 127

TECHNOLOGY APPLICATIONS - ELECTRIC 132

TECHNOLOGY APPLICATIONS - DIRECT HEAT 135

ENVIRONMENTAL CONTROL 141

RAFT RIVER FACILITY $\cdots$

$\begin{array}{ll}\text { VII. DOE REGIONAL TEAM } & 147\end{array}$

APPENDICES:

A. GEOLOGICAL PROVINCES A-1

B. DEFINITIONS B-1 
FIGURES

PAGE

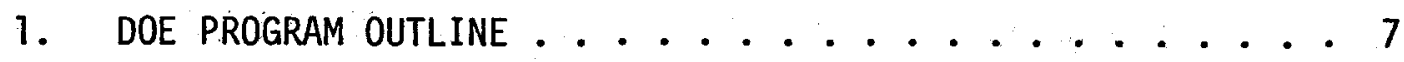

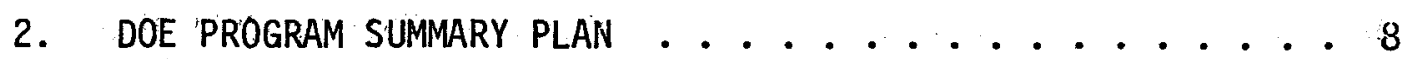

3. POWER-ON-LINE PROJECTION WITH DOE FUNDING ....... 15

4. REGIONAL BENEFITS ................... 16

5. REGIONAL ENERGY SUPPLY AND USE ........... 19

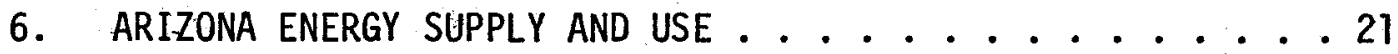

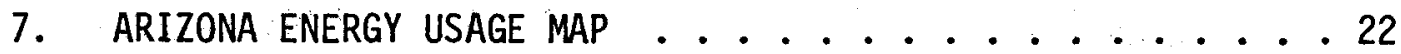

8. ARIZONA TOTAL ENERGY USE PROJECTION ......... 23

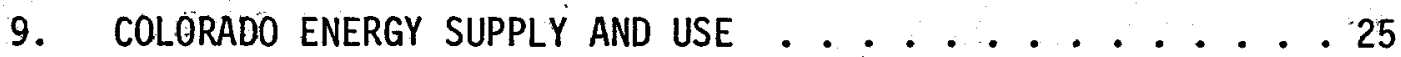

10. COLORADO ENERGY USAGE MAP .............. 26

11. COLORADO TOTAL ENERGY USE PROJECTION ......... 27

12. IDAHO ENERGY SUPPLY AND USE . . . . . . . . . . 29

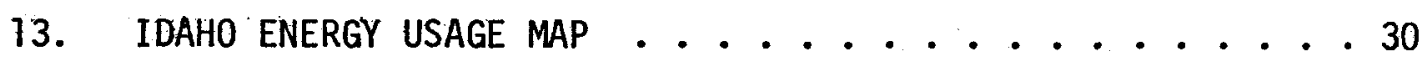

14. IDAHO TOTAL ENERGY USE PROJECTION ............... 31

15. MONTANA ENERGY SUPPLY AND USE ............. 33

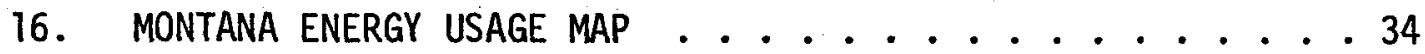

17. MONTANA TOTAL ENERGY USE PROJECTION ......... . . 35

18. NEVADA ENERGY SUPPLY AND USE ................... 37

19. NEVADA ENERGY USAGE MAP ..................... 38

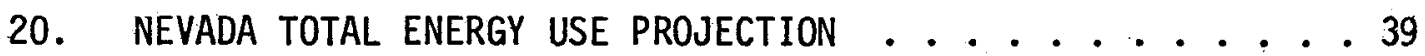

21. NEW MEXICO ENERGY SUPPLY AND USE ........... 41

22. NEW MEXICO ENERGY USAGE MAP ............. 42

23. NEW MEXICO TOTAL ENERGY USE PROJECTION ....... 43

24. NORTH DAKOTA ENERGY SUPPLY AND USE ......... 45

25. NORTH DAKOTA ENERGY USAGE MAP ........... 46

26. NORTH DAKOTA TOTAL ENERGY USE PROJECTION ....... 47

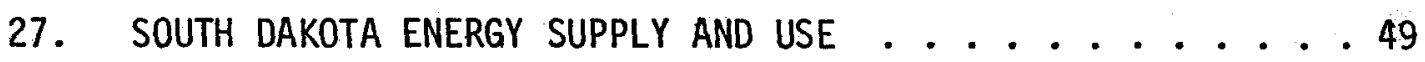

28. SOUTH DAKOTA ENERGY USAGE MAP ............. 50

29. SOUTH DAKOTA TOTAL ENERGY USE PROJECTION ........ 51

30. UTAH ENERGY SUPPLY AND USE ................... 53 
FIGURE (CONT'D)

PAGE

31. UTAH ENERGY USAGE MAP ................ 54

32. UTAH TOTAL ENERGY USE PROJECTION .......... 55

33. WYOMING ENERGY SUPPLY AND USE . . ......... 57

34. WYOMING ENERGY USAGE MAP $\ldots \ldots \ldots \ldots$

35. WYOMING TOTAL ENERGY USE PROJECTION ......... 59

36. PHYSIOGRAPHIC PROVINCES . .................. 65

37. ARIZONA HYDORTHERMAL RESOURCES $\ldots \ldots 68$

38. COLORADO HYDROTHERMAL RESOURCES .......... 72

39. IDAHO HYDROTHERMAL RESOURCES ........... 75

40. MONTANA HYDROTHERMAL RESOURCES ........... 79

41. NEVADA HYDROTHERMAL RESOURCES ................. 81

42. NEW MEXICO HYDROTHERMAL RESOURCES .......... 85

43. SOUTH DAKOTA HYDROTHERMAL RESOURCES .......... 92

44. UTAH HYDROTHERMAL RESOURCES ............. 95

45. WYOMING HYDROTHERMAL RESOURCES ................ 99

46. COVE FORT HIGH TEMPERATURE ELECTRIC PROSPECT COMMERCIALI-

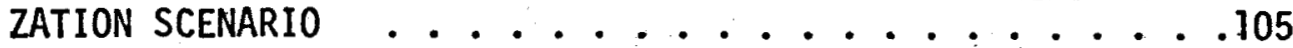

47. LEGEND FOR COVE FORT SCENARIO . . . . . . . . . . 106

48. COVE FORT PROJECTED POWER-ON-LINE . . . . . . . . . 107

49. STILLWATER/SODA LAKE MODERATE TEMPERATURE ELECTRIC PROSPECT COMMERCIALIZATION SCENARIO .......... 109

50. LEGEND FOR STILLWATER/SODA LAKE SCENARIO . . . . . . . 110

51. STILLWATER/SODA LAKE PROJECTED POWER-ON-LINE ........111

52. VALE-WEISER-ONTARIO PROSPECT COMMERCIALIZATION SCENARIO

FOR DIRECT APPLICATIONS . . . . . . . . . . . 113

53. VALE-WEISER-ONTARIO PROJECTED POWER-ON-LINE . . . . . . 114

54. SNAKE RIVER PLAIN PROSPECT COMMERCIALIZATION SCENARIO FOR DIRECT APPLICATIONS . . . . . . .............

55. LEGEND FOR SNAKE RIVER PLAIN SCENARIO . . . . ...116

56. SNAKE RIVER PLAIN PROJECTED POWER-ON-LINE . . . . . . . 117

57. DOE PROGRAM OUTLINE ......................... . . . .

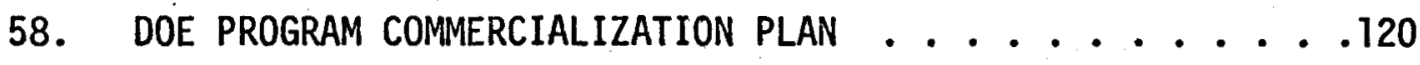

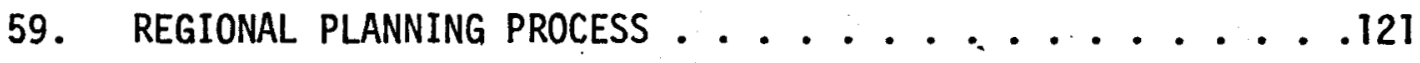

60. RAFT RIVER FACILITY SCHEDULE . . . . . . . . . 145 
I.

II.

III.

iv.

V.

VI.

VII.
HIGH GRADE ELECTRICITY GENERATION RESOURCES ... . . 3 GOALS FOR ROCKY MOUNTAIN BASIN AND RANGE REGION . . 5 BENEFIT ANALYSIS ASSUMPTIONS ........... 14 WATER TEMPERATURES IN ARIZONA WELLS ....... 67 NEWW MEXICO HIGH TEMPERATURE RESOURCE PROSPECTS . . . 88 NEW MEXICO LOW AND MODERATE TEMPERATURE RESOURCE PROSPECTS . . . . . . . . . . . . . 89 PRINCIPAL DOE REGIONAL TEAM . . . . . . . 


\section{INTRODUCTION}

The federal geothermal program focused early on technology development. The objective was the elimination of technical barriers, to help make geothermal energy cost-competitive with alternate energy sources, an objective that has been achieved for the highest-grade and most easily utilized reservoirs.

Over the past two years, the federal approach toward stimulating geothermal energy resource development has shifted from a program of many independent research and development projects that have successfully provided the basic technology for resource extraction and utilization, to a mission-oriented program aimed at accelerating the commerical utilization of geothermal resources. This mission-oriented approach includes sequential planning, implementation, and monitoring of the interrelated activities (both technical and nontechnicai) that are needed to produce electricity and to utilize direct heat in commercial quantities.

To form a basis for this approach, researchers have estimated the potential for commercial utilization. They assessed available resources, industry activity, and the need for technological or institutional initiatives at all levels. These individuals constructed scenarios which, together with estimates of the potential contribution of new discoveries, provide both a plan of attack and a realistic estimate of the achievable levels of utilization.

As this program plan details, the region contains unusually abundant geothermal resources. Though they cannot be developed, a large drysteam system and several very high-temperature liquid-dominated hydrothermal systems are situated in Yellowstone Park. Several very highgrade reservoirs (reference Appendix B) are located in other states within the region, and geological extrapolation indicates that ten to twenty such reservoirs have yet to be discovered. These systems can 
provide cost-competitive electrical power under current economic and technological conditions. Following Greider [1] in notation, we estimate the proven, potential, and inferred reserves for reservoirs with temperatures in excess of $200^{\circ} \mathrm{C}$ to be as shown in Table $\mathrm{I}$.

As hydrothermal reservoirs of lower and lower temperature are identified, their number goes up very rapidly, approximating a log-normal distribution. Consequently, a much larger number and wider distribution of medium- to high-grade $\left(\mathrm{T}>150^{\circ}<200^{\circ} \mathrm{C}\right)$ hydrothermal reservoirs may be expected to be found that could provide cost competitive electrical power with improved technology and rising fossil fuel costs. Once the economicaliy competitive temperature is lowered to $150^{\circ} \mathrm{C}$, electrical power production will increase by about a factor of four over the $200^{\circ} \mathrm{C}$ resources, yielding approximately 30,000 to 40,000 MWe.

By the same token, utilization of the extremely widespread low- to medium-grade $\left(30^{\circ} \mathrm{C}<\mathrm{T}<150^{\circ} \mathrm{C}\right)$ reservoirs may ultimately have the greatest regional and national effect, through direct-heat applications that will displace substantial amounts of fossil fuel.

The program to achieve these results is detailed in the following chapters. Many of the federal initiatives are incentives to cause industry, the states, and local communities to act. Industries and organizations are often reluctant to use an unfamiliar resource, but it's a fact: hydrothermal resources in this region are ready for use.

\section{REFERENCES}

[1] B. Greider, Geotherma1 Potential 1978, Intercontinental Energy Corporation. 
Table I

High Grade Electricity Generation Resources

(for 30 years)

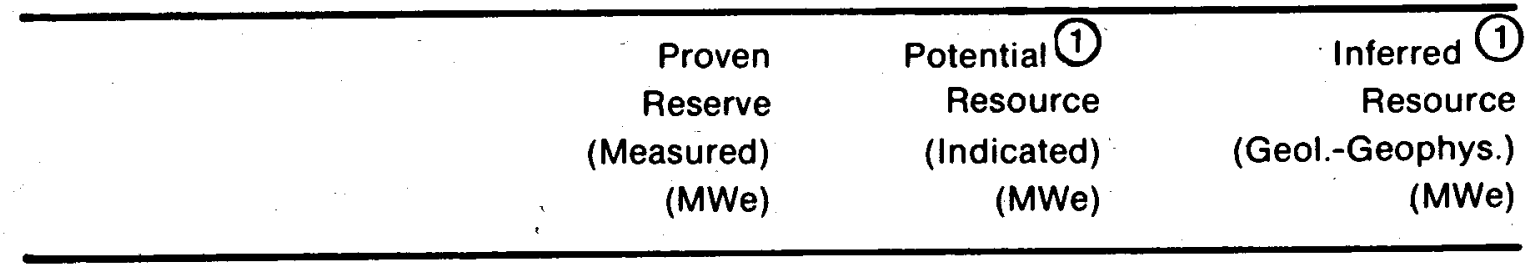

Utah

Roosevelt Hot Springs

100

200

200

Cove Fort

500

1000

Sulphurdale

Black Rock Desert

Thermo

Nevada

Battle Mountain Heat

1000

2500

Flow High

New Mexico

Valles Caldera

50

Other Rio Grande Rift and

Lightning Dock

Idaho

Eastern Snake River Plain

Subtotals

150

2250

5600

Total

$8000 \mathrm{MWe}$ (2)

(1) See appendix B

(2) Undiscovered high grade reservoirs throughout the region may contribute an additional $8000 \mathrm{MW}$ 


\section{PROGRAM PLAN SUMMARY AND BENEFITS}

\section{MISSION STATEMENT}

The mission of the Rocky Mountain Basin and Range program is to stimulate the regional development of hydrothermal resources in an economic, reliable, operationally safe, and environmentally acceptable manner. In cooperation with federal agencies, state and local governments, private industry, and special-interest groups, initiatives will be implemented to bring about the commercial utilization of hydrothermal energy for electrical power generation and direct heat application. The goal is to achieve the levels indicated in Table II.

\section{STRATEGY}

If the regional goals are to be met, then industry must make a very substantial investment (eight billion 1978 dollars to reach the goals set for the next twenty years). As a result, the primary thrust of the program is to offer incentives to stimulate this investment. Regional incentives range from direct financial assistance through cost-sharing, to informational incentives such as user assistance and technology transfer. The regional management also supports national incentives such as loan guarantees, intangible drilling costs, depletion allowances, and investment tax credits. For hydrothermal energy to compete successfully in the region, it must enjoy appropriate legal, institutional, regulatory, and financial treatment. This imposes an educational responsibility on the program at federal, state, and local levels.

The program shares, with the DOE Division of Biomedical and Environmental Research, a responsibility to ensure the environmental soundness of hydrothermal development. A strategy of pre-development baseline studies, followed by long-term monitoring of environmental and safety effects of major developments, will satisfy this need. 
Table If

Goals for RMB\&R Region

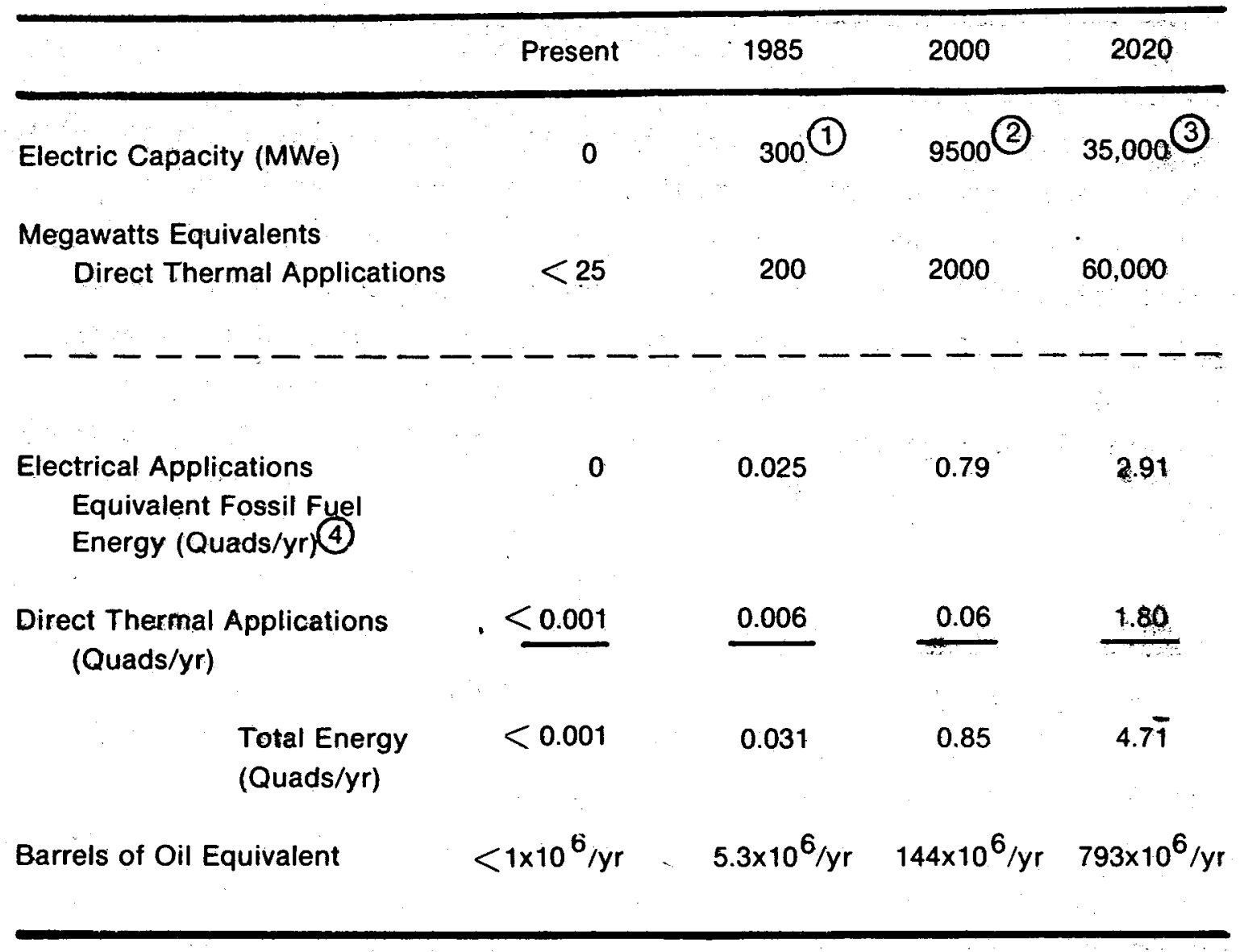

(1) Assuming additional. $150 \mathrm{MW}$ of proven reserves established by 1980 .

(2) Assuming commercialization of $8000 \mathrm{MW}$ of proven, potential and inferred resources and $1500 \mathrm{MW}$ of high grade undiscovered resources.

(3) Assuming the economically competitive reservoir temperature is lowered to $150^{\circ} \mathrm{C}$.

(4) See Appendix B. 
Application of new technology will be employed to lower the economically competitive temperature of reservoirs, thereby multiplying the potential application of hydrothermal energy in the region.

\section{PROGRAM WORK ELEMENTS}

There are six major elements that encompass the activities of this program. They are Regional Planning; Resource Definition; Technology Application - Electric; Technology Applications - Direct Heat; Environmental Control; and the Raft River Facility. These elements which are briefly discussed below are shown in Figure 1. Figure 2 depicts relative levels of activity and illustrates schedules for the activities.

\section{Regional Planning}

Regional planning provides for analysis of the economic, environmental, institutional, legal, and technological framework within which regional development of hydrothermal energy must take place. It also provides for the identification of technical and nontechnical federal initiatives that will stimulate hydrothermal development by private industry.

The principal activity of this program component is the formulation of realistic state commercialization plans, an analysis of which will reveal the critical-path items that require federal support if timely development is to take place. Assessment of special regional problems that affect hydrothermal commercialization, such as water availability, will also be an important part of this regional planning.

Educationa1 programs will be initiated for state officials, regulators, utility executives, and especially state industrial development commissions. These programs will encourage the public to accept hydrothermal commercialization and encourage individual states to attract industry to their hydrothermal resources. 


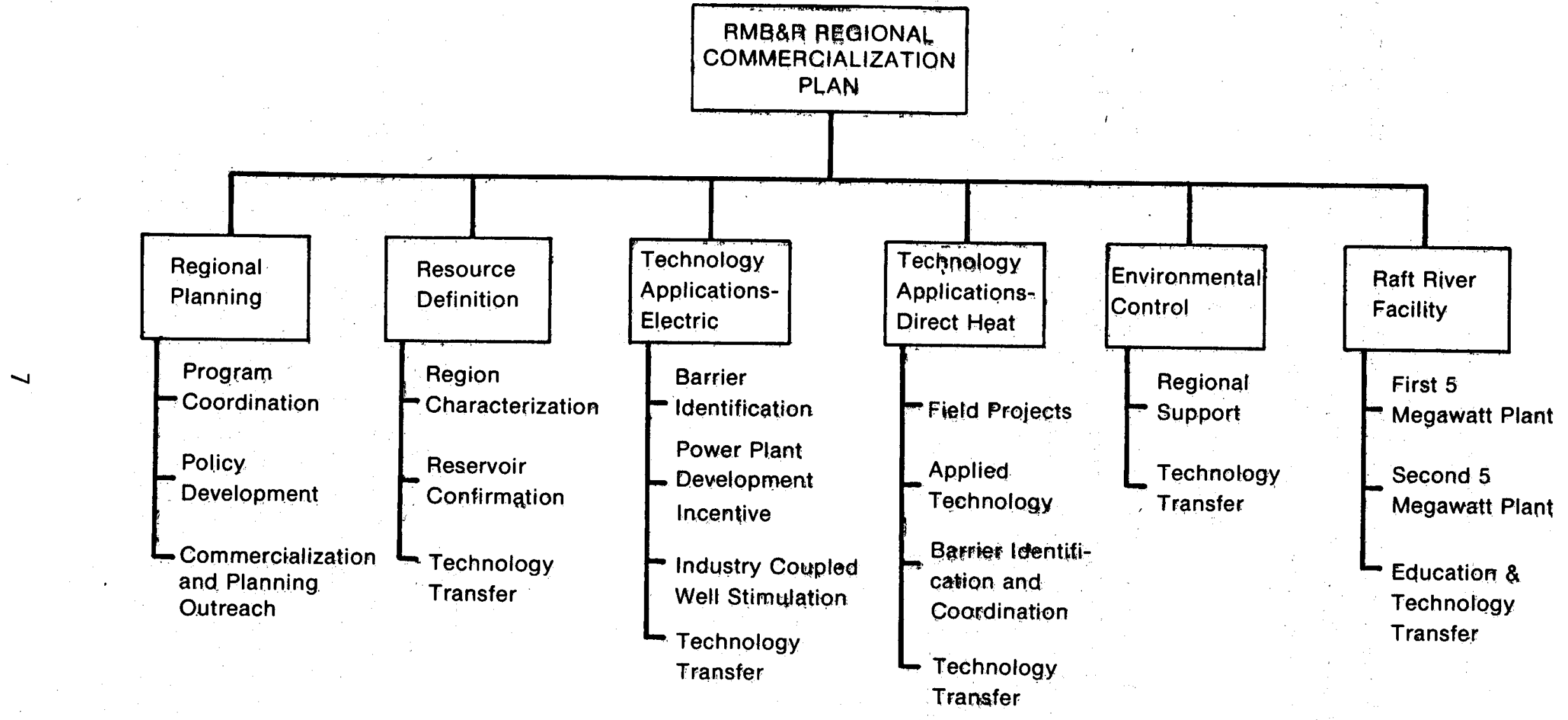

Fig. I DOE program outine.

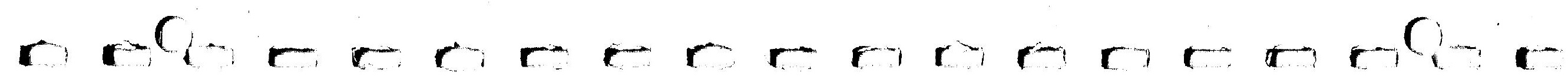




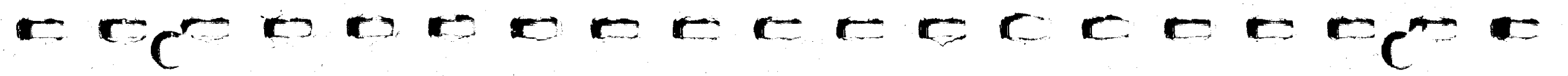

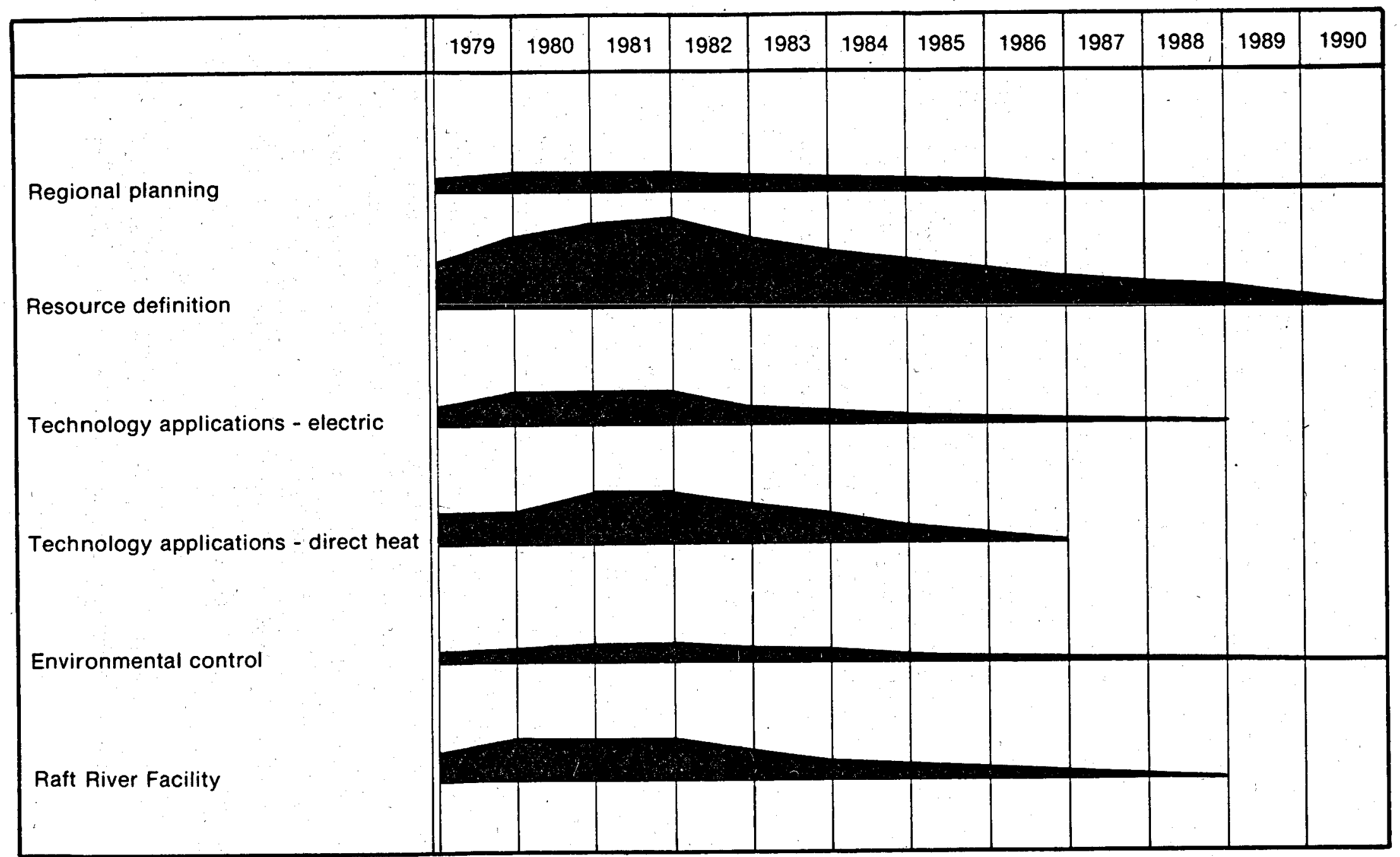

Fig. 2 DOE program summary plan. 


\section{Resource Definition}

Resource definition will be the major federal thrust within the region, not only because uncertainty about the reservoirs is a major barrier to hydrothermal development, but also because of the high front-end cost associated with reservoir confirmation.

The cornerstone of this program component is the Industry-Coupled Case Study Program. The government should share the costs of expensive exploration and reservoir-confirmation driling, because utilities will not build a power plant until a reservoir's ability to deliver fluids for a known lifetime can be established. Governmental sharing of these high front-end costs may substantially reduce the economically competitive temperature of reservoirs. This program will also provide vital knowledge about the region's different resource types, which will be dissentinatêd to the rest of the industry. By reducing uncertainty and risk, this information should stimulate resource development.

Another major portion of the resource-definition effort is aimed at the low- and moderate-temperature resources that abound in the region. Major energy companies have generally shown little interést in such lower-grade resources, because of a natural focus on electrical power generation. ConsequentTy, the states and the U.S. Geological Survey are cooperating with the Department of Energy in a low-temperature reservoirassessment program, and the state-coupled program that is identifying those areas in each state where low-temperature resources are located near potential users of direct heat. The initial inventory is resulting in state-by-state resource maps, the first of which has already been published in preliminary form. This initial inventory is being followed by individual prospect confirmation.

Although hot springs, gas vents, or deposits of dissolved solids, reveal the presence of many reservoirs, the majority lack any surface expression. 
The reservoirs that will supply future power plants and direct heat applications must be located now, and confirmation efforts will be necessary if we are to meet near-term goals. Locating new resources will boost the confidence of state and local officials and industry representatives, encouraging them to make the commitments that are now so necessary. Consequently, a program of regional heat-flow mapping and lava-flow dating will be initiated. Both heat-flow anomalies and indications of recent volcanic activity will help target hidden resources.

\section{Technology Applications}

Generic technology development will be directed by the Geothermal Technology Development Program under the Department of Energy's Assistant Secretary for Energy Technology (ET). Applications of new technology in the region will, however, be sponsored under this program.

One major part of this program component is the encouragement of directheat applications through the support of direct application experiments (the PON program) which are, in effect, cost-sharing demonstrations. A large direct heat application potential exists in every state in the region, and results of early experiments should promote a great deal of interest. Because low-temperature resources are widespread, a very vigorous program is warranted through $i 983$.

This program component is also designed to encourage the production of electrical power from high-grade reservoirs in the region. The identification of such reservoirs, as part of the resource-definition program component, is typically in itself not sufficient to foster their development and utilization. The resource developer, the utility, and often, an intermediate risk-taker must a 11 be brought together to make electrical power production possible. The purpose of this element is to develop and pursue new catalytic initiatives that will make this possible. 
High-grade reservoirs with electrical potential have one technological problem in common: expensive wells can be poor producers. Wellstimulation techniques developed under the ET Geothermal Technology Development Program will be applied in the region beginning in fiscal year 1980. An Industry-Coupled Well Stimulation Program will foster the use of new stimulation techniques to reduce well-failure rates and power costs.

\section{Environmental Control}

In addition to Environmental Impact Assessment/Environmental Impact Statement (EIA/EIS) support, Program Opportunity Notices/Program Research and Development Announcements (PON/PRDA) review, and regional and institutional activites, a program of subregional environmental data gathering and site-specific monitoring will be expanded in 1980. In particular, air quality, meteorology, seismicity, subsidence, water quality, ecology, soils, geology, hydrology, demography, socioeconomics, history, archaeology, and resource-use will be investigated for each subregion. Preplans will be prepared to identify what is necessary to complete the baseline environmental data to adequately prepare any EIA/EIS documents.

\section{Raft River Facility}

Medium- and low-temperature hydrothermal reservoirs are much more common than high-temperature reservoirs. Thus, to the extent that lower temperature reservoirs can produce economical electrical power, the potential of hydrothermal energy will greatly increase. The facility at Raft River is designed to test the economics of utilizing a moderatetemperature $\left(150^{\circ} \mathrm{C}\right)$ reservoir. The first $5 \mathrm{MW}$ thermal loop is now under construction and will test the economics of conventional hardware to provide baseline data. The second 5MW thermal loop on which construction is planned to start in 1980, will be a test bed for advanced technology 
applications (such as for the direct-contact heat exchanger developed under the ET Geothermal Technology Development Program).

These two loops will be run side-by-side to evaluate competing utilization technologies and, assuming success, they will serve as showcases for technology transfer.

The Raft River Facility will be used to evaluate direct applications of moderate temperature geothermal resources. Experiments will be conducted in grain drying, farming, processing and aquaculture. Industry will be invited to participate and review results of the experiments. The public will be made aware of the many uses for hydrothermal energy by an active program of tours and lectures at the Raft River Facility. 


\section{BENEFIT ANALYSIS}

The benefits from the development of the hydrothermal resource in the Rocky Mountain Basin and Range Region are varied and important. Development could mean employment-level increases, industrial growth, energy independence, balance-of-payment advantages, additional tax revenues, capital investments, and an improved environment. The federal, state, and local governments will derive fiscal benefits if the hydrothermal resource is effectively developed. Using reasonable assumptions, it is estimated that the return of revenues through income taxes and federal royalties will approach $\$ 5.1$ billion by the year 2000 if the regional goals are met. Cumulative income to the federal budget will be in the order of $\$ 35$ billion by the year 2000. The accompanying tax revenue to the state and local governments in the region is estimated to be $\$ 28$ million in the year 1985, $\$ 340$ million in the year 1995 , and $\$ 638$ million in the year 2000 - for a cumulative total of $\$ 4.3$ billion through the year 2000 .

To receive this level of financial benefit, industry must make significant capital investments. By $1985, \$ 360$ million will be required, $\$ 1.9$ billion will be by 1990, $\$ 4.4$ billion by 1995 , and $\$ 3.2$ billion by 2000 .

Displacing the use of oil and gas with hydrothermal energy will be of great benefit: about 1 billion barrels of oil could be displaced through the year 2000. At today's oil prices of about $\$ 12$ per barrel, this would mean a total balance-of-payment advantage in excess of $\$ 11$ billion.

Table III identifies the assumptions that were made for this benefit analysis. The estimates of power-on-line from which the above calculations were developed are shown in Figure 3. Figure 4 graphically illustrates the regional benefits data. 
Table III

Benefit Analysis Assumptions

- Barrel of oil costs $\$ 12.00$

- No inflation on projections

- Electric power rate $\approx 30 \mathrm{mils} / \mathrm{kWhr}$

- Liquid and gas fuel $\approx \$ 3.00 / \mathrm{MBtu}$

Investment capital is $\$ 715 / \mathrm{kW}$ installed capacity

- $1 \mathrm{MW}$ of geothermal energy on-line equals

5,100 barrels of oil/yr for direct applications, 14,200 barrels of oil/yr for electric applications

- $48 \%$ federal taxation

- $10 \%$ federal royalty payment 


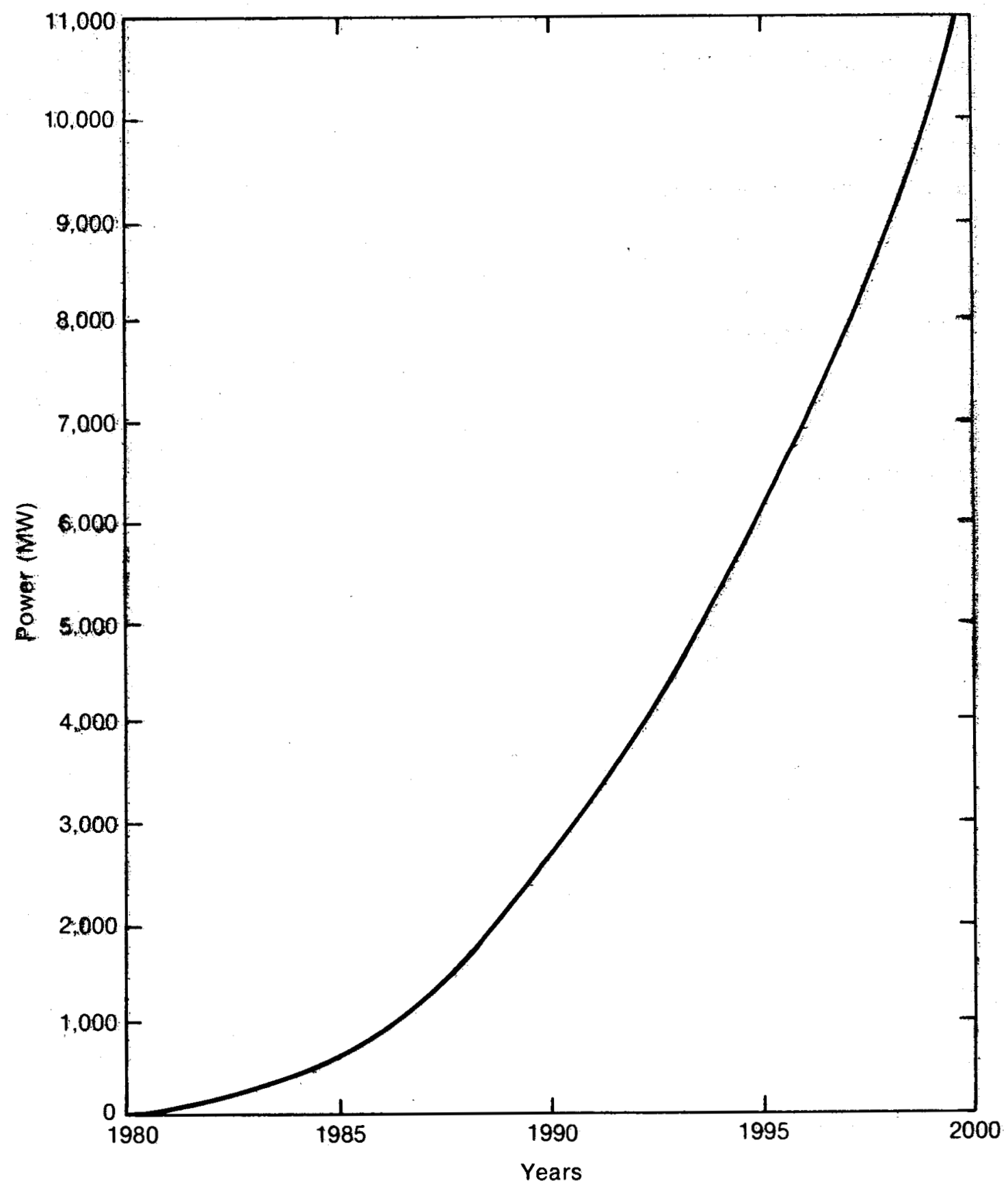

Fig 3. Power on line projections with DOE funding. 


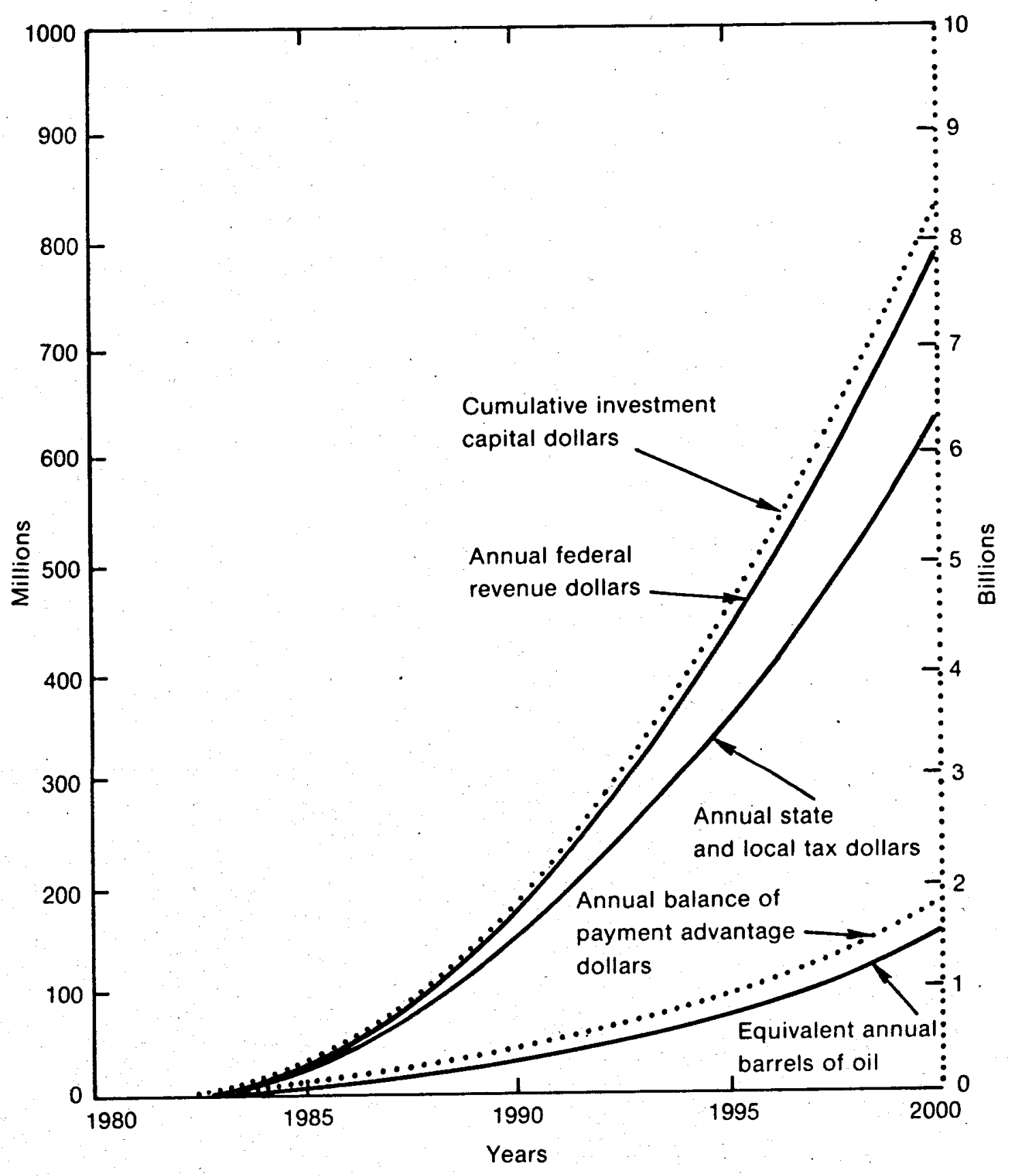

Fig. 4 Regional benefits. 


\section{NEED FOR ENERGY}

A preliminary review of the energy supply and demand for each of the states in the Rocky Mountain Basin and Range Region has been completed. Various state agencies furnished reports for the respective states, [1-50] and this section of the regional plan summarizes the information for the region, as well as for the particular states. A more detailed compilation of energy supply-and-demand data is being prepared by the operations Research contractor in each state, in conjunction with the site-specific commercialization plans.

This section discusses energy supplies (sources of fuel) for the region and for each state. Regional and state energy consumption is also described. Electricity is treated only as an intermediate step since the amount of electricity produced in each state relates directly to the types of fuel used to generate the electricity.

A map for each state indicates how much energy is used in each community. A comparison of these maps with the corresponding resource maps in Section IV will show how close hydrothermal resources are to areas of energy demand. The power usage numbers shown on the maps are times $10^{12}$ BTU per year. Values are not shown for communities where energy usage is less than $.1 \times 10^{12}$ BTU per year.

Projections of state energy demands have also been provided where possible. To correlate the information from different reports, all demand projections have been extrapolated to the year 2000. These projections are not predictions; they are extensions of apparent trends. Continuing research will provide additional demand-projection data. 


\section{REGIONAL SUMMARY}

The region is a net energy exporter (see Figure 5). The region exports approximately 70 to $75 \%$ of the energy it produces, if uranium is included, and about $40 \%$ if uranium is not considered a supply. The industrial sector is the leading consumer of energy in the region. Natural gas is the primary energy source for industry, accounting for about $45 \%$ of the supply. $0 i 1$ supplies about $33 \%$ of the industrial needs. Coal is used primarily for the generation of electricity.

Although it varies from state to state, major industrial consumers in the region use low- to intermediate-heat energy sources for at least a part of their energy needs. These industries include food and kindred iproducts; wood and lumber products; and stone, c1ay, and glass products. In some of the states, mining is a major consumer of the energy derived from electricity, natural gas, and diesel fuel.

Transportation primarily uses $0 i 1$ and a smal1 quantity of natural gas. It is the second largest energy-consuming sector in the region, and it is included in this section only to give a total view of energy consumption.

The population centers vary greatly in size, Tatitute, and altitute. These are factors that have a direct bearing on the amount of energy required for space conditioning in the residential and commercial sectors. The percentage of energy that these sectors consume for space conditioning and for water heating varies a great deal, but is in the range of 50 to $95 \%$. 
Enërgy Supply

$\left(11,021.1 \times 10^{12}\right.$ Bt u's, $60 \%$ exported)

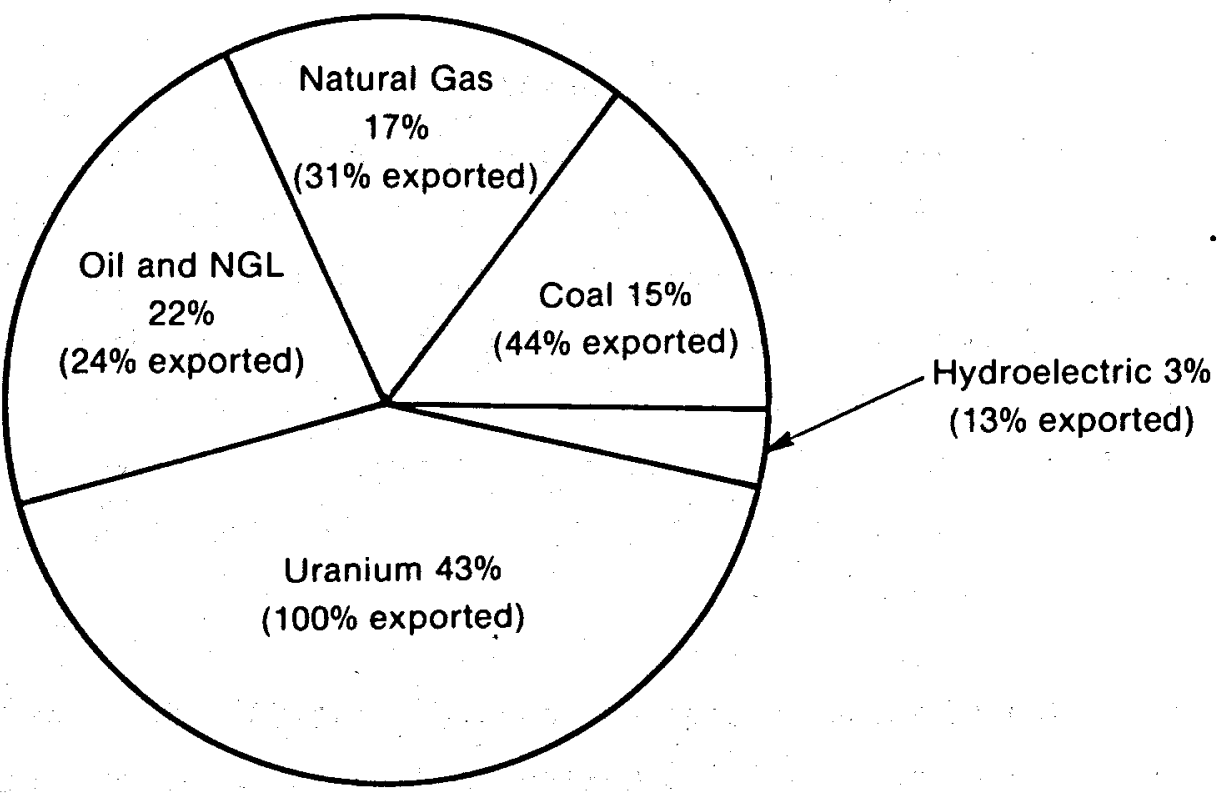

Energy Use

(4132.7 × 10 12 Btu's)

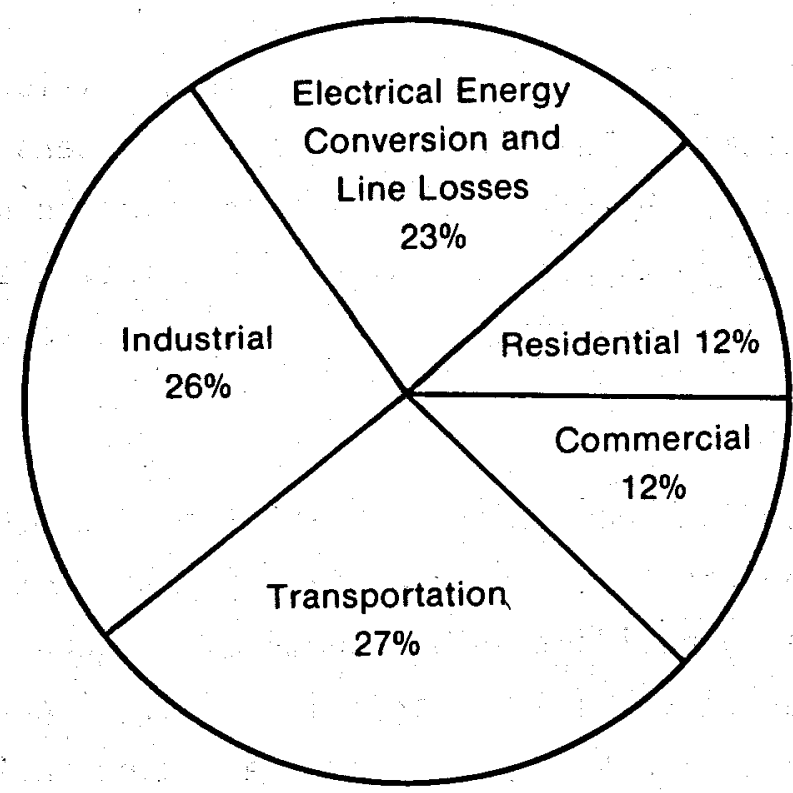

Fig. 5 Regional energy supply and use. 


\section{STATE OF ARIZONA ENERGY SUMMARY}

One of the most significant factors in Arizona's pattern of energy consumption and supply is the large portion of the net energy Arizona must import (Figure 6). Transportation is the largest energy-consuming sector in Arizona; however, the industrial sector does require about as much as the residential and commercial sectors combined. Natural gas, almost all of which is imported, is the major source of energy used in the residential, commercial, and industrial sectors of Arizona's economy. Figure 7 is a map that approximates the amount of energy used by communities throughout the state.

The primary metals industries consume about $50 \%$ of the industrial energy needs; however, industries making food and kindred products, lumber and wood products, chemicals and allied products, and stone, clay and glass products account for about $25 \%$ of the industrial energy consumption. Growing industries should require an additional 88.2 trillion BTUs by 1985. Arizona's energy use is shown in Figure 6.

Due to the wide range of climates in Arizona, air conditioning is as necessary as space heating. The larger population centers are located in the warmer sections of the state, and air conditioning uses more energy than space heating. Space-conditioning requirements amount to approximately $50 \%$ of the residential and commercial sectors' energy needs.

The state's population is expected to increase from 2,212,000 in 1975 to $3,391,000$ in 1985, indicating a large increase in a 11 sectors of energy demand. The increase in residential and commercial energy demands from 1975 to 1985 is projected to be 318.7 trillion BTUs. Figure 8 shows the energy-demand projection for the state. As the figure indicates, Arizona's energy-demand should more than double by the end of this century. 
Energy Supply

(687.2 $\times 10^{12}$ Btu's - $11 \%$ exported, $66 \%$ imported)

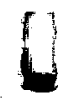

1

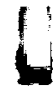

1

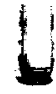
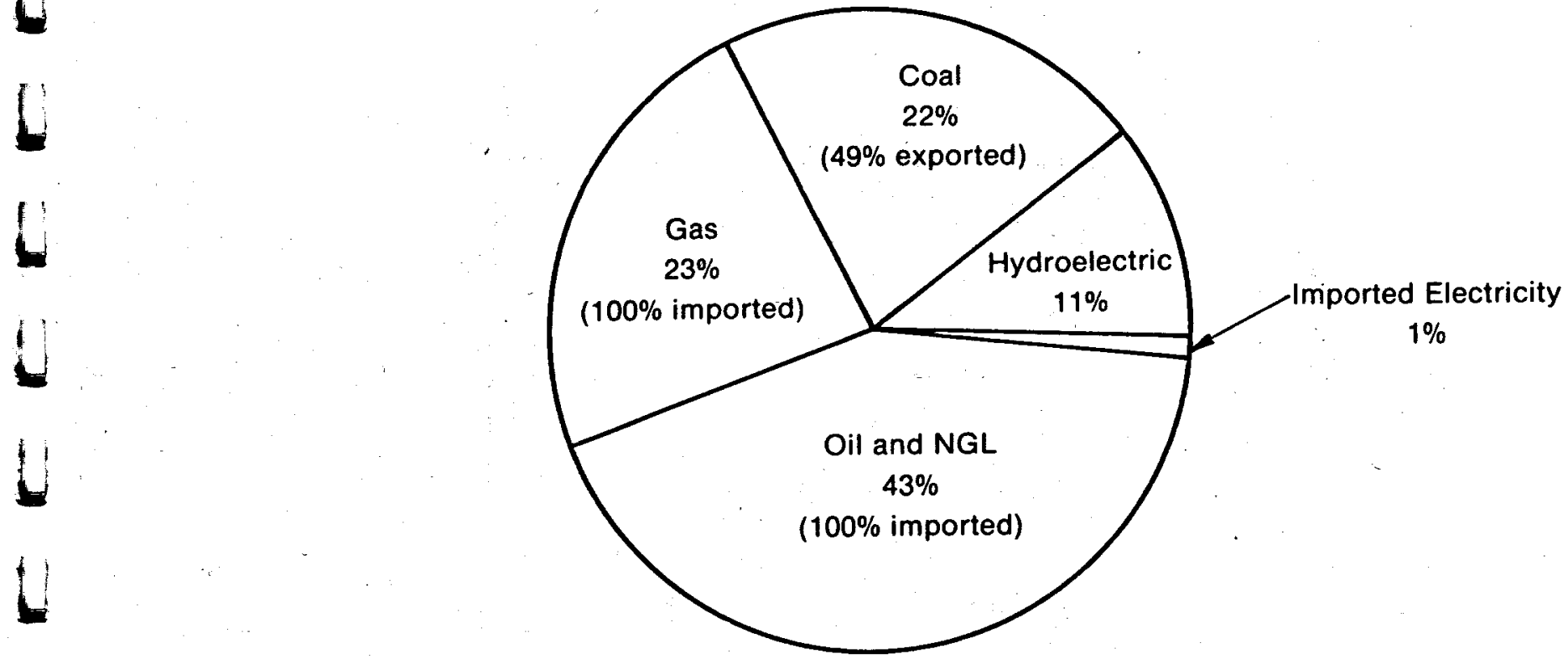

Energy Use
$\left(625.6 \times 10^{12}\right.$ Bt u's)

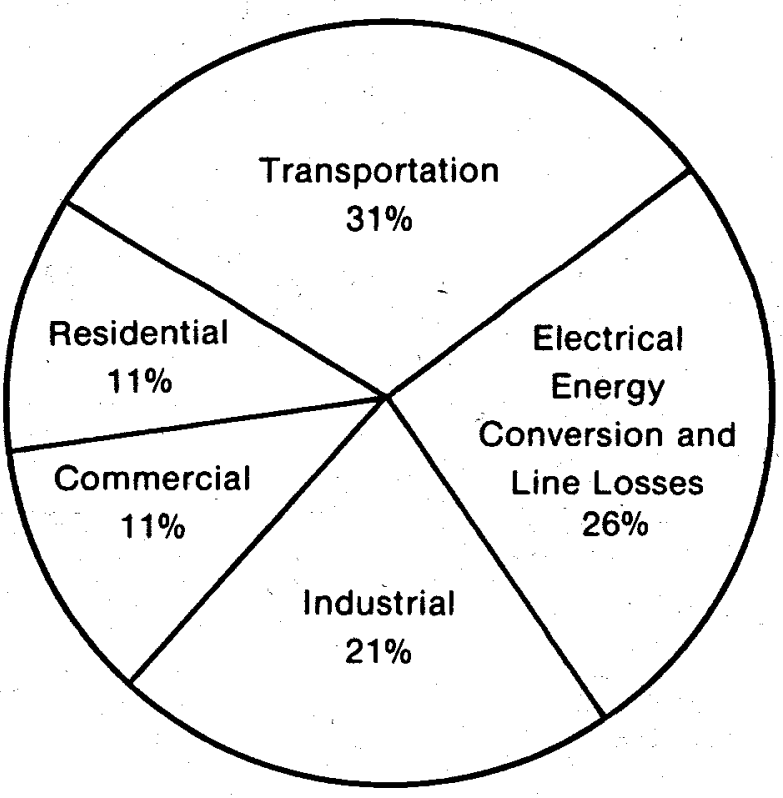

Fig. 6 Arizona energy supply and use. 


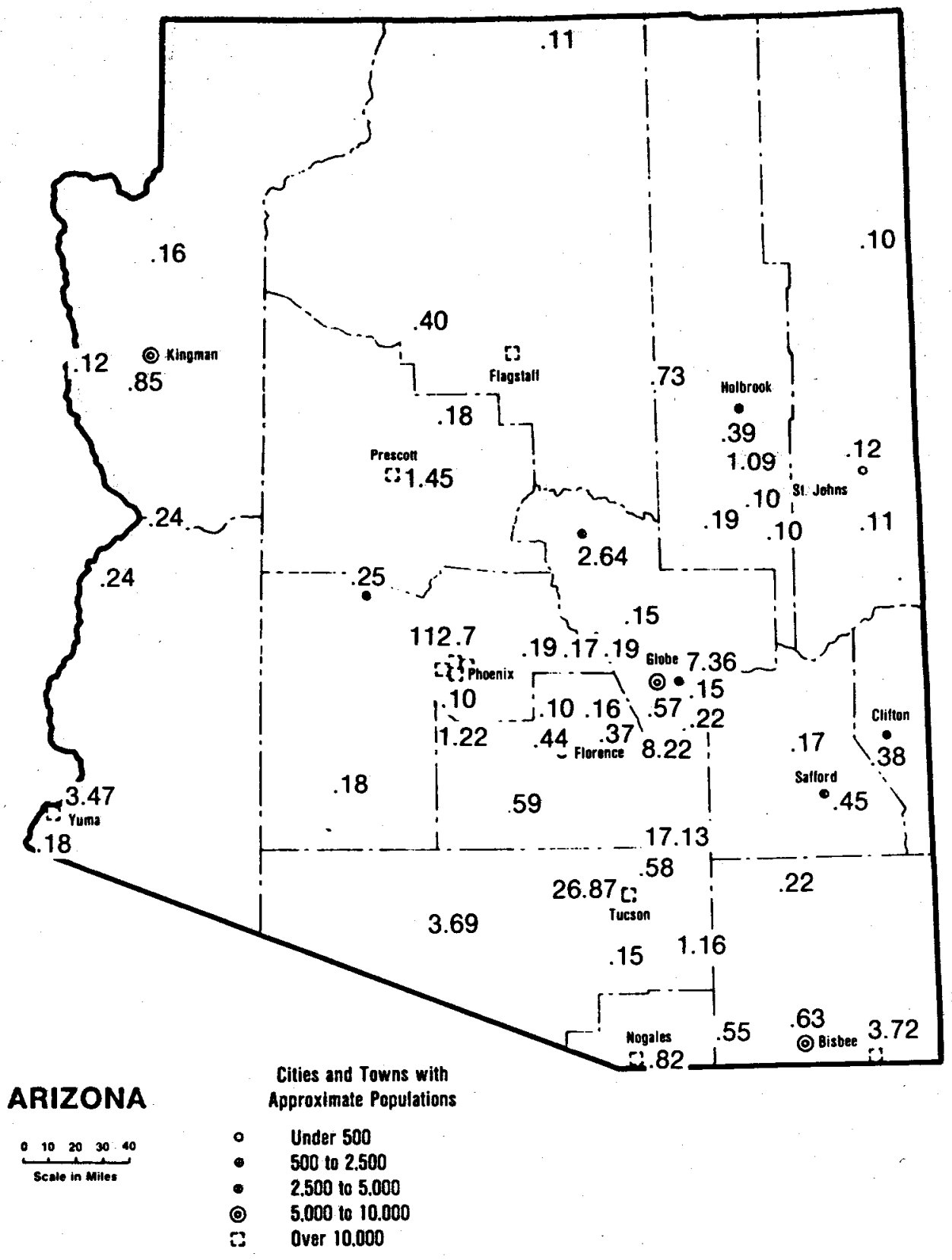

Fig. 7 Arizona energy usage map. 


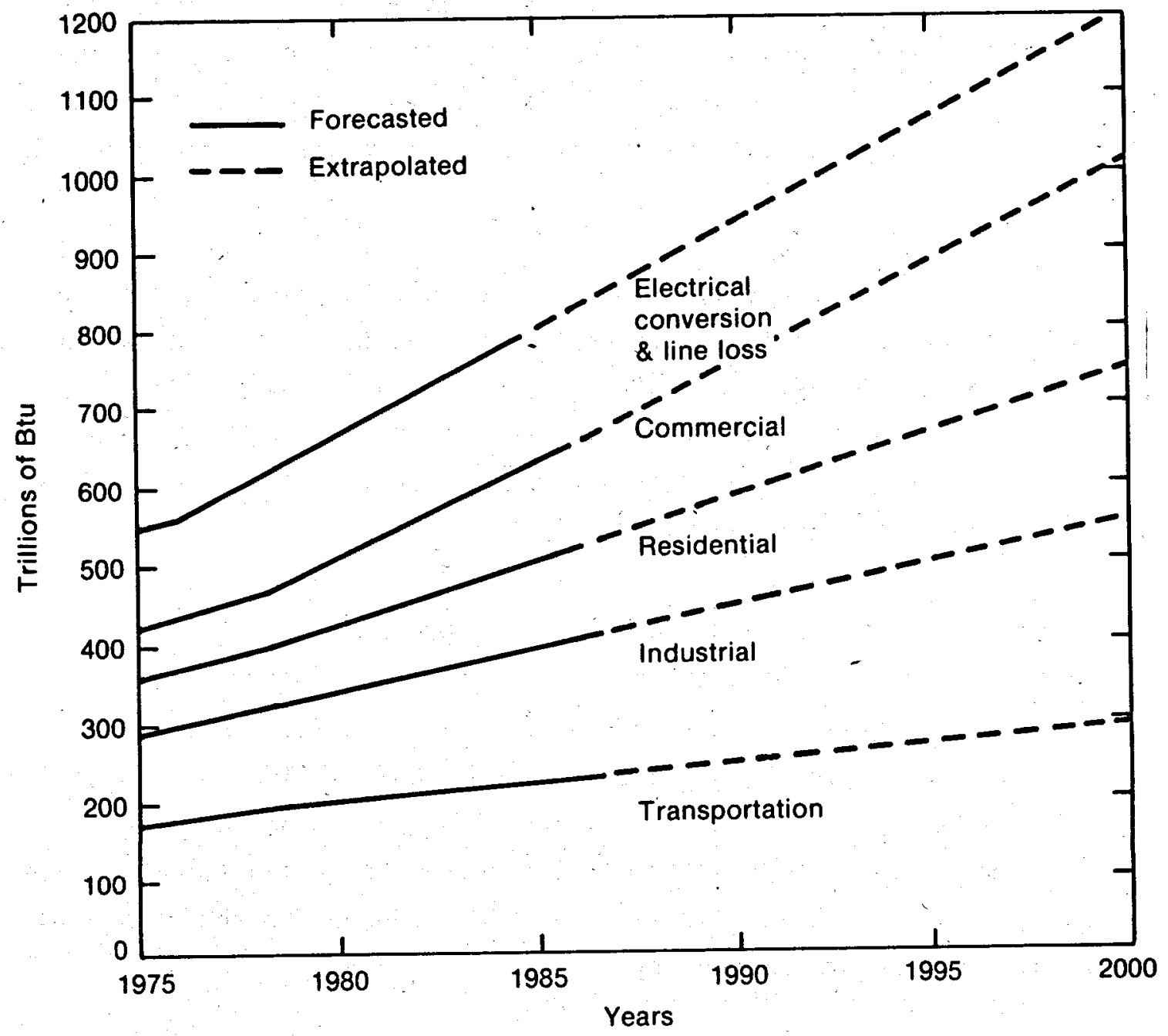

1

Fig. 8 Arizona total energy use projection. 


\section{STATE OF COLORADO ENERGY SUMMARY}

A significant factor in Colorado's net energy supply and consumption picture is the fact that the state exports a large quantity of uranium (see Fjgure 9). If uranium were not considered, however, Colorado would be a net importer of energy. It imports about $50 \%$ of its natural gas, the 1 argest source of energy used in the residential, commercial, and industrial sectors, and about $28 \%$ of its oil, a major source for industry. Figure 10 is a map that provides estimates by communities throughout the state.

The industrial sector in Colorado is second only to transportation in energy consumption, and is the largest in the region. $0 i 1$ and natura 1 gas supply about $80 \%$ of Colorado's industrial energy needs. The food industry is the largest industrial consumer ( $~ 30 \%$ of the industrial tota 1); other industries that can use low- to intermediate-temperature energy account for about another $20 \%$.

When the residential and commercial sectors are combined, they account for a large portion of Colorado's natural gas consumption. Approximately $70 \%$ of the residential consumption is for space conditioning. Colorado's population is expected to increase from about 2.7 million in 1976 to about 3.2 million in 1985, thereby increasing the demand for energy in all sectors. Figure 11 projects total energy consumption for the state. An average growth rate is assumed; Colorado's demand for energy should double by the turn of the century. 


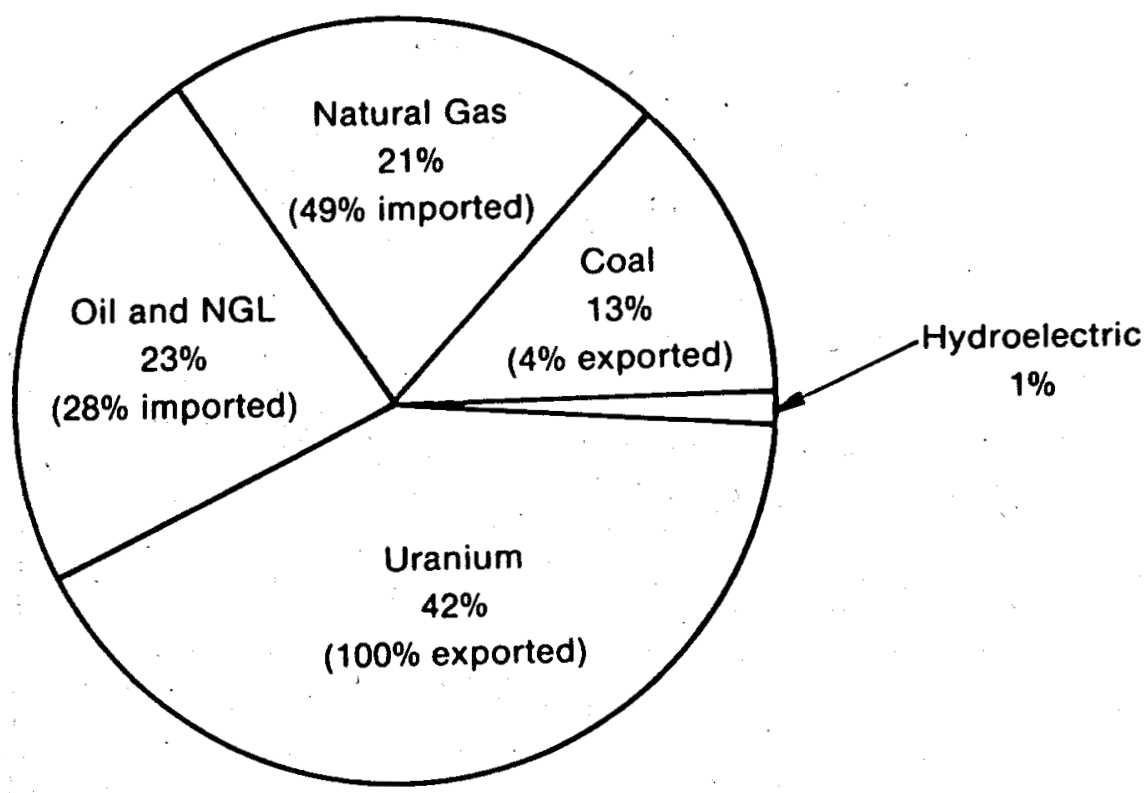

\section{Energy Use \\ (839.2 $\times 10^{12}$ Btu's)}

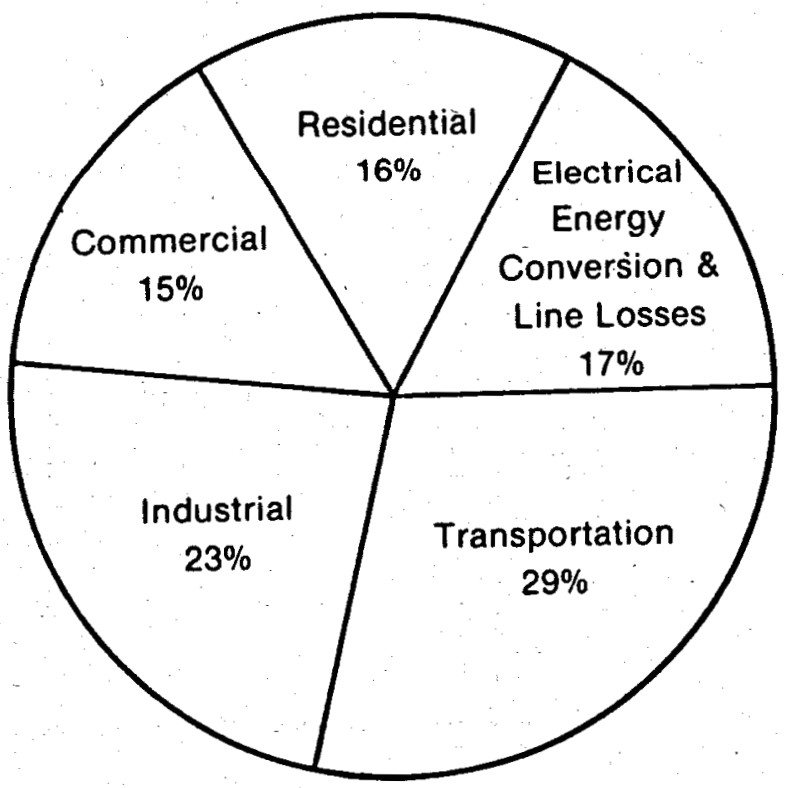

Fig. 9 Colorado Energy Supply and Use. 

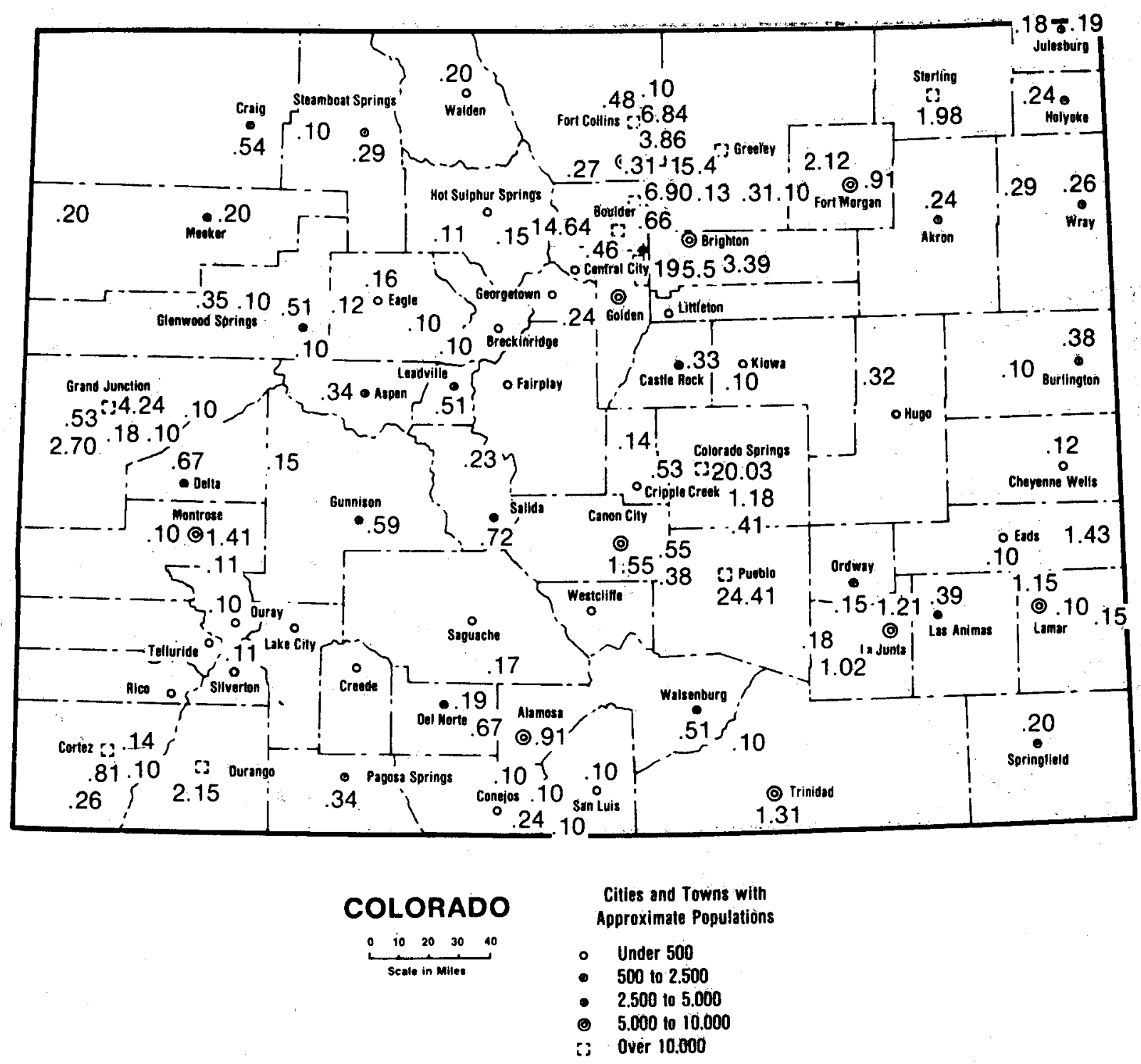

Fig. 10 Colorado energy usage map. 


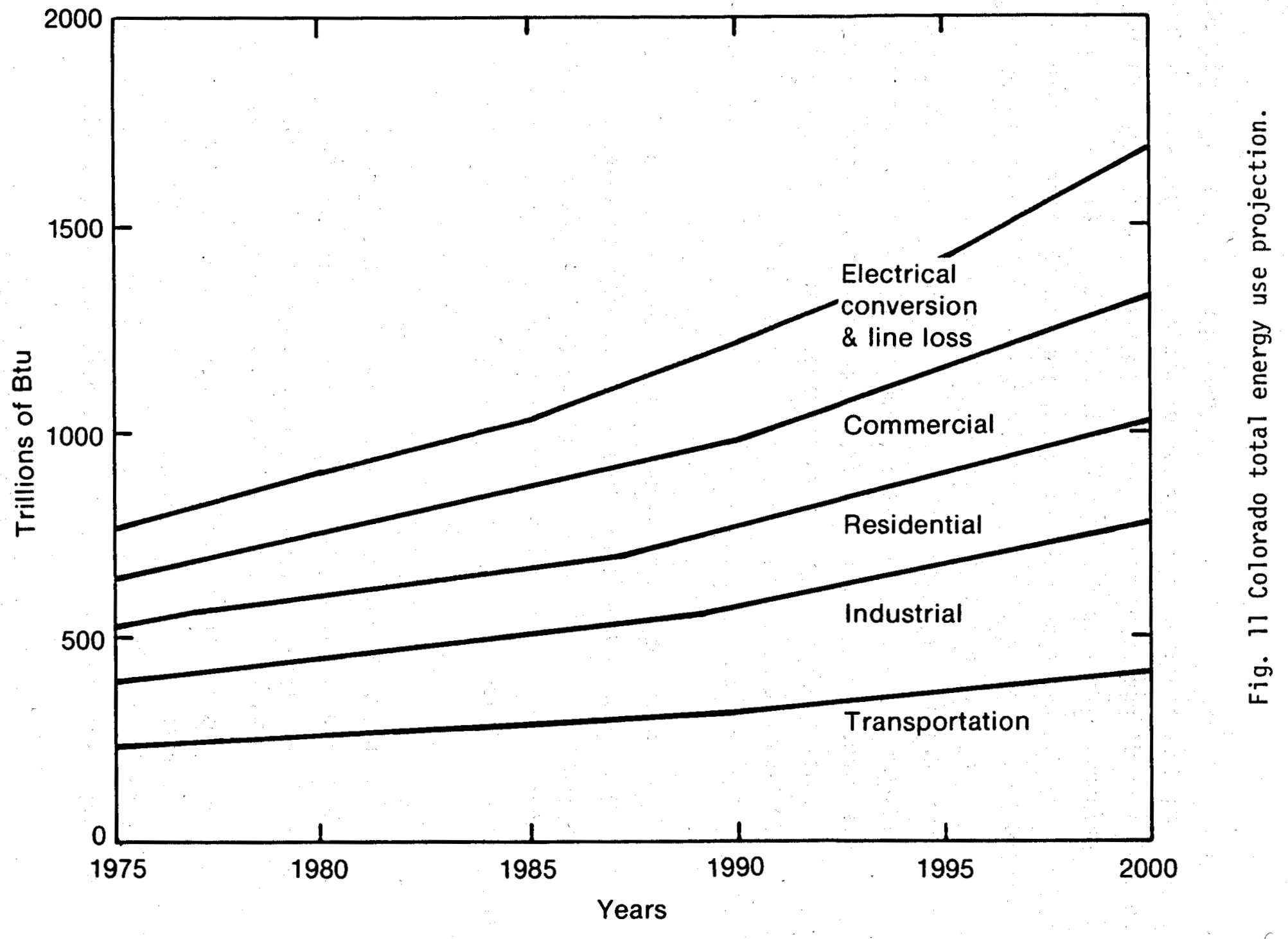

$\approx$

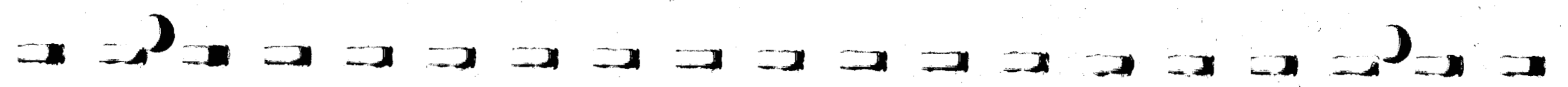




\section{STATE OF IDAHO ENERGY SUMMARY}

The most significant energy factor in Idaho is that the state imports a large fraction of net energy (Figure 12). Natural gas is the primary energy source used by Idaho's industries ( $~ 40 \%$ of the state's industrial needs). $0 i 1$ and electricity supply about $25 \%$ each, and coal the remaining $10 \%$. $0 i 1$ is the major source of energy for the residential and commercial sectors, supplying approximately $40 \%$ of those energy needs. Electricity and natural gas make up the majority of the remainder, with coal supplying only a very small fraction. Community energy use is distributed approximately as shown in Figure 13.

The industrial sector is the largest energy user in Idaho. The food and kindred products and the wood and lumber products industries account for approximately $45 \%$ of this industrial energy consumption. Studies have shown that a large portion of these industries energy needs could be satisfied by low- to intermediate-temperature sources of energy.

The residential and commercial sectors combined use more energy than the industrial sector. $0 i 1$, natural gas, and electricity are the major sources of energy for these sectors. Residential space heating (80\%) and water heating $(10 \%)$ account for approximately $90 \%$ of the residential energy consumption, and the commercial sector probably consumes energy according to a similar pattern. The state population is expected to increase from the present 830,000 to about $1,000,000$ in 1985, and to $1,243,000$ in 2000. If the state experiences a moderate rate of growth in the near future, energy demand will increase as shown in Figure 14. Assuming a moderate growth rate, Idaho's energy demand is expected to double by 2010. The initial dip in the projected demand is an effect of possible near-term curtailments in natural gas supplies, and the conservation efforts that would result. 
( $314.7 \times 10^{12}$ Btu's - 66\% imported)

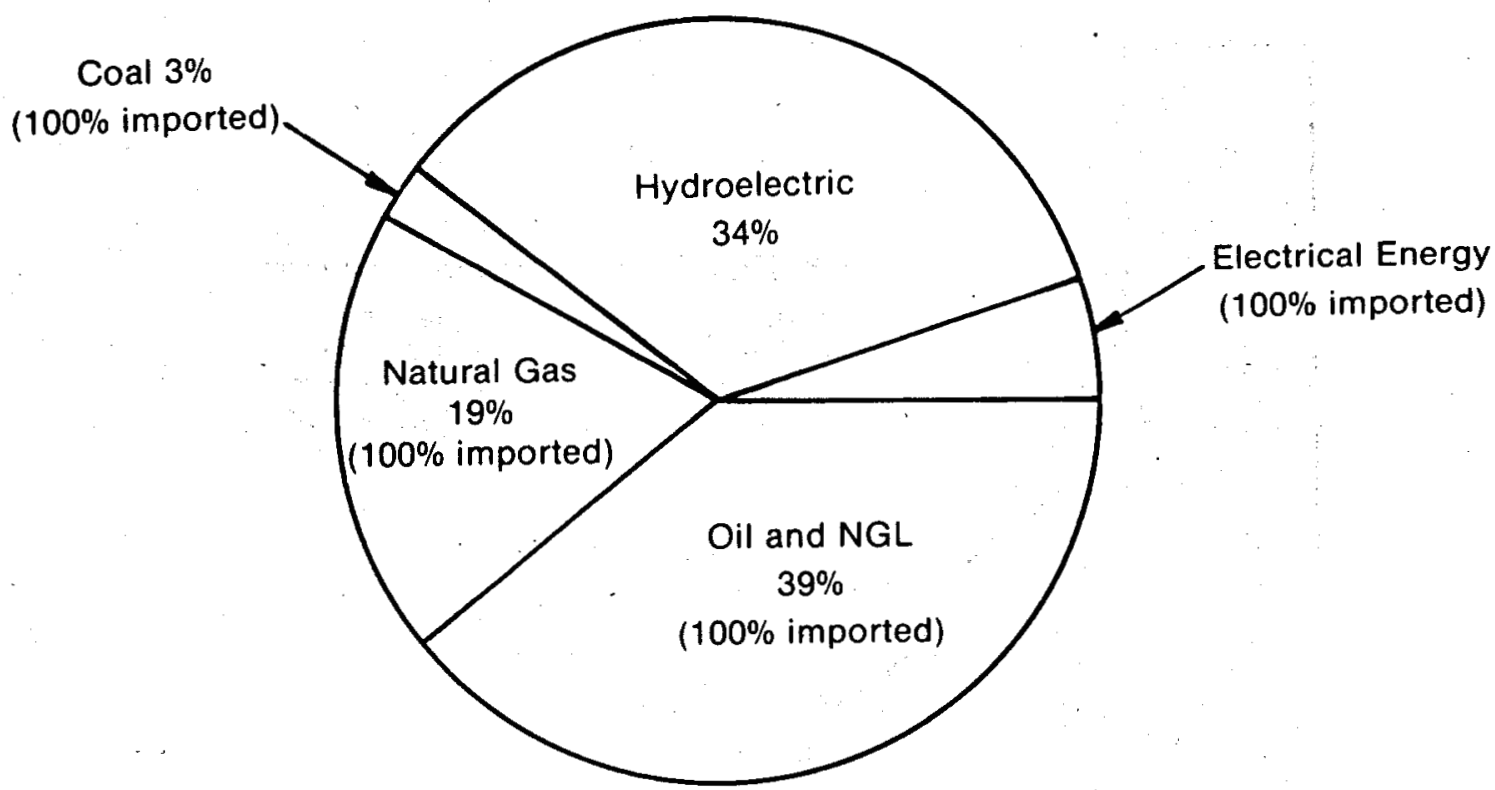

Energy Use
$\left(314.7 \times 10^{12} \mathrm{Btu}\right.$ 's)

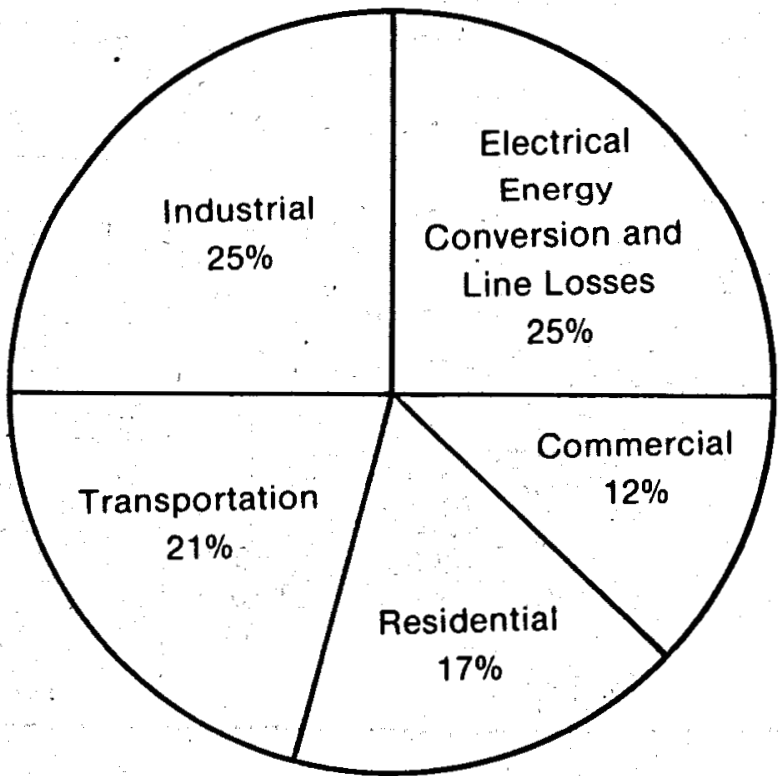

Fig. 12 Idaho energy supply and use. 


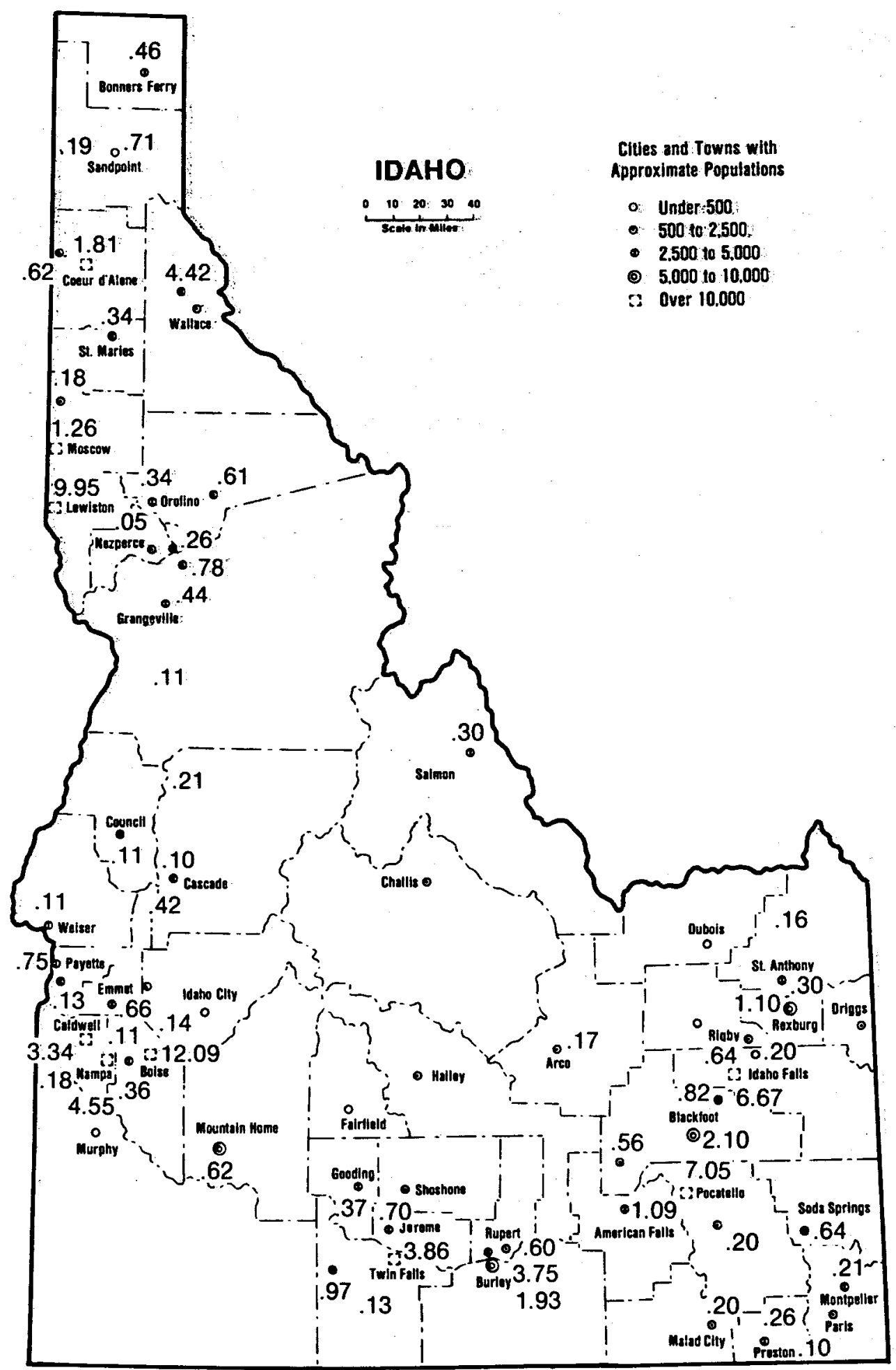

Fig. 13 Idaho energy usage map. 


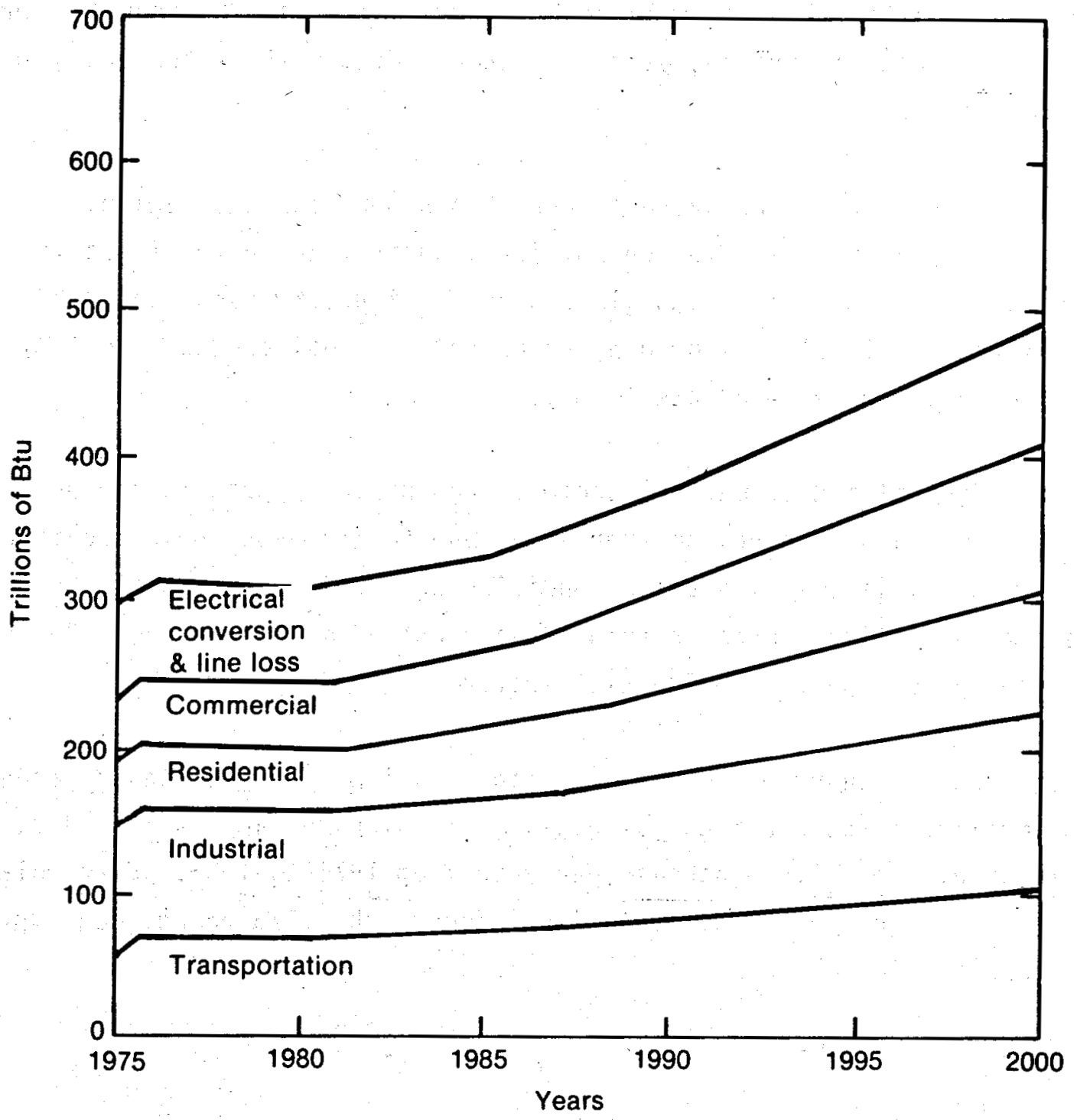

Fig. 14 Idaho total energy use projection. 


\section{STATE OF MONTANA ENERGY SUMMARY}

Montana's large deposits of coal make it a net exporter of energy (Figure 15). The state also exports a small amount of oil and an almost insignificant portion of its hydroelectricity. About $40 \%$ of Montana's natural gas is imported; this is the second largest energy source used by industry and the largest used in the residential sector. Figure 16 is the energy-use map for Montana.

Montana's industries are average energy consumers for the region. $0 i 1$ is the primary source of energy for industry, and natural gas is second. The stone, clay, and glass-products industry uses about $15 \%$ of the industrial total, followed by petroleum and coal products $(\sim 13 \%)$, and food and kindred products ( $8 \%$ ).

The residential and commercial sectors account for approximately one third of Montana's energy consumption. Due to its geographic location and its cold climate, its space conditioning requirements should be the same or a little greater than Idaho's which amounts to about $80 \%$ of the energy used by the residential sector.

Based upon the Energy Information Administration's projections, energy consumption in the northcentral region, of which Montana is included, will experience a $2.8 \%$ increase per year from 1975 to 1985 . Extrapolating this rate to the year 2000 will almost double the 1975 energy consumption as shown in Figure 17. 

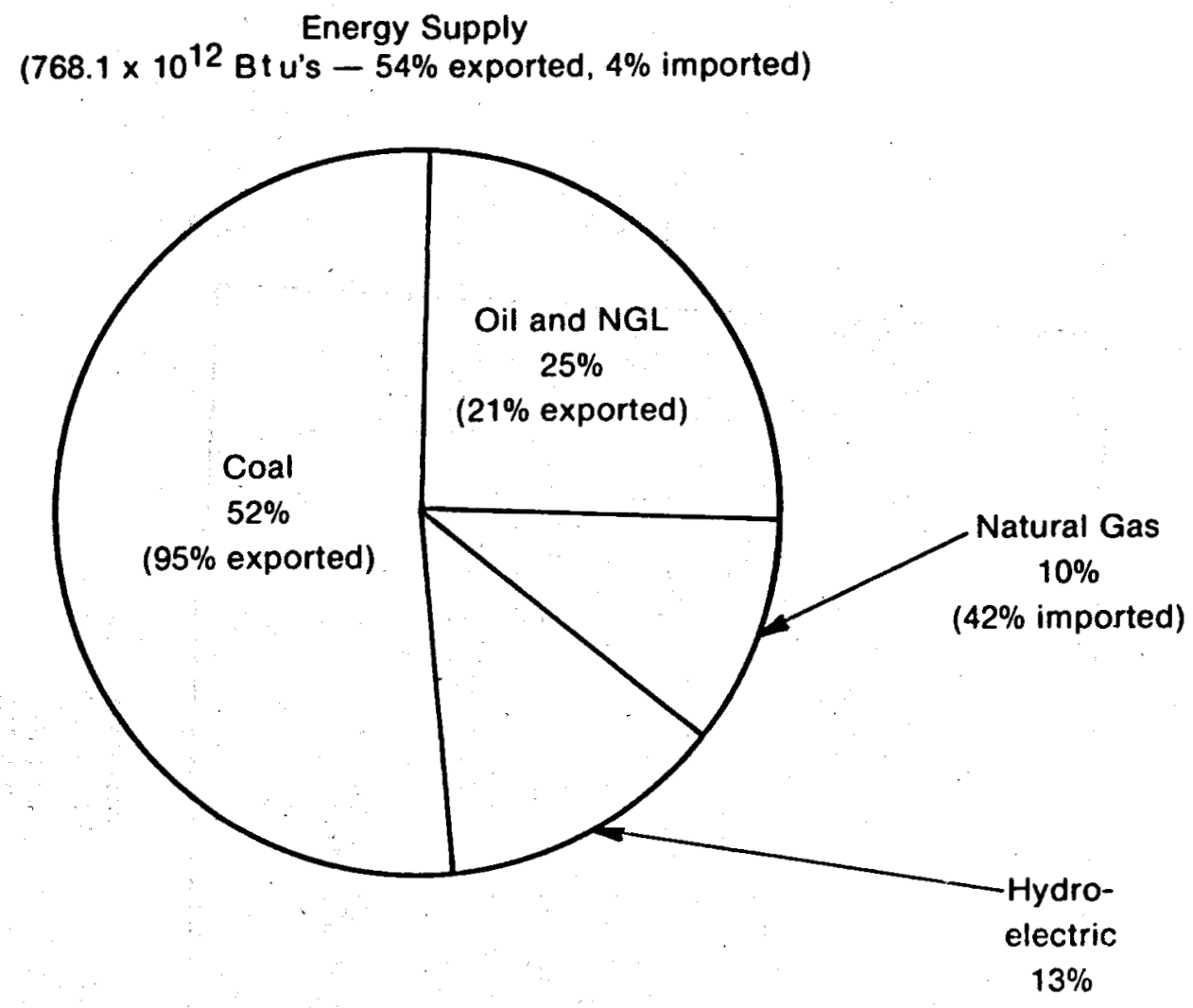

(3\% exported)
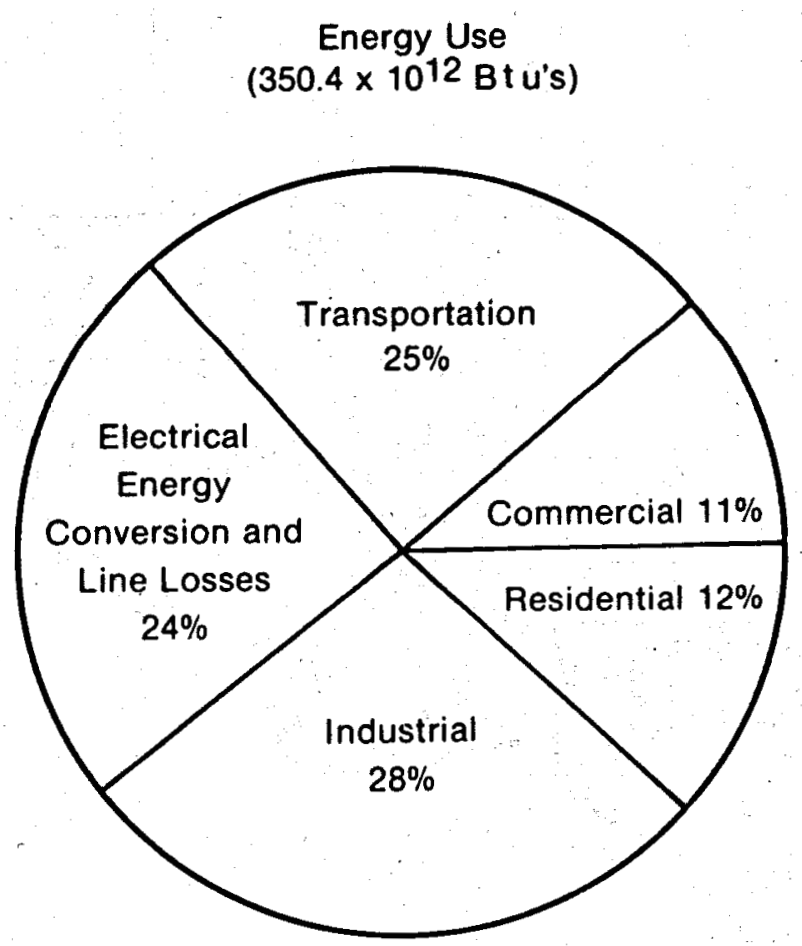

Fig. 15 Montana energy supply and use. 


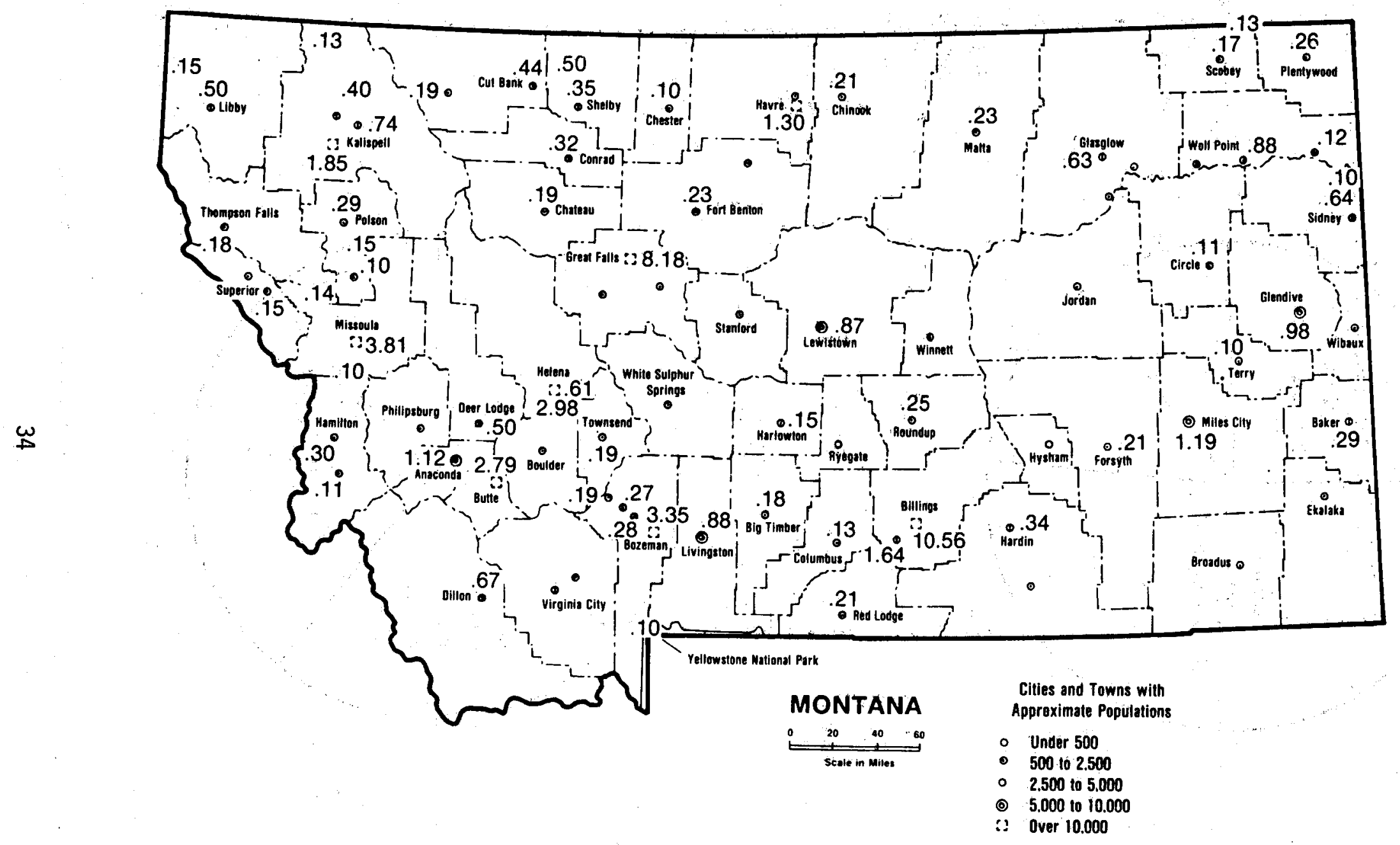

Fig. 16 Montana energy usàge màp. 


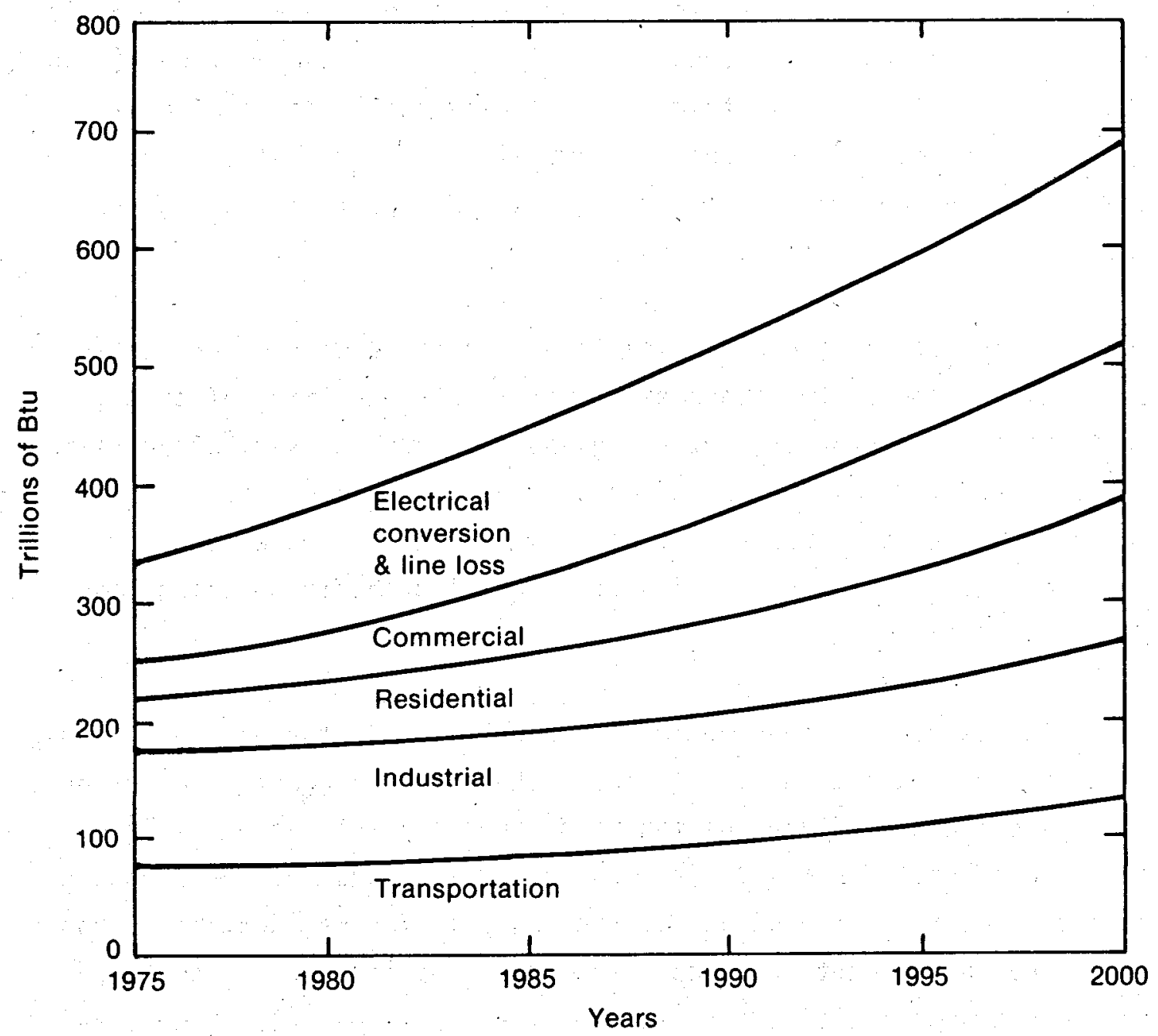

Fig. 17 Montana total energy use projection. 


\section{STATE OF NEVADA ENERGY SUMMARY}

Nevada imports almost al1 of its present energy supply (see Figure 18). Due mostly to the large distances between population centers, transportation is by far the largest energy-consuming sector in Nevada. Industry is the second largest energy consumer, using primarily natural gas ( $245 \%)$ and oil $(\sim 35 \%)$, with electricity and a very small amount of coal making up the remainder. The residential and commercial sectors use about as much electricity as natural gas. Figure 19 shows how much energy Nevada's communities consume.

Nevada's industrial sector is very small compared with other states in the region whose sector consumes approximately one third of that in ttath or Arizona. The stone, clay, and glass-products industry accounts for approximately $40 \%$ of the energy used by Nevada's industry. Natural gas has been the energy source most used by all of the above sectors except transportation, but Nevada's industries will probably be using less natural gas and more coal.

Nevada's residential consumption of energy exceeds the national average by a factor of about three. Although the northern counties experience more severe winters than the southern counties, the residential consumption of southern Nevada is about 2.75 times that of the northern part of the state. About $95 \%$ of the gas sold for residential purposes in the northern counties is used for space heating; in the southern counties a substantial amount is used for gas-fired absorption airconditioning. Figure 20 projects Nevada's energy demands through the year 2000 . 


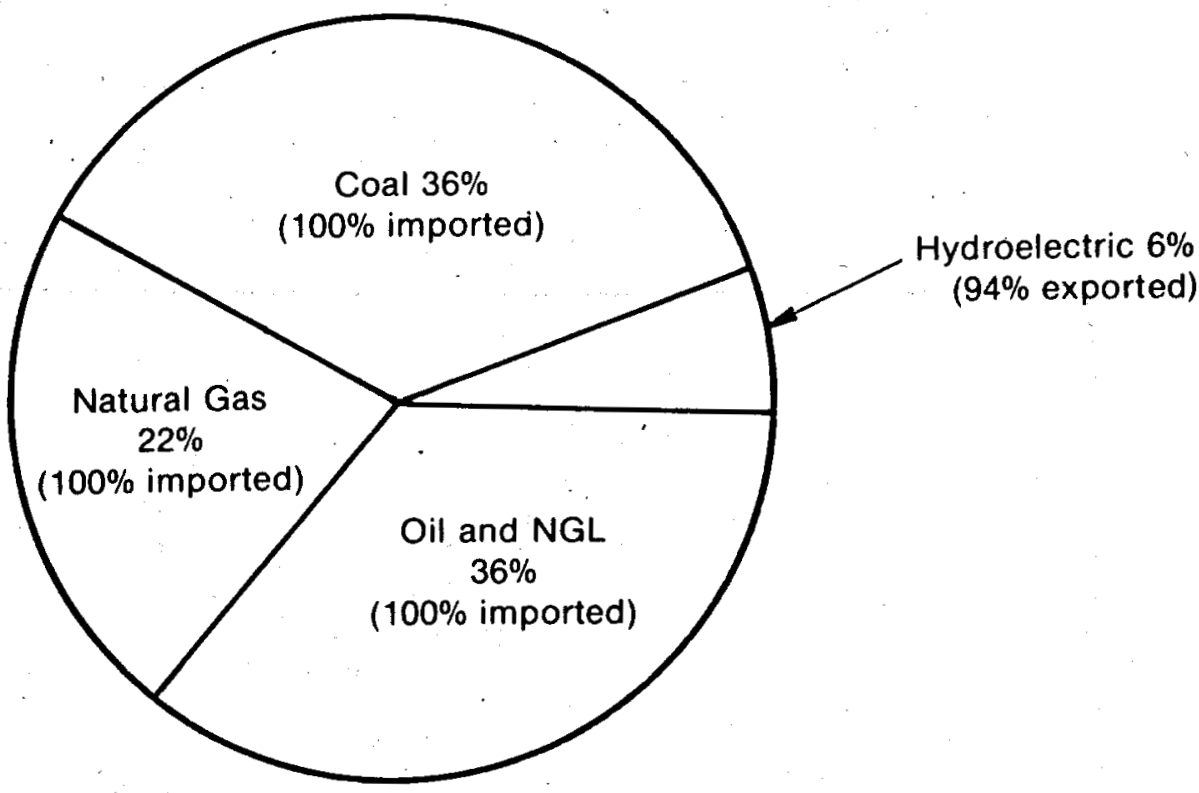

Energy Use

(268.6 x $10^{12}$ Bt u's)

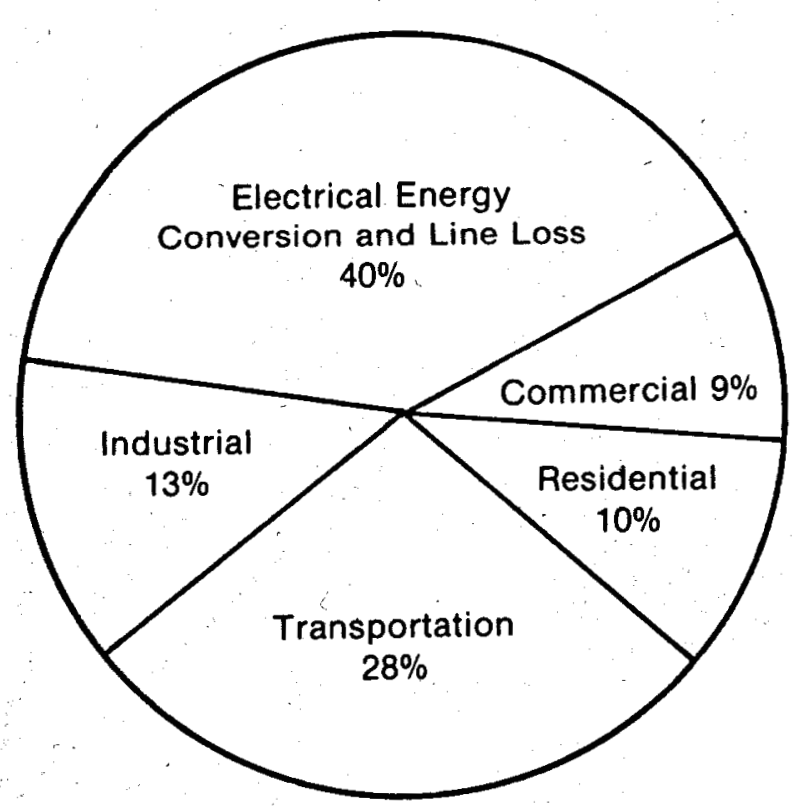

Fig. 18 Nevada energy supply and use. 


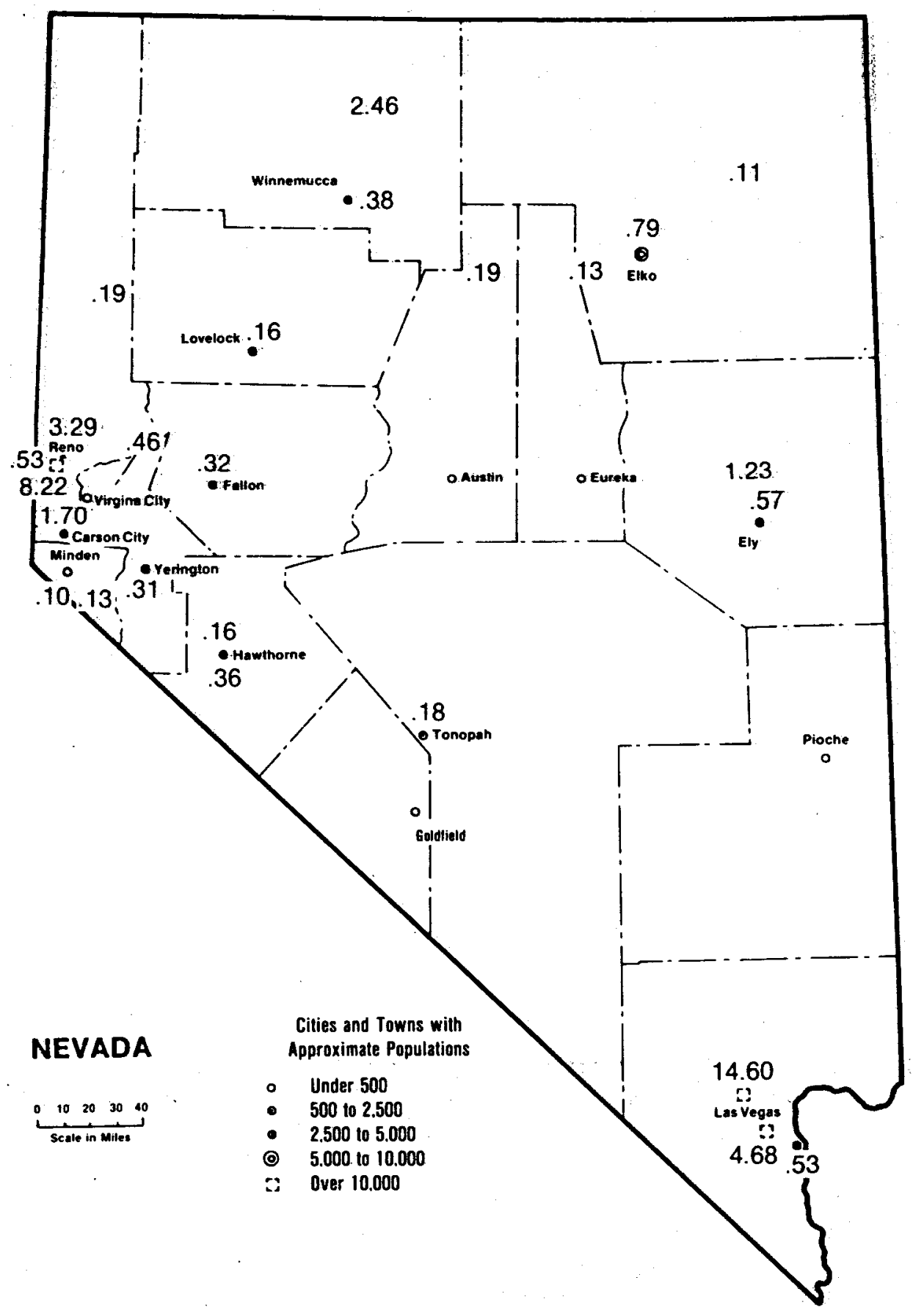

Fig. 19 Nevada energy usage map. 


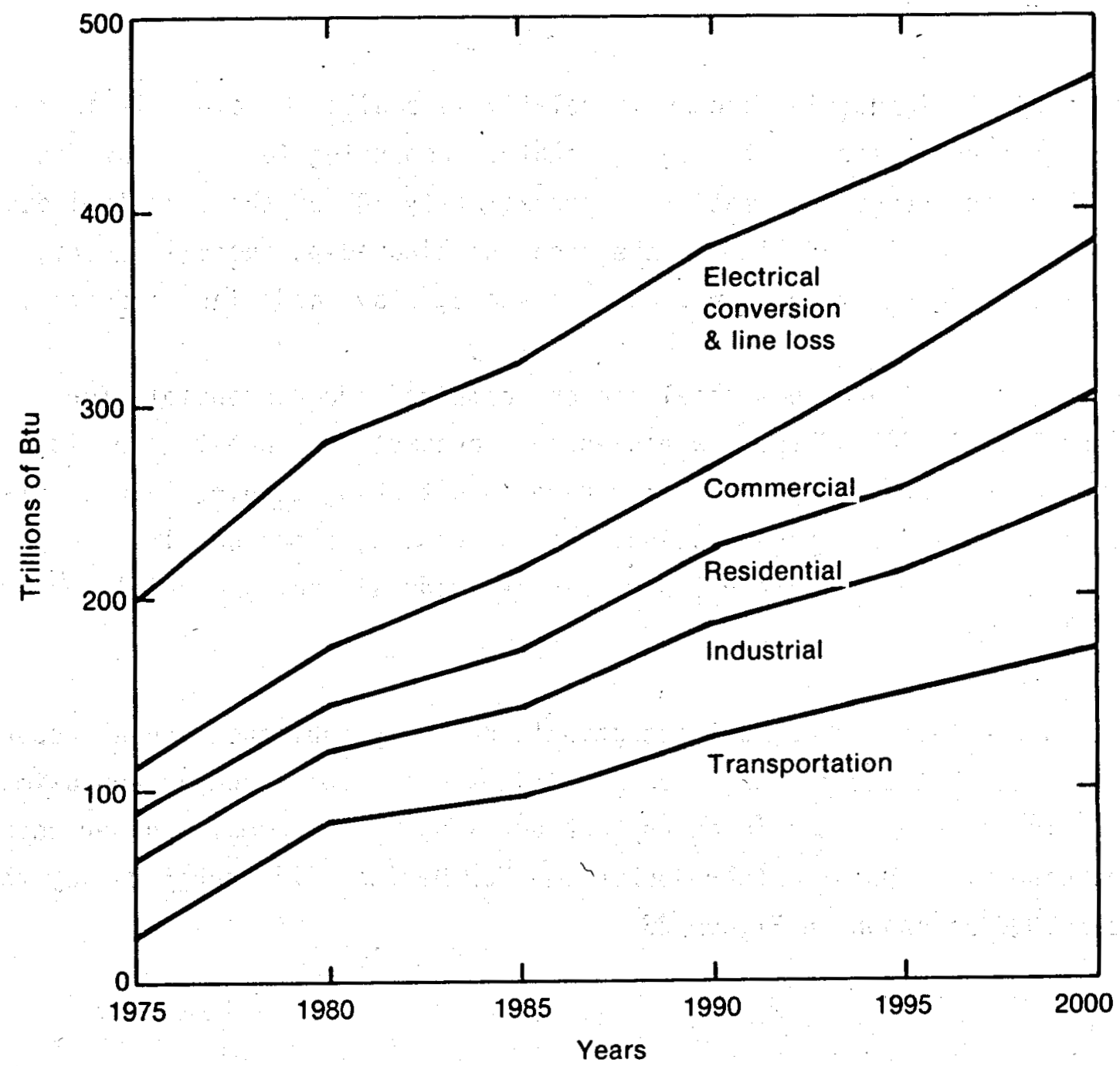

Fig. 20 Nevada total energy use projection. 


\section{STATE OF NEW MEXICO ENERGY SUMMARY}

The State of New Mexico exports much more energy than it uses (see Figure 21). Large quantities of uranium, oit, natural gas, and some coal are exported annually. Natural gas is currently the primary fuel used by the industrial, residential, and commercial sectors of the state. Figure 22 shows how much energy is used by communities throughout the state.

New Mexico's industrial sector is relatively small. However, it is the largest energy-using sector in the state, accounting for $\sim 35 \%$ of the total state energy consumption. Approximately $30 \%$ of the state's industrial energy consumption applies to the food and kindred-products industry, the wood and lumber industry, and the stone, clay, and glass industry.

The residential and commercial sectors combined are responsible for approximately $25 \%$ of the state's energy consumption. Due to the wide range of climates in New Mexico, space conditioning requires air conditioning as well as space heating. As in Arizona, space conditioning accounts for approximately $50 \%$ of the residential and commercial energy requirements.

The Energy Information Administration's recently published annual report estimates that the southwest United States will experience an approximate $2.7 \%$ increase per year in energy consumption. This normalized percentage increase will approximately double the New Mexico 1975 energy use by the year 2000 as shown in Figure 23. 

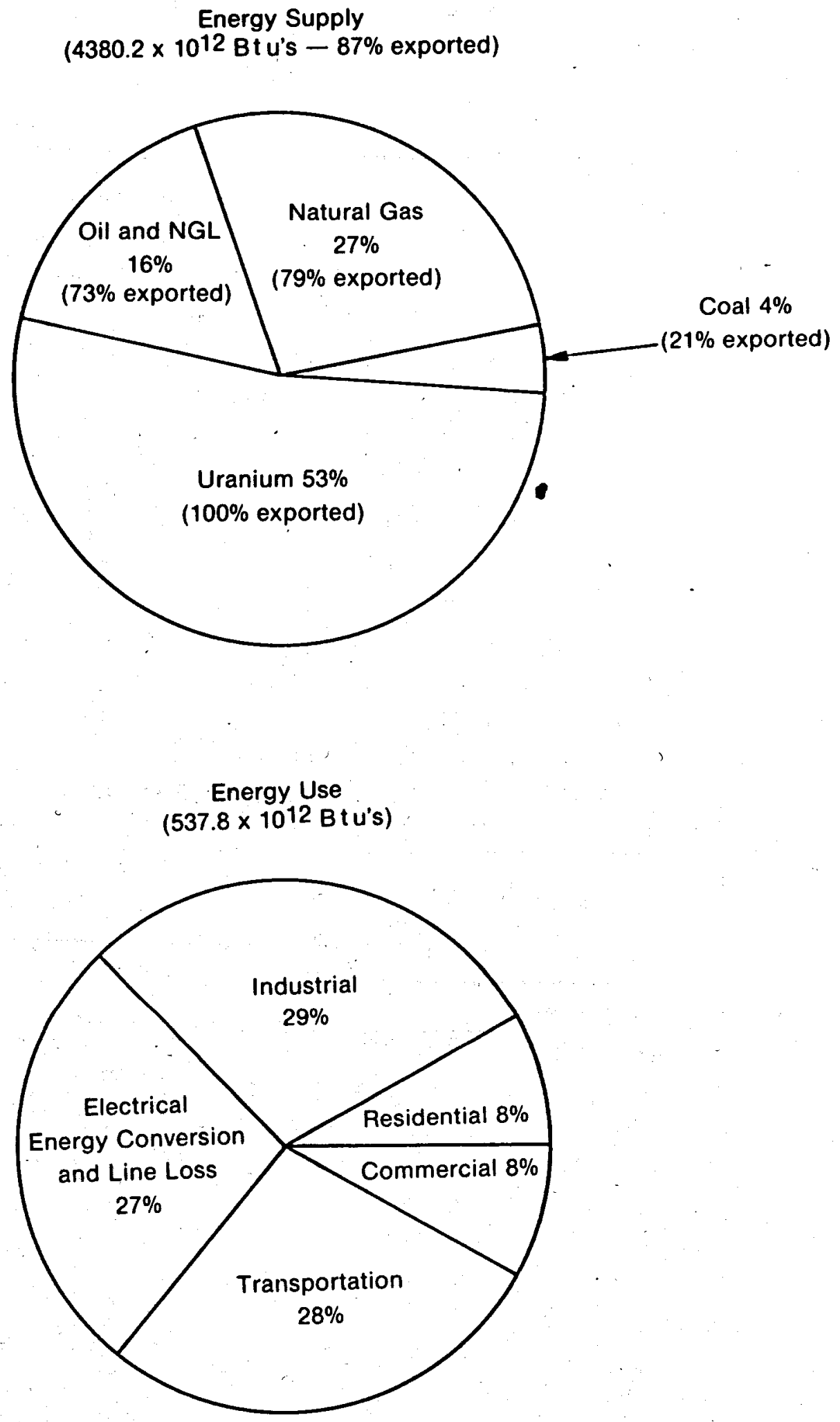

Fig. 21 New Mexico energy supply and use. 


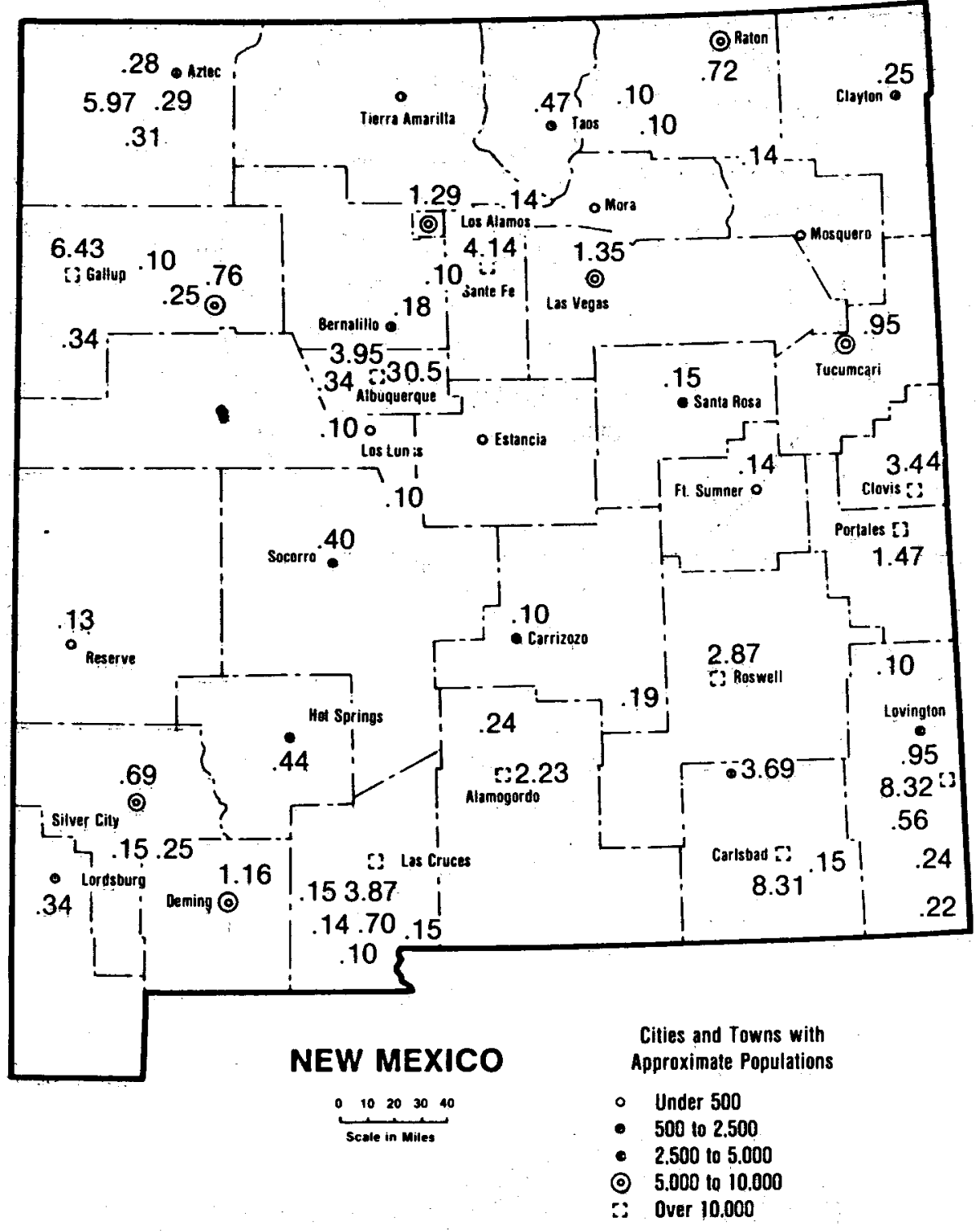

Fig. 22 New Mexico energy ușage map. 


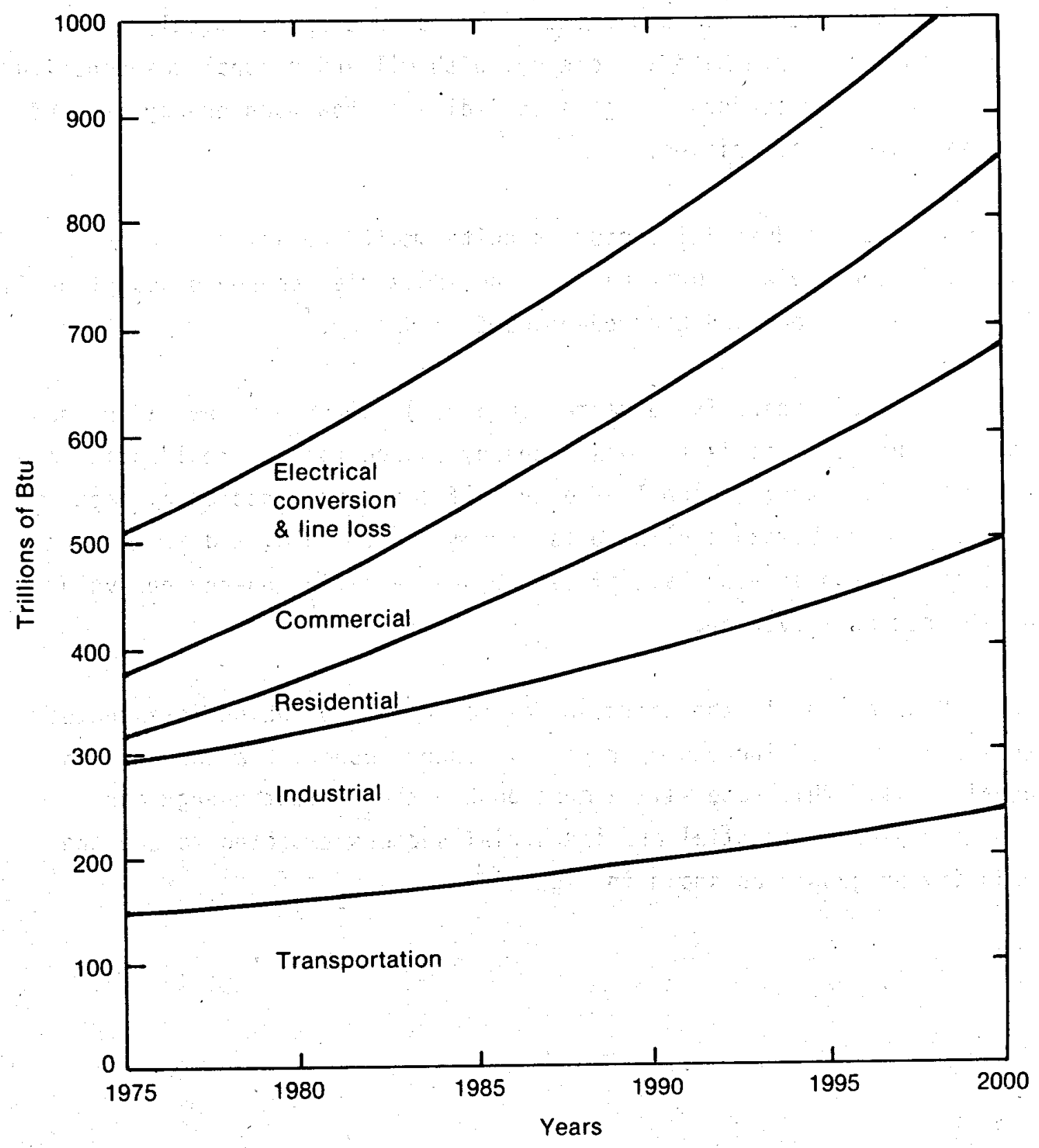

Fig. 23 New Mexico total energy use projection. 
North Dakota is a net energy exporter, exporting coal, oil, and electricity and importing approximately $40 \%$ of its natural gas (see figure 24 ). Transportation is the largest energy-consuming sector in North Dakota, accounting for $32 \%$ of the total energy consumption. The other sectors-industrial, residential, and commercial--consume approximately equal proportions of North Dakota's energy, with oil and natural gas constituting the major energy sources. Figure 25 indicates how much energy is used by the state's communities.

North Dakota's industrial sector is quite small, relative to other states in the region. Over half of the industrial energy consumption is by the state's food and kindred-products industry.

North Dakota is sparsely populated $(635,000)$, with very few major population centers. $0 i 1$ is the major energy source for the residential and commercial sectors; it supplies over half the energy needed by each sector. North Dakota's climate is predominantiy cold, and it requires from two to two-and-one-half times the space-heating energy per volume as the national average.

North Dakota lies in the northcentral census region which is expected to exhibit a $2.8 \%$ increase per year in energy use with a business as usual basis. This rate will almost double the current energy consumption with residential and industrial sectors expected to see the majority of growth as shown in Figure 26. 
Energy Supply

(287.7 $\times 10^{12}$ Bt u's $-5 \%$ imported, $18 \%$ exported)

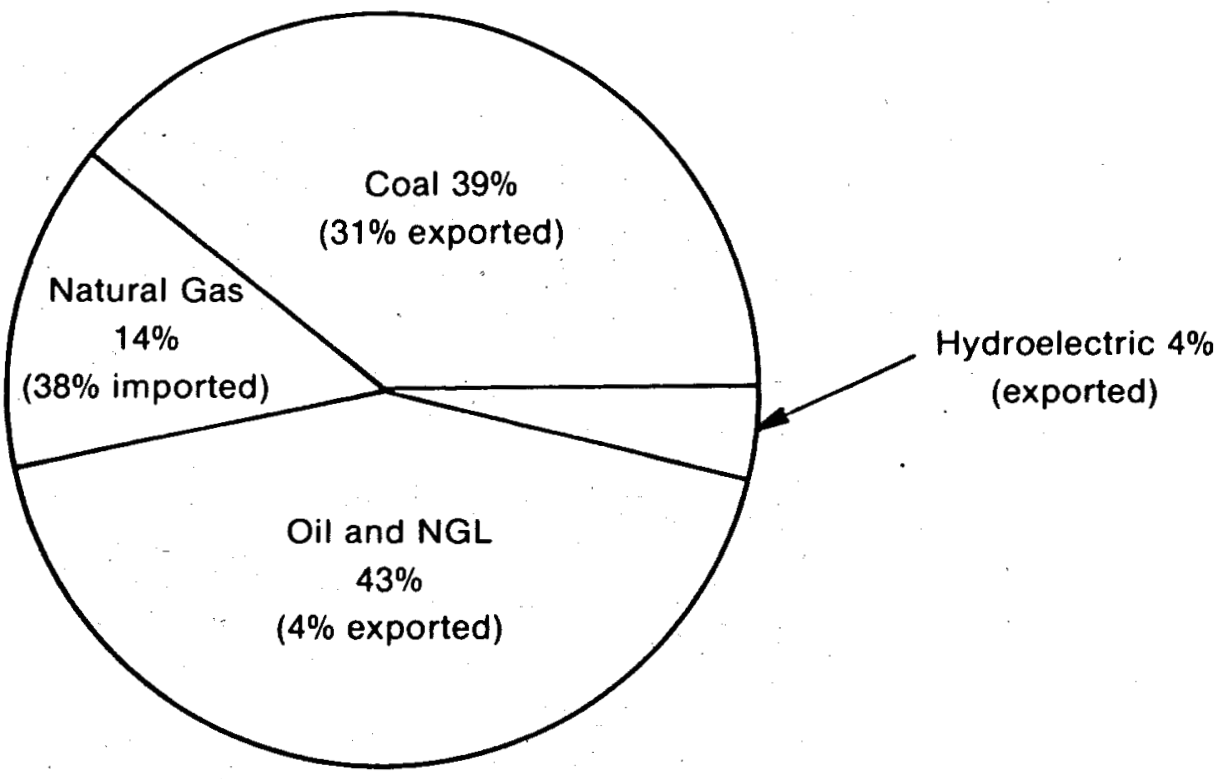

1

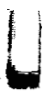

Energy Use

(226.0 $\times 10^{12} \mathrm{Btu}$ 's)

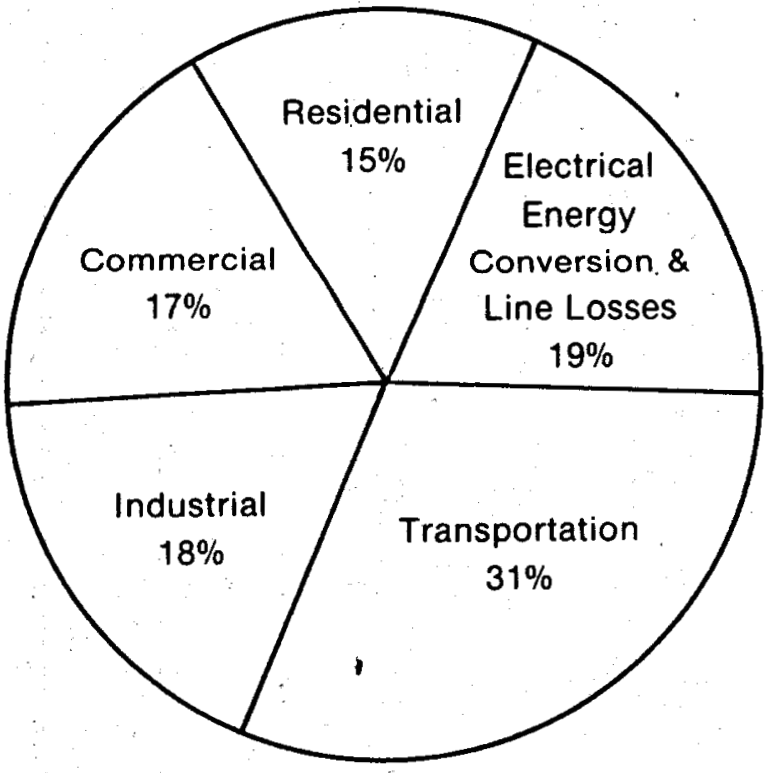

Fig. 24 North Dakota energy supply and use. 

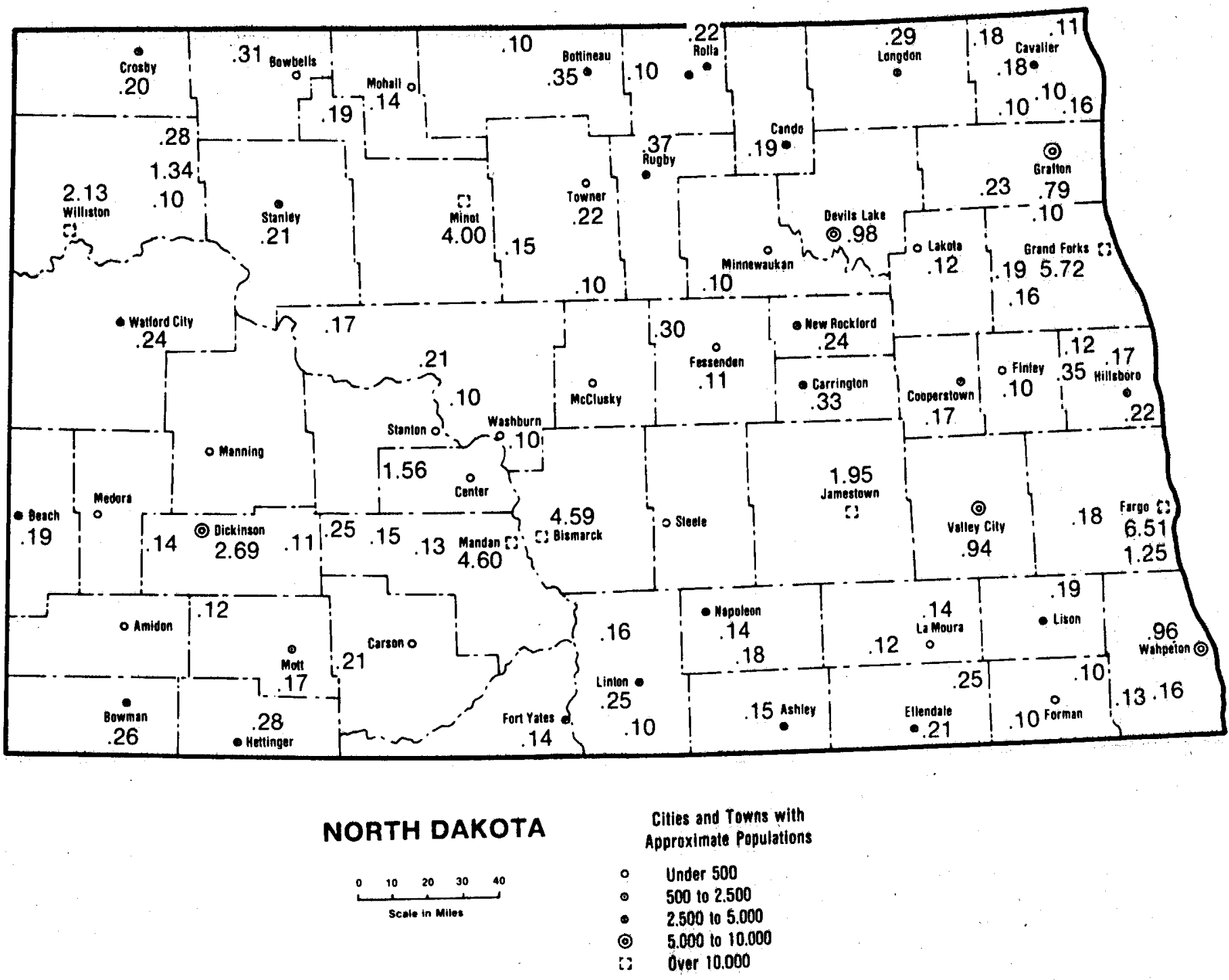

Fig. 25 North Dakota energy usage map. 


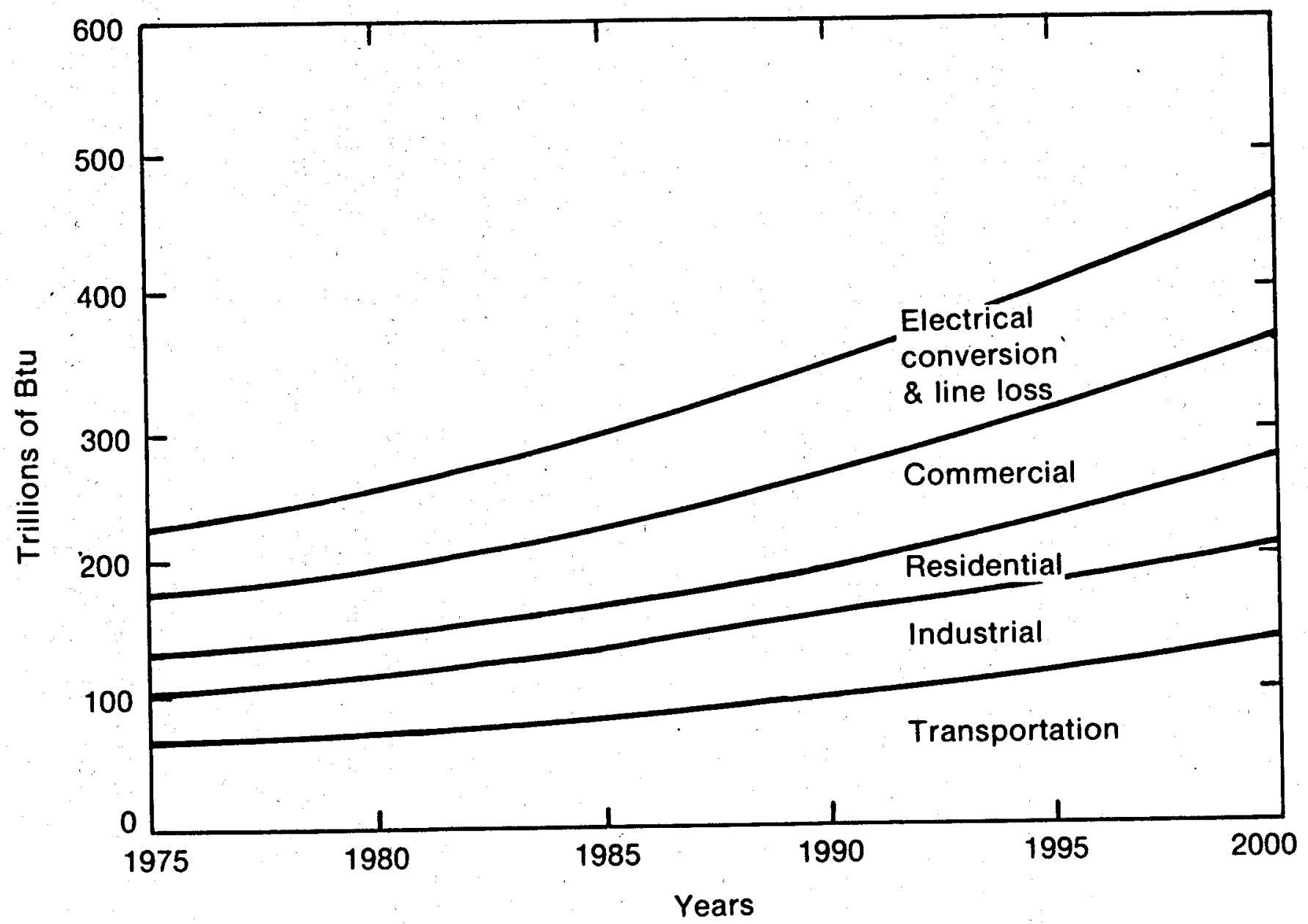

Fig. 26 North Dakota total energy use projection. 


\section{STATE OF SOUTH DAKOTA ENERGY SUMMARY}

Over the past twenty years, the state of South Dakota has been characterized by the total lack of population growth, so past and projected growth in energy' consumption are essentially due to a per-capita increase in energy use. Because of the sparse population and great distances between the few urban centers, transportation is by far the largest user of energy--considerably larger than the national average. Except for a few oil wells, and some coal fields which have been worked only intermittently over the last decade, the only sizable energy producer in South Dakota is hydroelectric (see Figure 27). Much of this energy is exported to surrounding states. Figure 28 gives approximate energy-use figures for population centers in the state. The percentage of energy used for industrial purposes is the smallest of the states in the region; however, over three-fourths of this energy is used by industries requiring mostly: low- to intermediate-temperature energy, as in the food and lumber industries.

The next largest use of energy is for residential and commercial purposes. Except for North Dakota, South Dakota is the coldest state in the region; indeed, it is one of the coldest in the entire United States. Based on a district heating factor, its heating requirements are double the national average, and are exceeded by those of only two or three other states in the upper midwest. In the western part of the state, propane is the primary source of residential heating. Available information does not make clear, however, whether this use of propane applies to urban as well as to rural areas.

Figure 29 approximates the growth in demand for South Dakota. It is expected that South Dakota's energy demand will nearly double by the year 2000 (caused mostly by a per-capita increase in energy use). 


\section{Energy Supply}

(193.7 $\times 10^{12}$ Bt u's - 84\% imported, 9\% exported)
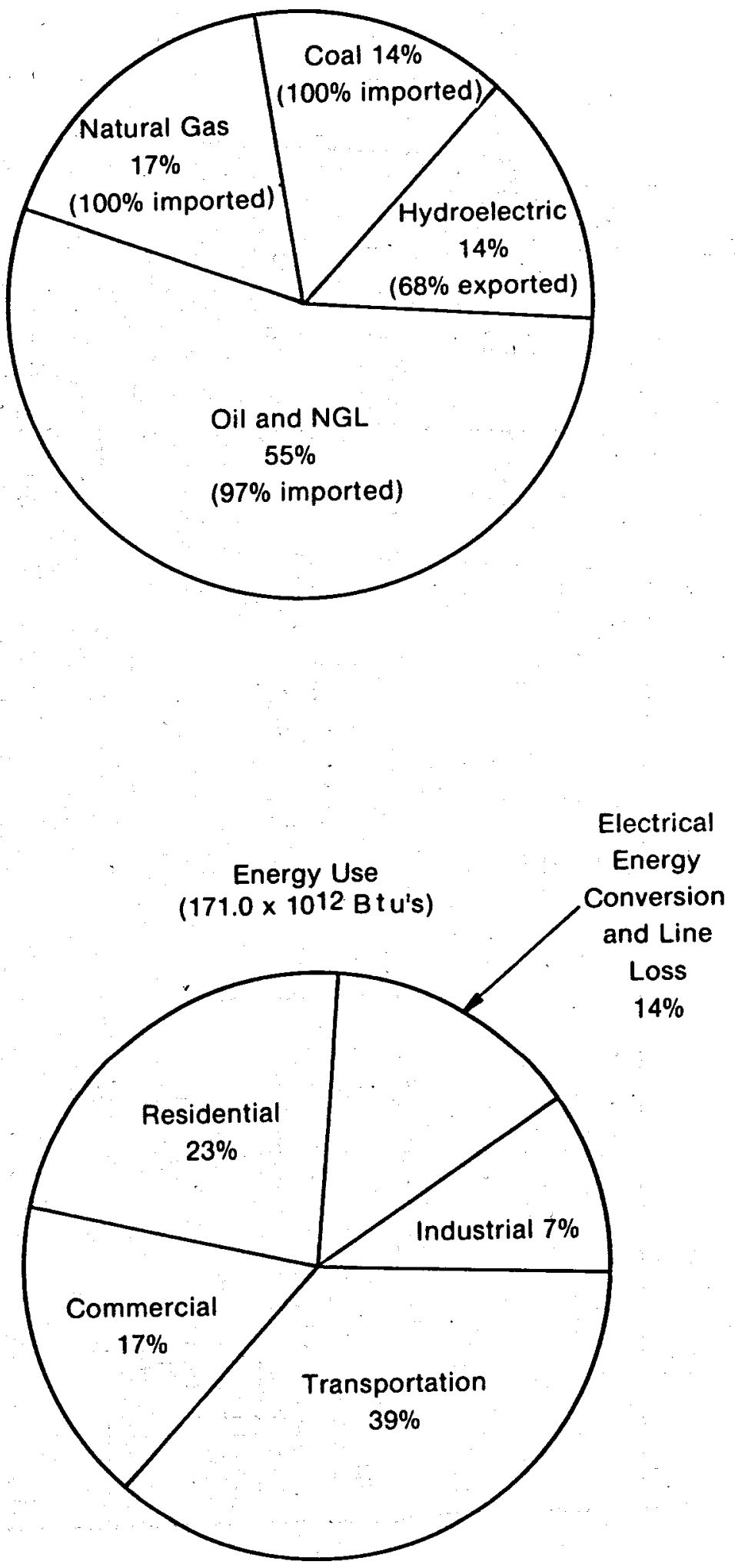

Fig. 27 South Dakota energy supply and use. 


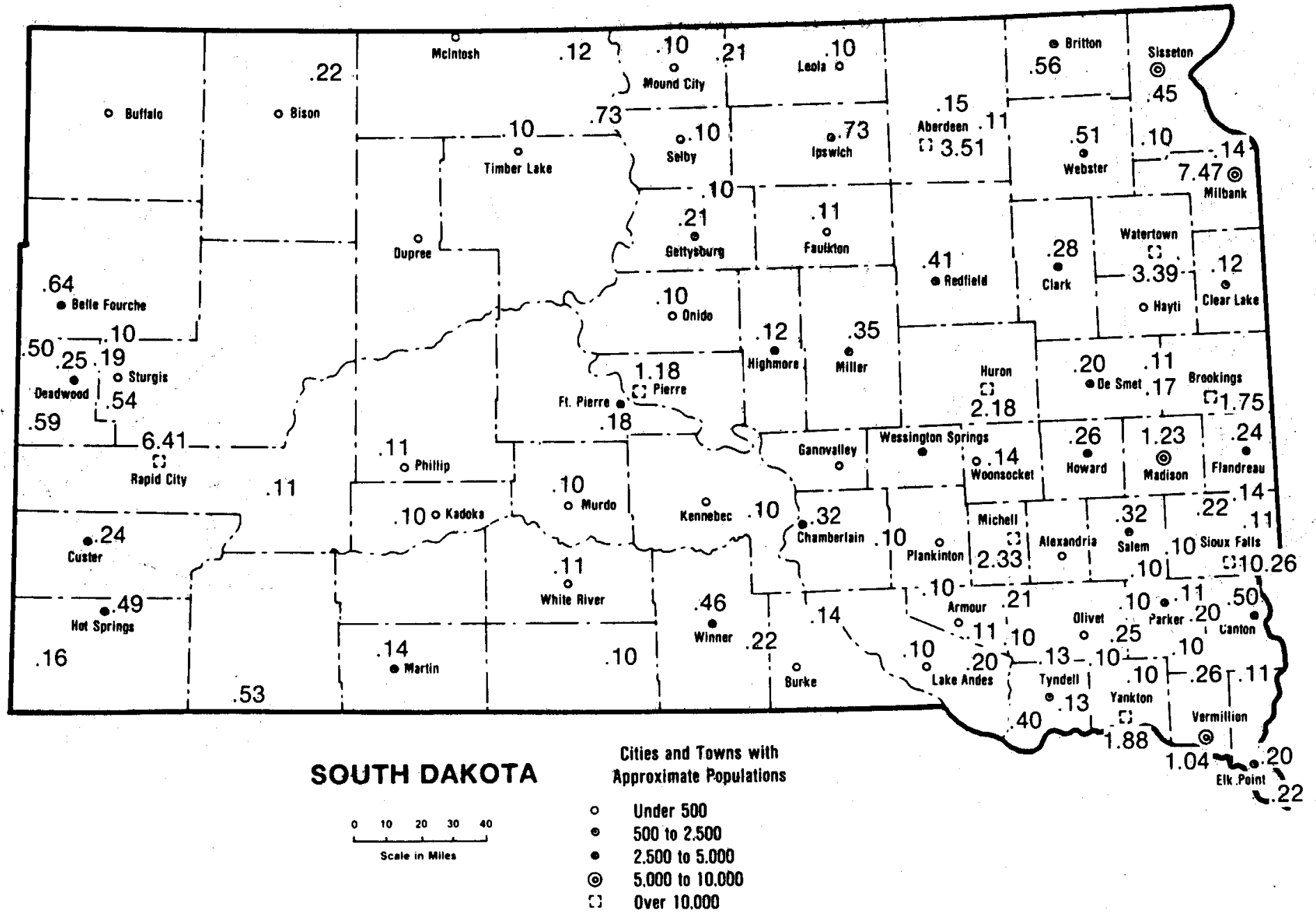

Fig. 28 South Dakota energy usage map. 


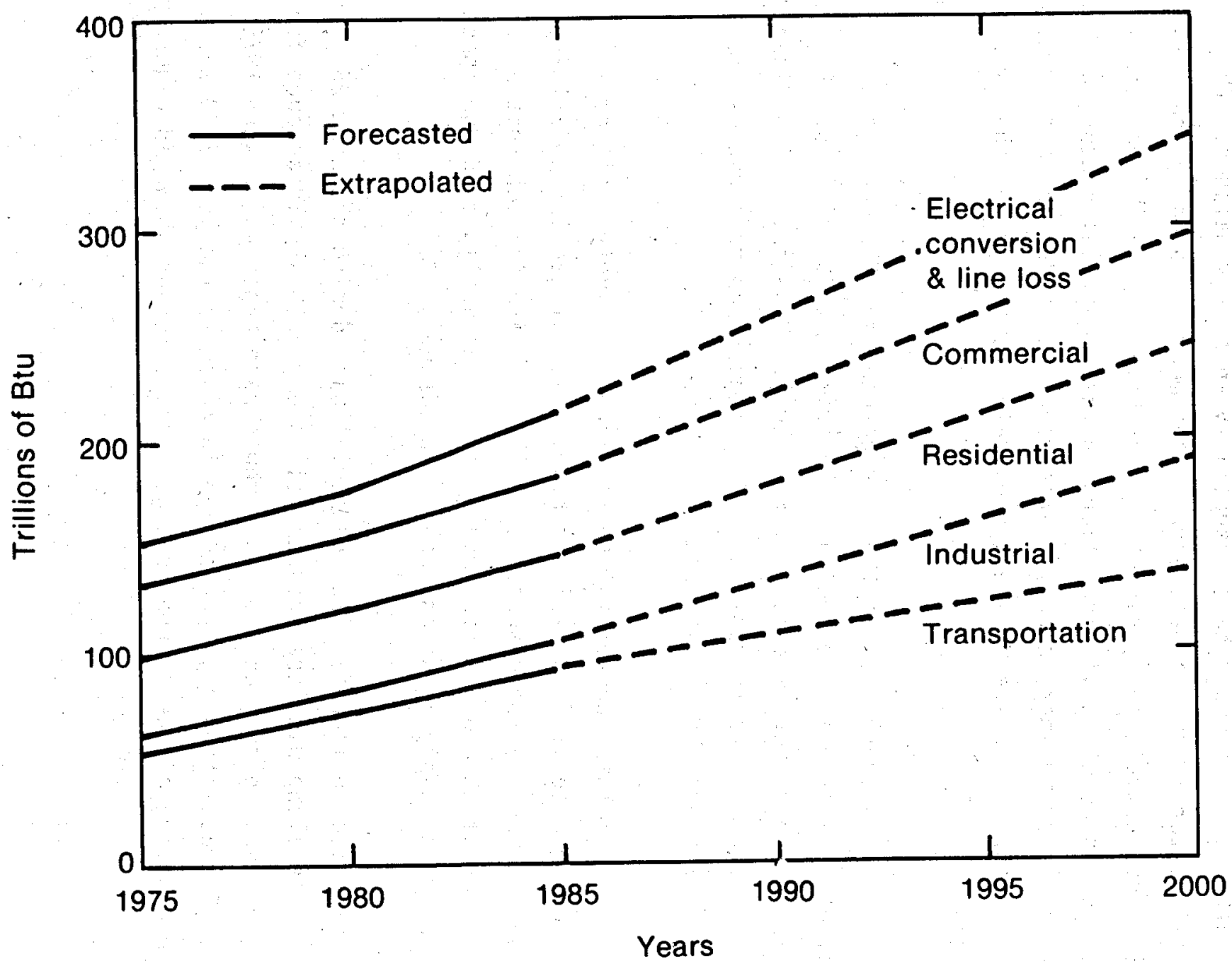

Fig. 29 South Dakota total energy use projection. 


\section{STATE OF UTAH ENERGY SUMMARY}

Utah is a net energy exporter, exporting uranium, oil, and coal, while importing natural gas and a small amount of electricity (see Figure 30 ). The export of uranium is the primary reason Utah is a net exporter of energy; otherwise, it would have essentialty an energy bailance. The industrial sector is the largest energy consumer, followed by the transportation, commercial, and residential sectors. 0il, coal, and natural gas are used in about equal proportions in the industrial sector, while natural gas is the primary energy source for the residential and commercial sectors. Figure 31 indicates the approximate energy use for the communities of the state.

Utah's industries consume about the same percentage of energy as do those of other states in the region. The printary industrial use of energy is by the primary metals sector $(\sim 50 \%)$. However, a significant amount of the remainder $(\sim 25 \%)$ is used by industries that can use lowto intermediate-heat energy sources.

Utah's residential and commercial sectors are relatively small consumers, compared to its industrial sector. Naturat gas is the primary energy source used by these sectors. Utah's climate is such that a large portion of the energy consumed in these sectors is used for space conditioning--probably about as much as in Idaho.

Utah is expected to increase its industrial base during the next 25 years. This increase along with the residential base growth should account for the $2.8 \%$ per year energy consumption growth rate expected between 1975 to 1985. Extrapolating this percentage increase to the year 2000 shows aTmost a doubling of the current energy consumption as shown in Figure 32 . 


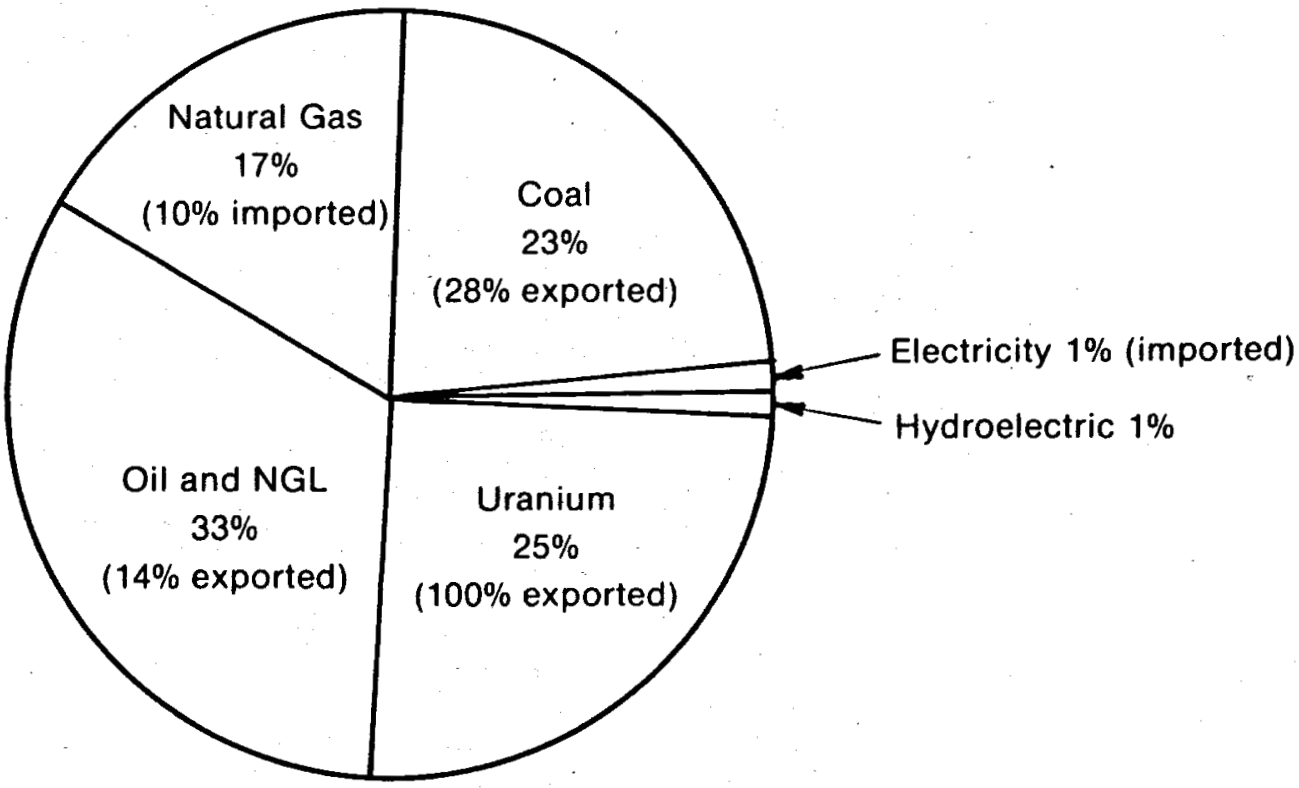

Energy Use

$\left(472.1 \times 10^{12} \mathrm{Btu}\right.$ 's $)$
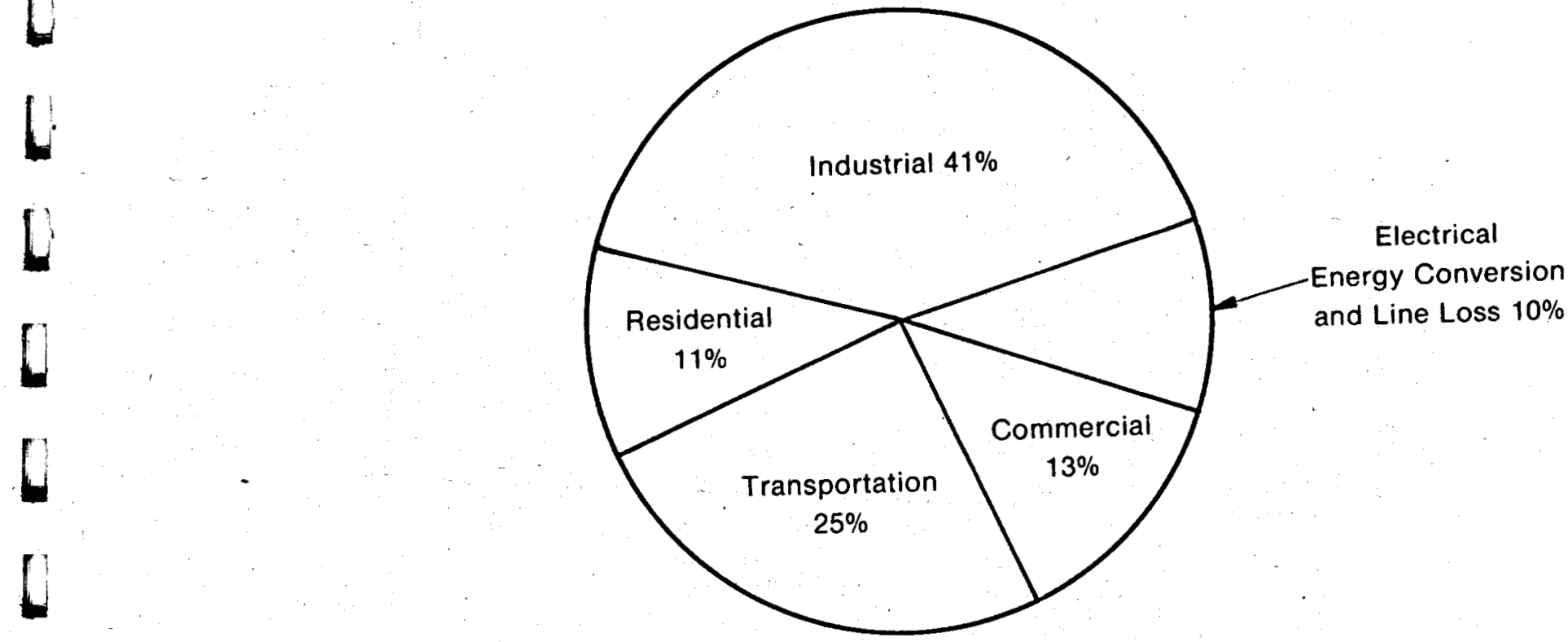

Fig. 30 Utah Energy Supply and Use. 


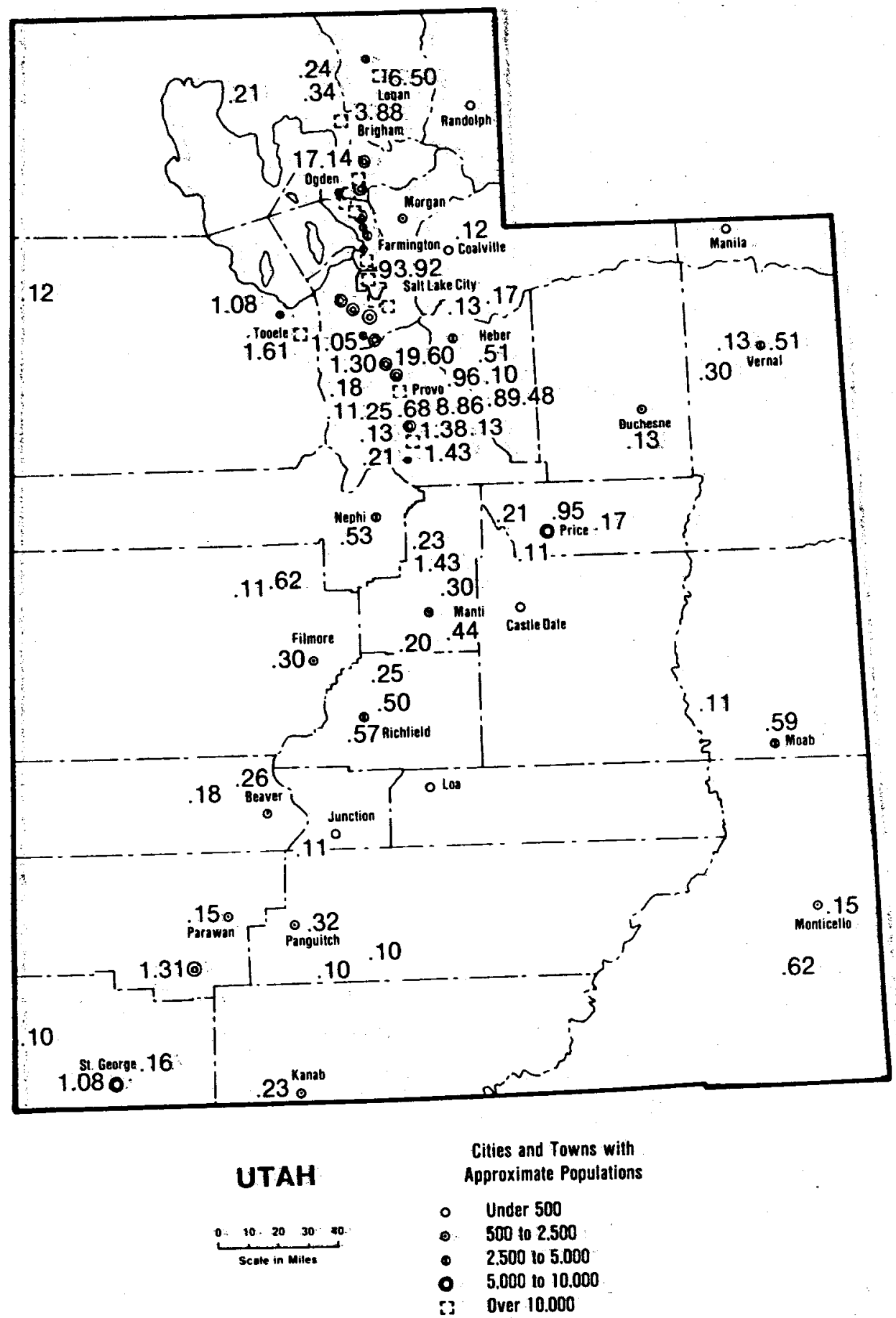

Fig. 31 Utah energy usage map. 


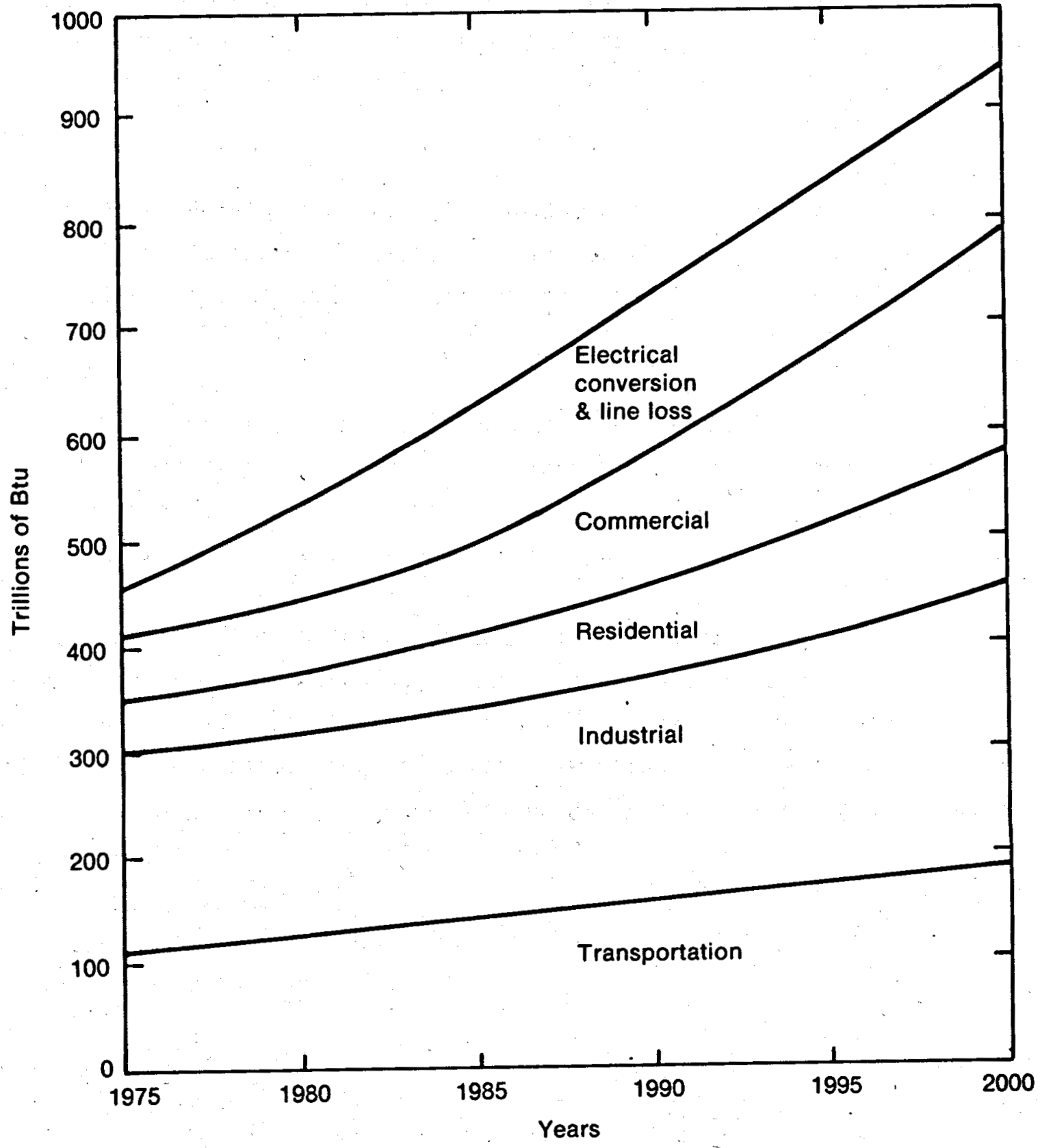

Fig. 32 Utah total energy use projection. 
Wyoming is the region's leading exporter of energy (see Figure 33). It exports larger quantities of all energy sources than it consumes. The industrial sector is the largest energy consumer, followed by transportation, then by the commercial and residential sectors. All sectors use mostly oil and natural gas. Figure 34 shows how much energy is used by the state's communities.

The petroleum and oil-products sector uses approximately $65 \%$ of the energy consumed by Wyoming industries. However, approximately $15 \%$ of the remaining use is by industries that can use low- to intermediateheat energy sources.

The residential and commercial sectors use primarily oil and natural gas. It can be assumed that the space conditioning requirements for Wyoming are similar to those of its neighboring states, which range from about 70 to $80 \%$ of the energy used by these sectors .

Wyoming, as part of its surrounding states in the northcentral census region should experience an average $2.8 \%$ increase per year in their energy consumption. This growth increase is expected from the industrial and residential sectors, which will cause an approximate doubling of the current energy consumption as shown in Figure 35. 
D

$\left(3,156.1 \times 10^{\text {Energy Supply }}\right.$ Bt u's $-88 \%$ exported $)$ Natural

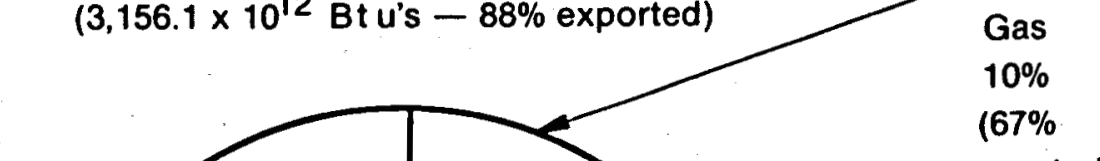

1

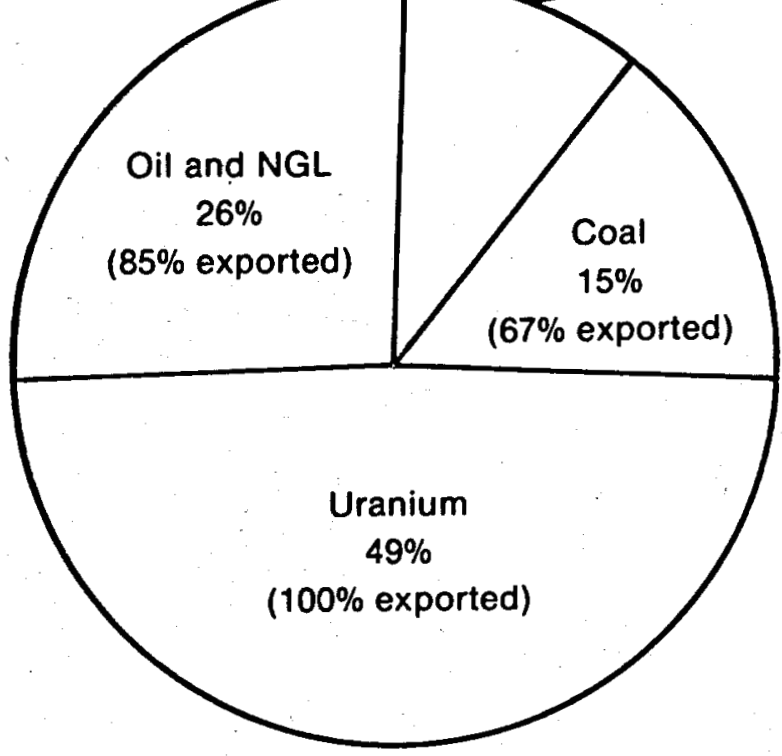
exported)

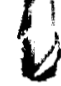

$\downarrow$

5

Energy Use

(325.8 $\times 10^{12} \mathrm{Btu}$ 's)
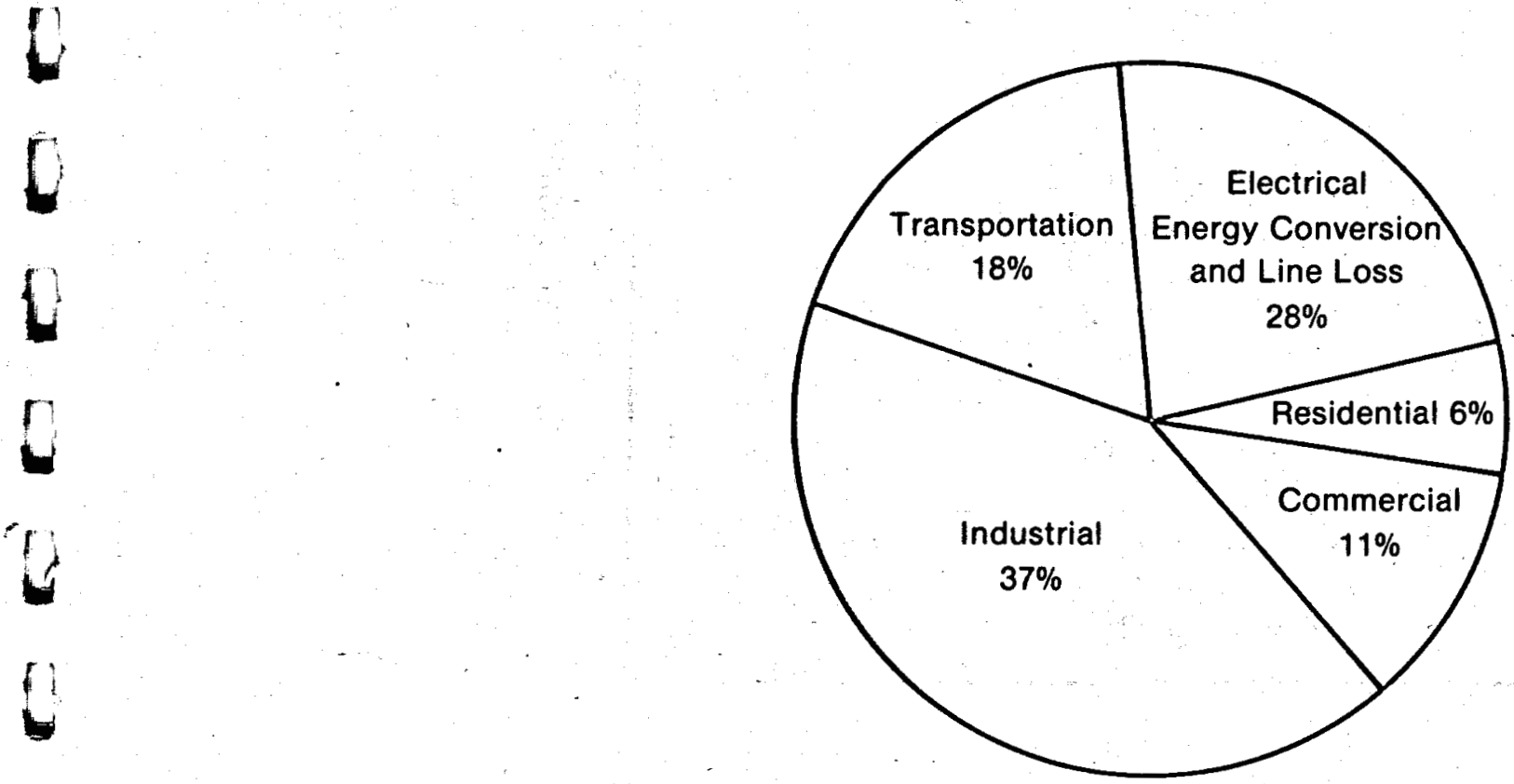

Fig. 33 Wyoming energy supply and use. 


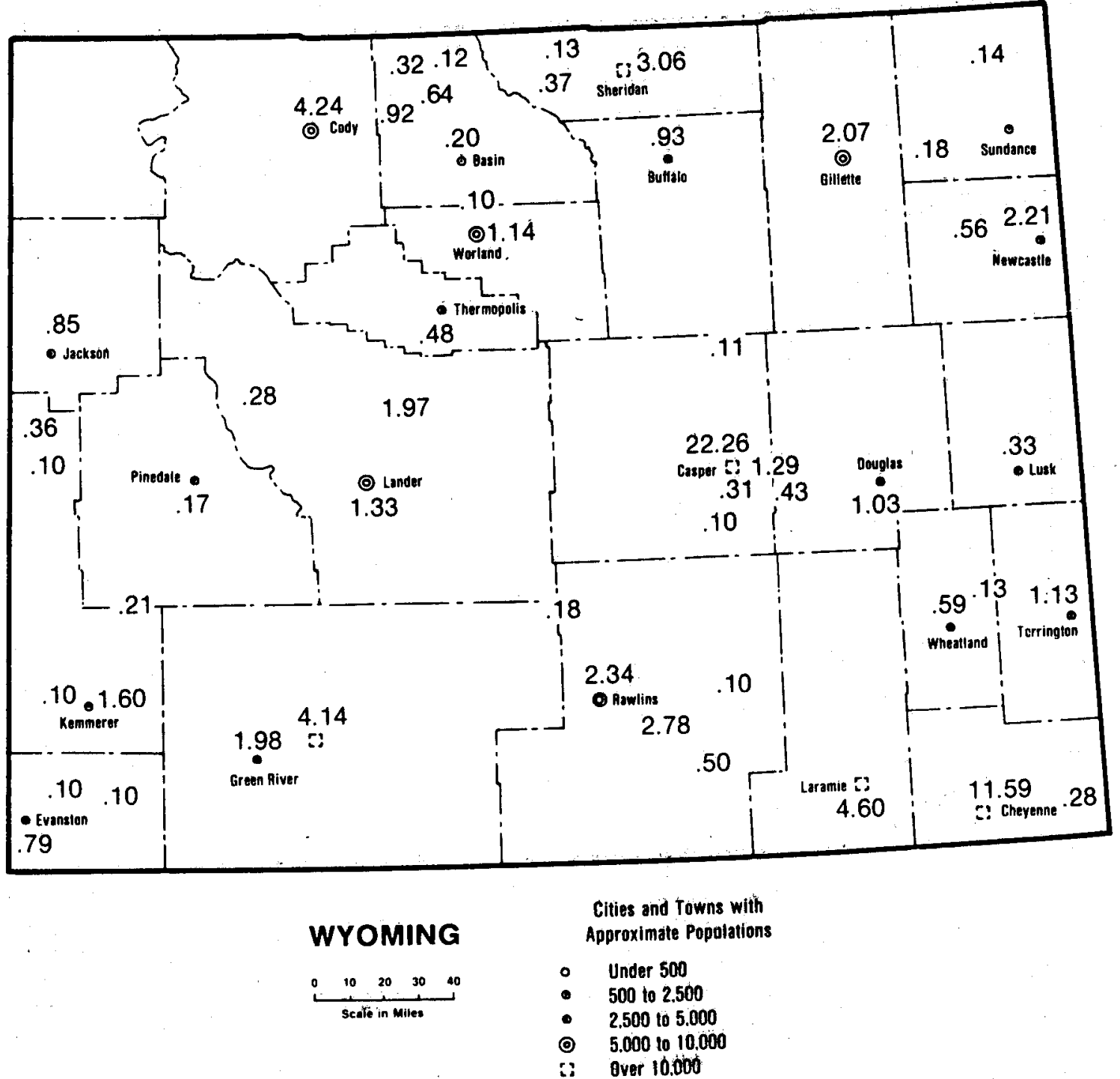

Fig. 34 Wyoming energy usage map.

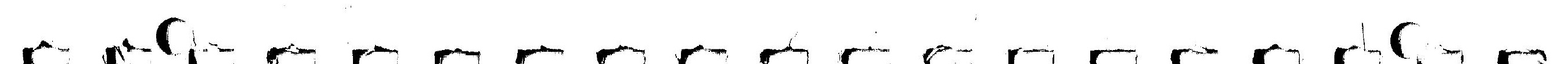




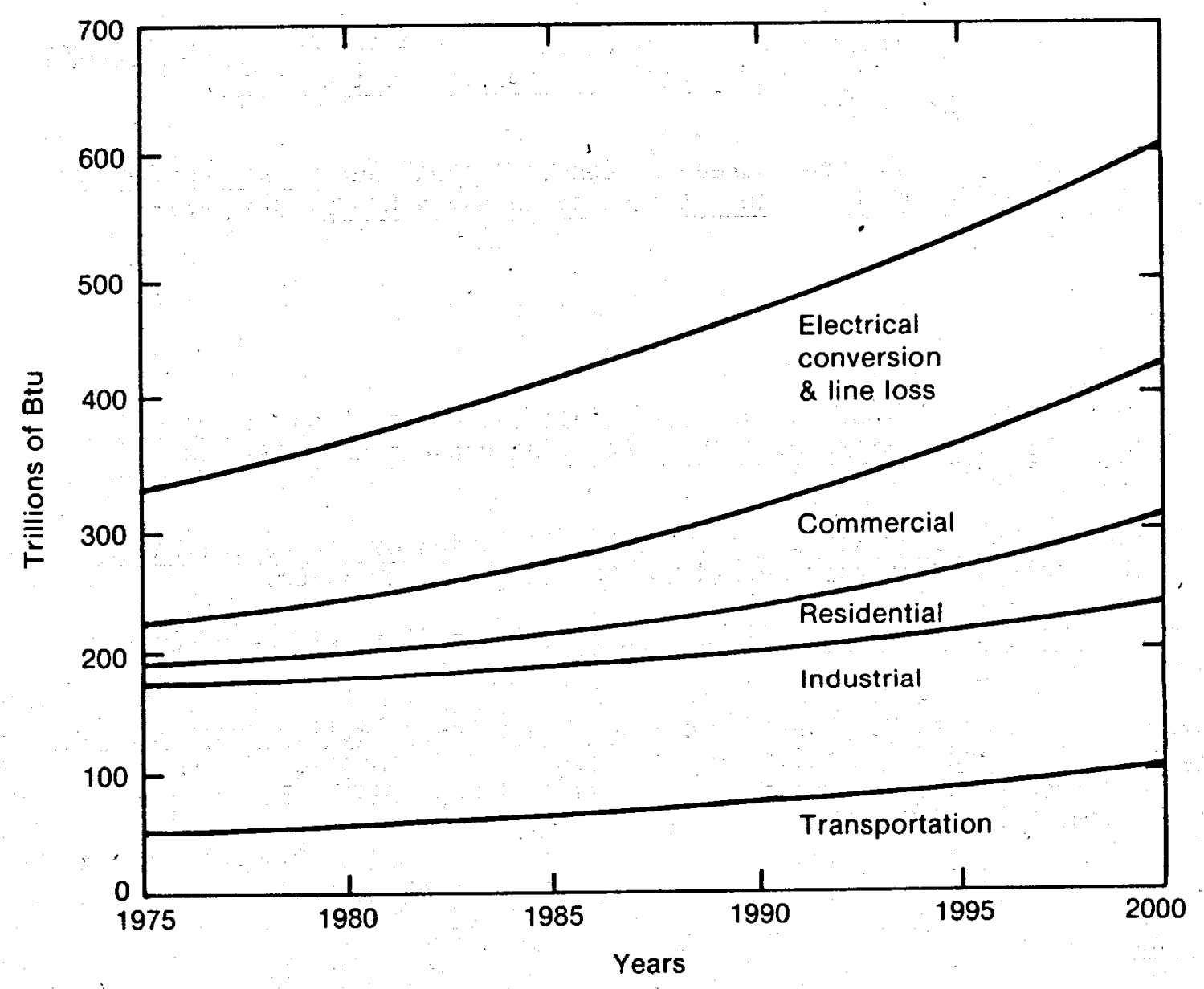

Fig. 35 Wyoming total energy use projection. 


\section{REFERENCES}

Regional

1- Charles D. Kolstad, The 1975 Energy Production System in the States of the Rocky Mounta in Region, LA-6624 (UC-95C) (December 1976).

2- Rocket Research Company, Industrial Waste Heat for Adjacent Communities and Industrial Applications, Task 1, RRC-78-H-181 (December 21, 1977) (Available from Pacific Northwest Regional Commission, 700 . East Evergreen Boulevard, Vancouver, WA 9866,.

3- U. S. Department of Commerce, Bureau of Census, Annual Survey of Manufactures 1975: Fuels and Energy Consumed, Statjstics for the United States M75(AS) -4 (September 1977).

4- U. S. Department of Commerce, Bureau of Census, Annual Survey of Manufactures 1976: Fuels and Energy Consumed, States, by Industry Group, M76 (AS) -4.2 (May 1978).

Idaho

5- Department of Water Resources and Boise State University, Population and Employment Forecast - State of Idaho: Baseline Projection 7975-2000 IPEF73 (Ju1y 1976).

6- J. Gerick, Idaho Potential for Industrial Utilization of Geothermal Energy, Unpulished thesis, University of Idaho, Moscow (November 1976).

7- Energy Facts: Idaho - United States - World, Idaho State Office of Energy (May 25, 1977).

8- Mathematical Sciences Northwest, Inc., Northwest Energy Policy Project Energy Demand Modeling and Forecasting, Final Report, (1977) (Available from Northwest Energy Policy Project, 1096 Lloyd Building, 700 N. E. Mul tnomah Street, Portland, OR 97232).

Arizona

9- Arizona Statictical Review 3rd ed., Valley National Bank of Arizona (September 1977).

10- James E. Bailey, and Paul Russell, Arizona Energy Audit and Conservation Guide for Hotels and Motels, Upuublished document from the College of Engineering, Arizona State University.

11- Helmut J. Frank, Arizona Energy Inventory: 1977, A Report on the State's Energy Position and Outlook to 1985, Office of Economic Planning and Development of State of Arizona (February 1977). 
12- Helmut J. Frank, Arizona Energy Inventory: 1977, A Report on the States Position and Outlook to 1985 (Executive Summary), Office of Economic Planning and Development of State of Arizona (February 1977).

13- 1978 Funding Proposal for the State Conservation Program PL-94-163 and Supplemental Conservation Program PL-94-385, Office of the Governor of Arizona and Office of Economic Planning and Development (January 1978).

Colorado

14- Future Energy Alternatives for Colorado, 1, Colorado Energy Research Institute (January 1976).

15- Department of Mineral Economics, Colorado School of Mines, Economic Impact of Alternative Supply Policies in Colorado, Department of Mineral Resources, Colorado School of Mines (1974).

16- David H. Hebb, (ed.), "Economic Impact of Alternative Energy Supply Policies in Colorado: A Summary Report," Quarterly of the Colorado School of Mines, 70, (Apri1 1975) pp. -

17- Thirteenth Annual Colorado Business-Economic Outlook Forum 1978. University of Colorado College of Business and Administration and Colorado Division of Commerce and Development (December 1977).

18- "Unpublished figures on residential, commercial and industrial energy use." Private Communication with State of Colorado Office of Energy Conservation, Denver (January 1978).

Montana

19- A Need for Balance: Montana Energy and Growth Policies, Montana Energy Advisory Council (January 1977).

20- Theodore H. Clack, Jr., Montana Energy Position Paper: A Montana Energy Advisory Council Staff Report, Montana Energy Advisory Council (June 1976).

21- Coal Development Information Packet, Montana Energy Advisory Council (December 1974).

22- Coal Development Information Packet (Supplement 1), Montana Energy Advisory Council (July 1975).

23- John W. Duffield and Richard Stroup, Projections of Natural Gas and Electricity Prices in Western Montana (Executive Summary), Montana Energy Advisory Council (January 1977).

24- Itami, Rich, Montana Historical Energy Statistics, Montana Energy Office (February 1978). 
25- John R. McBride, Coal Liquefaction: Technology, Impacts, and Technical, Suitability for Montana, Montana Energy Advisory Council (September 1976).

26- Nancy B. McLane, (comp.), Directory of Montana Energy Research and Development Projects, Montana Energy Office (January 1978).

27- Richard Stroup, Projecting Natural Gas Prices in Western Montana, Montana Energy Advisory Counci1 (January 1977).

28- Terry Wheeling, Montana Historical Energy Statistics, Montana Energy Advisory Council (September 1976).

Nevada

29- David L. Mendive, Energy in Nevada: A Summary of Historical Energy Consumption and Projections of Future Energy Consumption, Office of the State Planning Coordinator State of Nevado (September 1976).

New Mexico

30- Emery C. Arnold, et al, New Mexico's Energy Resources ' 77 New Mexico Bureau of. Mines and Mineral Resources State Geoligist Arailan, 167 (January 1978).

31- State Energy Conservation Plan for New Mexico, Conservation Division Energy Resources Board (July 1977).

32- Statistical Year Book of the Electric Utility Industry for 1976, Edison ETectric Institute (1976).

South Dakota

33- R. Freeman and R. Meier, Potential Application of Madison Formation Waters for Community Heating - South Dakota, QM-78-042, Johns Hopkins University, Applied Physics Laboratory (Apri1 28, 1978).

34- Robert A. Schoon and Duncan J. McGregor, Geothermal Potentials in South Dakota, South Dakota Geological Survey Report of Investigations, 110 (1974).

35- South Dakota Energy Conservation Policy Plan, South Dakota Office of Energy Policy (May 1977).

Private Communication with South Dakota Office of Energy Policy (1978).

$\underline{\text { Utah }}$

36- Rodney D. Millar and Reed T. Searle, Utah Energy, Office of Legislative Research Report 8 (December 1976). 
37- Utah Energy Office, The 1978 Program for Energy Conservation in Utah, Salt Lake City, Utah: Legislative Printing Office c. 1978).

Wyoming

38- Jean C. Ackerman, The Rate Also Rises: An Analys is of Electric \& Natural Gas Utilities in Wyoming, Laramie, WY: Community Action of Laramie County, Inc. (1977).

39- Roy M. Brechenridge and Bern S. Hinckley, Thermal Springs of Wyoming, Wyoming Geological Survey Bulletin, (March 1978).

40- Theodore D. Browne and-Edward F. Harvey, Wyoming Energy Consumption: Minera ls, Fuels, Electrical Generation and Agricultural Sectors, Bicket of Economic Manning and Development.

41- Edward R. Decker, Geothermal Resources, Present and Future Demand for Power \& Legislation in the State of Wyoming, Geological Survey of Wyoming Public Information Series, 1.

42- David D. Freudenthal, Peter Recciardelli and Michael N. York, Coal Development Alternatives: An Assessment of Water Use and Economic Implications, Wyoming Department of Economic Planning and Development (December 1974).

43- Gary B. Glass, comp., Wyoming Coal Directory, Geological Survey of Wyoming Public Information Series, 5.

44- John T. Goodier, Dale S. Hoffman and Jackie Basset, 1977 Wyoming Mineral Yearbook, Mineral Division State Department of Economic Planning and Development (January 1978).

45- John T. Goodier, Wyoming Mineral Industry and Problems of Taxation, Regulatory Restrictions and Business Climate, Department of Economic Planning and Development (December 1977).

46- Edward F. Harvey, An Analys is of Energy Consumption in Wyoming, Bicket, Browne, Coddington \& Associates, Inc. (December 1975) (available from Wyoming Department of Economic Planning and Development).

47- Donald W. Lane, Forest K. Root and Gary B. Glass, Energy Resource Map of: Wyoming, Geological Survey of Wyoming (1975).

48- Rules and Regulations Governing the Issuance of Geothermal Resource Permits and Leases, Wyoming State Land Office (November 1, 1975).

49- Temperature Gradient Maps of Wyoming, Geological Survey of Wyoming (1976).

50- Wyoming Energy Conservation Plan, Wyoming Planning Coordinator's Office (March 28, 1977). 


\section{RESOURCES}

The Rocky Mountain Basin and Range region contains abundant hydrothermal resources, but little use is presently being made of these resources. Electrical power generation is planned from a hot water reservoir at Roosevelt Hot Springs, Utah, and other reservoirs capable of power generation are known in Nevada and New Mexico. Lower-temperature resources are being used for space heating in Idaho, Montana, Nevada, and South Dakota, and for balynology and small miscellaneous uses throughout the region.

Following is a discussion of the hydrothermat resources available in each of the states in the region. Our present knowledge of the resource base is scanty, but is being rapidly upgraded. It is apparent that the potential for new discovery in the region is great.

Figure 36 shows each of the ten regional states and the boundaries of the physiographic provinces. Because each province can be expected to contain a particular suite of resource types, it is helpful to consider the resources within each state in their regional context. In the following discussion, the known resources are grouped into those of high temperature $\left(T>150^{\circ} \mathrm{C}\right)$ and those of low and moderate temperature $\left(T \leq 150^{\circ} \mathrm{C}\right)$. 


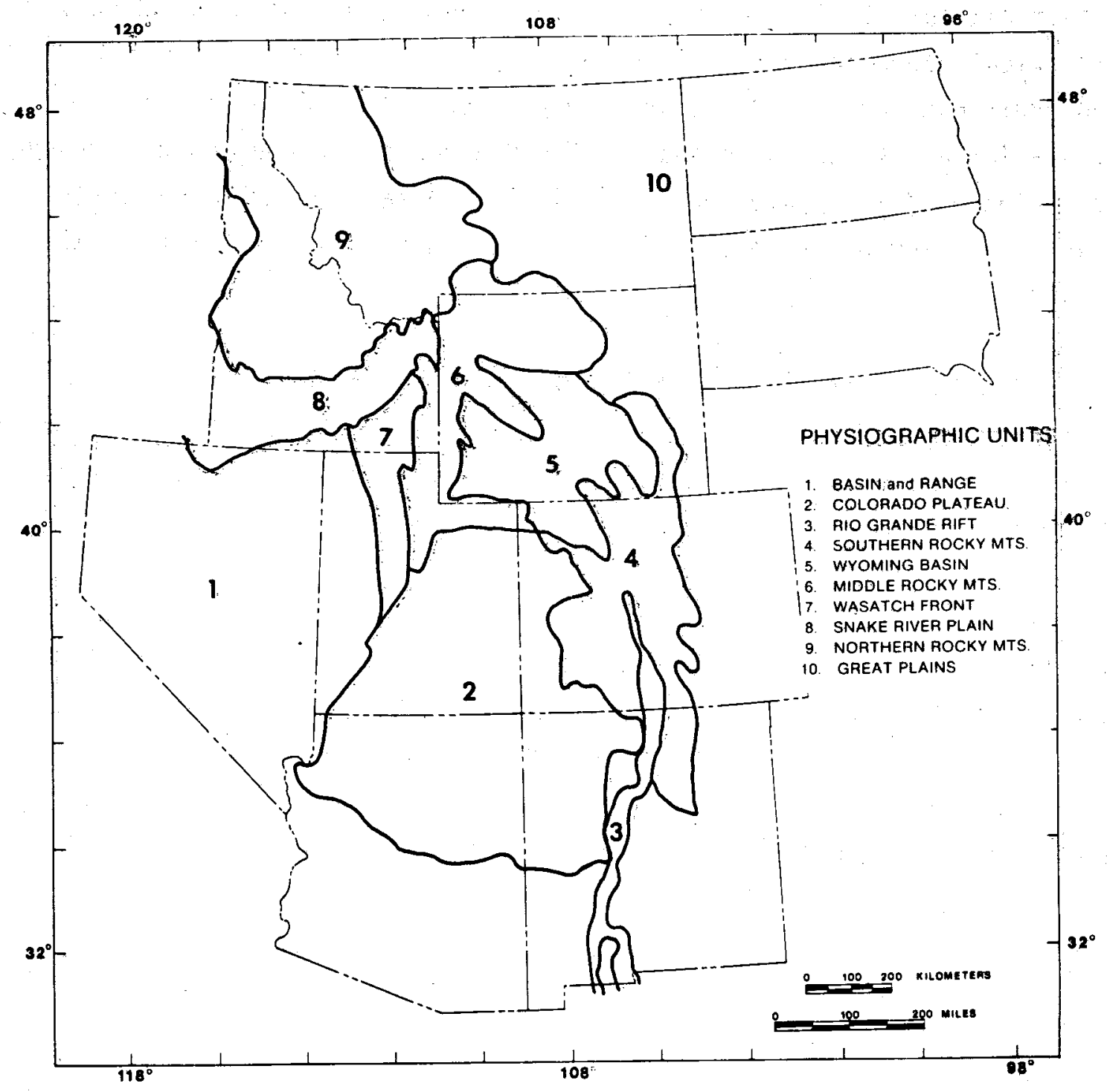

Fig. 36 Physiographic Provinces. 


\section{ARIZONA}

\section{Introduction}

Two geologic provinces are recognized in Arizona: the Basin and Range province and the Colorado Plateau province (see Figure 36 ). Southern, western, and extreme northwestern Arizona are located in the Basin and Range province, which consists of northward- or northwestward-trending mountain blocks separated by flat, alluvial-filled intermontane basins that have a valley floor elevation of 300 to 800 meters. The mountains generally have been uplifted by range-front faulting relative to the basins. Valley areas are typically underlain by several thousand meters of consolidated to relatively unconsolidated sediments from erosion of the mountain blocks. Rocks exposed in the ranges include intrusive, extrusive, metamorphic, and sedimentary types, which are typically folded and faulted, and which range in age from Precambrian to Recent.

Northern Arizona is in the Colorado Plateau province. This is an area of flat-lying sedimentary rocks that form plateaus having typical elevations of 1,700 meters above mean sea level. Lack of geologic complexity indicates that the plateau has been relatively stable in the geologic past, although the plateau margins have been active.

Although no areas of fumarolic or geyser activity are known to exist, there are several areas of basaltic and rhyolitic volcanism less than 3 million years old. Four of these occur in the Basin and Range province: in the San Bernardino valley at the extreme southeast, in an area about 50 kilometers southeast of Safford, in an area 30 kilometers west of Gila Bend, and in the Pinacate lava field 100 kilometers southeast of Yuma. Three areas of young basaltic volcanism occur in the Colorado Plateau: near Springerville in the east-central part of the state, near Flagstaff, and in the extreme northwest. 
Other indications of hydrothermal resources include a large number of anomalously warm wells and springs, mainly in the Basin and Range portion of the state. There are also several areas of unusually high heat flow, and many areas contain anomalous geochemical thermometers.

High-Temperature Resources (see Figure 37)

\section{Confirmed Reservoirs: None.}

Prospects: Little drilling has been done for hydrothermal resources in Arizona, and only three deep hydrothermal holes have been attempted. The following table shows the temperature and depth of water in a number of wells:

\section{TABLE IV}

WATER TEMPERATURES IN ARIZONA WELLS ${ }^{[1]}$

\begin{tabular}{llcc}
\hline \multicolumn{1}{c}{ Name } & Location & Temperature $\left({ }^{\circ} \mathrm{C}\right)$ & Depth $(\mathrm{m})$ \\
Chandler & T2S R6E & 120 & 2781 \\
La Planta & T7S R8E & .120 & 3186 \\
Picacho & T8S R8E & 113 & 2440 \\
Tucson South & T16S R5E & 147 & 3830 \\
San Simon & T13S R30E & $134(?)$ & 1951 \\
\hline
\end{tabular}

Other wells have encountered water at elevated temperatures less than $100^{\circ} \mathrm{C}$. These wells have all been drilled in the valley areas, and no systematic hydrothermal prospecting has yet been done in any of the areas of recent volcanism. 


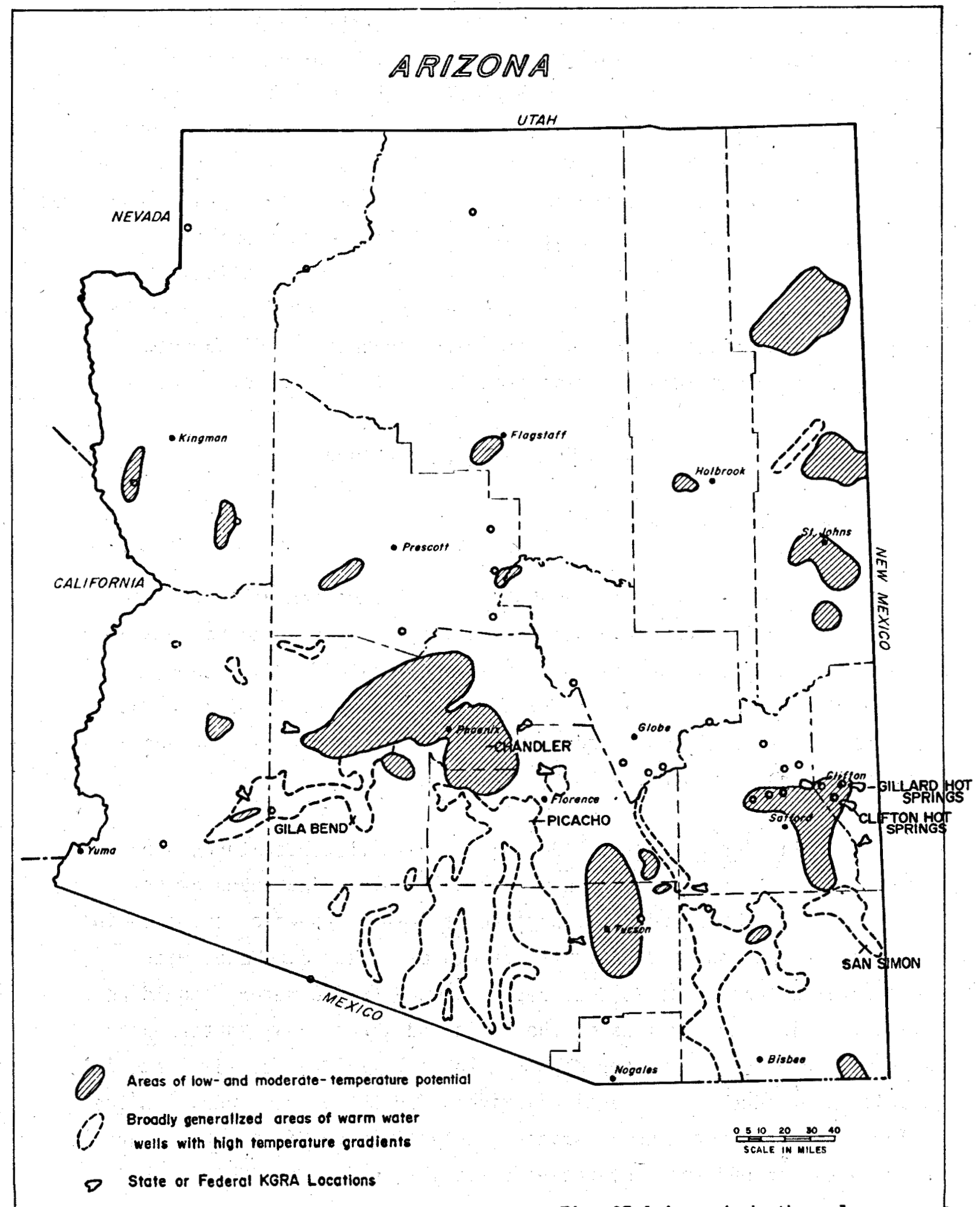

o. Hot Springs

Fig. 37 Arizona hydrothermal resources. (atter Geothermal Mop No.1, Ariz. Bureau of Geology and Mineral Tectinology) 
Potential for Discovery. There are relatively few petroleum test wells in Arizona. Petroleum Information Corp. lists only 850 wells in their computer files, whereas about 106,000 wells have been drilled just in the Permian Basin of western Texas and eastern New Mexico. A number of areas are known which have anomalously high geothermal gradients or heat flow, and geachemical thermometers indicate anamalously high subsurface temperatures at a number of locations. [2] It has been thought that Arizona has little hydrothermal potential, but recent work indicates otherwise. It now appears fair to say that one or more reservoirs hot enough for electrical power generation will probably be discovered, especially if economic generation from $150^{\circ} \mathrm{C}$ of water becomes feasible.

Low- and Moderate-Temperature Resources (see Figure 37)

Confirmed Reservoirs: None.

Prospects: Numerous anomalously warm springs and wells $\left(\mathrm{T}>30^{\circ} \mathrm{C}\right)$ are located in Arizona. They occur mainly in the Basin and Range province. Large areas having warm water potential are located near Phoenix, Tucson, and Safford. In addition, there are prospects at Castle Hot Springs, Florence, San Bernardino Valley, Clifton-Morenci, SpringsvilleSt. Johns, and elsewhere.

Potential for Discovery. Data on water-well temperatures are currently being compiled, and new warm wells are being added almost daily. In the Basin and Range portion of Arizona, deep circulation in the many range-front and basin faults can be expected. Water with temperatures from 30 to $90^{\circ} \mathrm{C}$ at depths from 0 to 500 meters should be discovered in many portions of the Basin and Range, and, hotter water also will be found at deeper depths. The alluvial valley fill material should form large and productive aquifers for these resources. In the Colorado Plateau portions of Arizona, patential for discovery appears to be greatest around areas of recent volicanism. 


\section{COLORADO}

\section{Introduction}

Colorado is divided geologically. into three distinct provinces: the Colorado Plateau in the western portion of the state, the Southern Rocky Mountains in the west-central part of the state, and the Great Plains in the eastern half of the state (Figure 36 ). The Colorado Plateau is a geological stable area of flat-lying sedimentary rocks with areas of intrusive activity which has long since cooled. A number of young, silicic volcanic system occur along the plateau margins. The southern Rocky Mountains are composed of uplifted, faulted and folded rocks, terminating to the east in the Front Range. Eastward lies the Great Plains, a flat area of erosional material which covers older rocks. Essentially all of the 56 known thermal areas in Colorado are located within the Colorado Plateau and Southern Rocky Mountain provinces.

The greatest potential for finding high-temperature hydrothermal systems is at the margin of the Colorado Plateau, where a number of young silicic volcanic systems are located. Other areas appear to have minimal potential. The interior of the Colorado Plateau is thought to have relatively low heat flow and to lack surface thermal manifestations. The Great Plains area has low hydrothermal potential. This area contains no identified igneous rocks or other encouraging geologic information. Heat flow throughout the region is normal or near-normal, reducing the potential for moderate-temperature convective systems.

\section{High-Temperature Resources}

Confirmed Reservoirs: None.

Prospects: Three sites are good prospects for electric development by 1985. These are Mount Princeton, Poncha Hot Springs, and Cebolla Hot Springs. 
Potential for Discovery. There is potential along the margin of. the Colorado Plateau.

Low- and Moderate-Temperature Resources. (see Figure 38).

Cönfirmed Reservoirs: None.

Prospects: Most of the moderate-temperature resources are located within the Southern Rocky Mountain province. Within this province, eight sites have been identified as potentially developable by 1985 . These are Haystack Butte, Ouray, Splashland and Sand Dune-San Luis Vałley, Shaws Hot Springs, Mineral/Valley View Hot Spring, Idaho Springs, and Cement Creek/Rangers Hot Springs. Two additional sites, Pagosa Springs and Glenwood Springs, are now undergoing preliminary planning for hydrothermal development.

Pottential for Discovery. Several other sites have hydrothermal potential, but do not appear developable by 1985. Calculations indicate there are 27 communities within Colorado which could be efficiently served with thermal water, resulting in the heating of over 16,000 . dwelling units. 


\section{IDAHO}

\section{Introduction}

Five physiographic provinces occur in Idaho: the Snake River Plain, Northern Rocky Mountains, the Basin and Range, the Middle Rocky Mountains, and the Columbia Plateau (see Figure 36 ). Idaho is blessed with an abundance of shallow moderate- and low-temperature resources which are associated with faulting along the margins of the Snake River Plain and the Idaho Batholith of the Northern Rocky Mountains. The deeper, relatively undrilled Snake River Plains downwarp may contain high-temperature hydrothermal resources which are effectively concealed from surface exploration by the Snake River Plains aquifer, a high-flow rate, coldwater aquifer. The inventory of known thermal springs and wells by the U.S. Geological Survey and the Idaho Department of Water Resources is relatively complete. Industry interest is now focusing on the potential for production of high-temperature fluids from the Snake River Plain.

\section{High-Temperature Resources}

\section{Confirmed Reservoirs. None.}

Prospects. The northeastern Snake River Plain is a good prospect area. The age of the silicic volcanic rocks generaliy decreases from the western Snake River Plain towards Yellowstone National Park to the northeast. Sites around young rhyolitic occurrences in the eastern Snake River Plain, such as those in the Island Park caldera, constitute an attractive exploration target.

The Blackfoot volcanic field may also contain a high-temperature reservoir. This area in Bingham County contains silicic volcanic rock dated at less than 100,000 years Before Present. Surface evidence of hydrothermal activity is present, but not extensive. 
Potential for Discovery. Though a few other areas in the Snake River Plain, particularly in the east, may have high-temperature potential, most researchers expect the fluids to be cooler.

Low- and Moderate-Temperature Resources (see Figure 39)

Confirmed Reservoirs. The northern margin of the western Snake River Plain contains widely distributed low- to moderate-temperature hydrothermal fluids. Some Boise homes have been heated with hydrothermal water since before the turn of the century. This resource is associated with the bounding normal faults and their intersection with generally north-trending lineaments that are well defined throughout the Idaho Batholith. In the Boise area, potable water in the 50 to $80^{\circ} \mathrm{C}$ range is produced from depths of 120 to 370 meters. The wells utilized by the District Heating System have been operated since 1890 without visible decline in productivity. Exploration and development are accelerating.

In the Bruneau-Grandview-Oreana area, at the southwestern margin of the Snake River Plain, lies a $20 \times 100-k i l o m e t e r$ region of low-temperature resources. The waters have been used extensively for agriculture, primarily for alfalfa irrigation.

Another confirmed resource is the site of the Department of Energy's Raft River Facility. Three production wells have confirmed the presence of a moderate-temperature reservoir near Malta, in Cassia County. Additional hot wells north and west of the federal project indicate a hot-water resource of considerable geographic extent.

The production of shallow hot water for space heating is rapidly escalating in the Buhl-Melon Valley of southern Idaho. No detailed resource assessment work has been accomplished, but the bounds of the known producing area are being expanded by step-out drilling. 


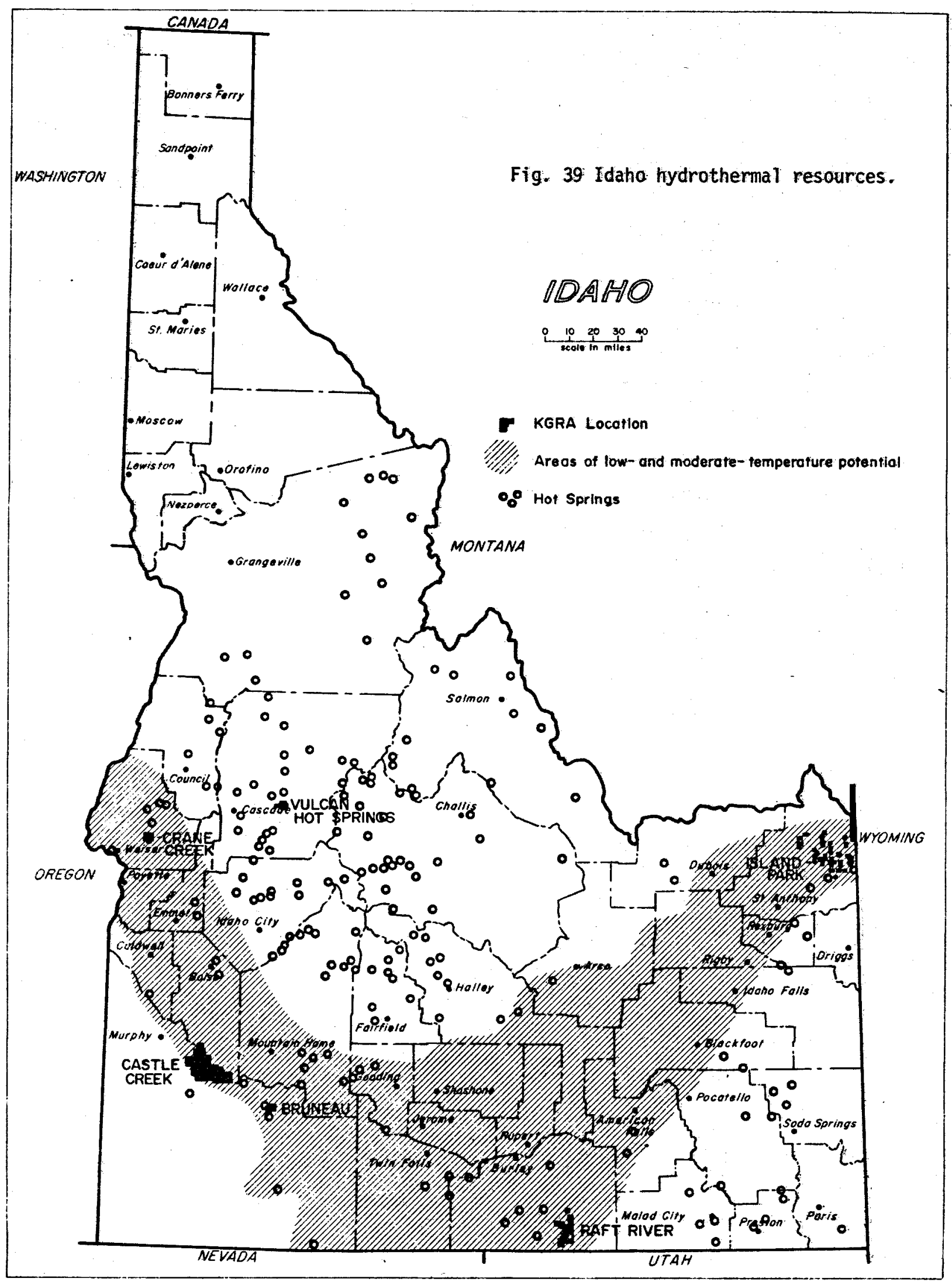


Prospects. Water-well drilling near Pocatello, in Bannock County, has encountered $60^{\circ} \mathrm{C}$ water at 300 meters. The area is attractive due to the probable coincidence of rapid residential growth, existing energyintensive industry (the phosphate industry) and low- to-moderatetemperature hydrothermal resources. Numerous warm springs occur in the mountainous areas of Idaho, but these areas are generally unpopulated. It has been reported that petroleum test wells in the overthrust belt of western Wyoming and extreme eastern Idaho have occasionally encountered anomalously warm water.

Potential for Discovery. Discovery potential is large for low- and moderate-temperature resources, especially in the southern portion of the state. 
MONTANA

\section{Introduction}

Three physiographic provinces occur in Montana, the Northern Rocky Mountains, the Middle Rocky Mountains, and the Great Plains. The Rocky Mountains Provinces are composed of faulted and folded sedimentary rocks and intrusions which form mountain blocks with intermontane basins. The Boulder Batholith in southwestern Montana is a large intrusion which has been dated at 68 to 74 million years before present. Southwestern Montana contains a broad area with higher-than-normal heat flow and with numerous hot springs. Geochemical indicators and observed well and spring temperatures suggest mainly low- or moderate-temperature reservoirs best suited for direct heat applications. In the eastern portion of the state, the Madison aquifer contains hot water whose potential for directheat uses has not been determined.

\section{High-Temperature Resources}

\section{Confirmed Reservoirs. None.}

Prospects. The only known area in the state with a geologic environment typical of high-temperature hydrothermal sites is the region immediately adjacent to Yellowstone National Park. The West Yellowstone and Gardiner areas have attracted industry interest, but no exploratory drilling has occurred to date.

Potential for Discovery. Moderate discovery potential exists for high-temperature systems in the Yellowstone area. Blind potential (1acking in surface manifestations) exist as indicated by the discovery of moderate-temperature water at Marysville. 


\section{Low- and Moderate-Temperature Resources (see Figure 40)}

Confirmed Reservoirs. The following areas have sufficient data available to suggest that direct-heat utilization will soon be installed or expanded:

- Hunter's Spring - present agricultural applications

- White Sulphur Springs - space heating

- Warm Springs - space heating

- Fairmont - agricultural uses

- Silver Star - agricultural and space heating

- Bozeman Hot Springs - recreation and space heating

- Boulder - agricultural, recreation and space heating

- $\quad$ - Broadwater - agricultural and space heating

Prospects. Deep irrigation wells in the Madison aquifer in eastern and southeastern Montana produce warm water that is suitable for low-temperature direct-heat applications. The magnitude of this potential resource is under investigation by the state's Bureau of Mines and Geology.

Potential for Discovery. Because of the numerous hot springs, potential for yet undiscovered low- and moderate-temperature hydrothermal resources appears to be good. 

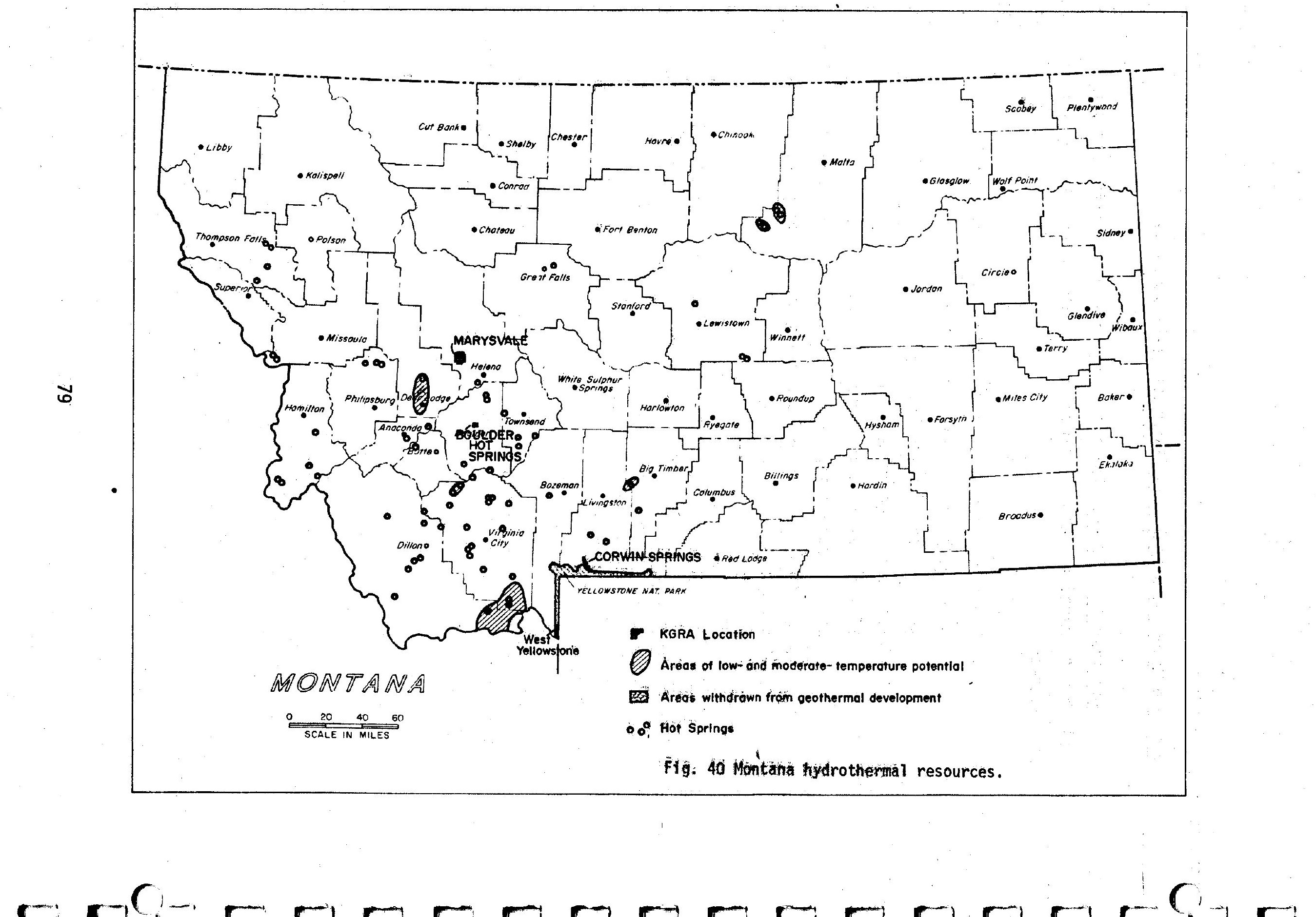


\section{NEVADA}

\section{Introduction}

Nevada lies almost wholly within the Basin and Range physiographic province (see Figure 36). This province is characterized by northwardtrending mountain blocks separated by alluvial-filled basins. The mountain and valley blocks are separated by faults that have as much as 3,000 meters of vertical displacement. Deeply-circulating water along some of these faults is believed to be the source of the many warm springs and wells, especially in the northern half of the state: Several areas are known to contain young volcanic rocks, and other such areas may yet be found. At least two known hydrothermal systems (Steamboat Springs and Silver Peak) are believed to be related to igneous activity (see Figure 41). Although heat flow throughout the tectonically active Basin and Range province is high, northern Nevada contains an area of especially high heat flow called the Battle Mountain Heat-Flow High. In addition, northern Nevada contains a number of springs and wells whose geochemical thermometry indicates high reservoir temperatures. There are 30 KGRAs in Nevada, and more than 300 potential hydrothermal sites.

Hydrothermal exploration by industry has been very active in Nevada, especially since about 1974. Approximately 30 companies are now actively exploring in Nevada.

\section{High-Temperature Resources (see Figure 41)}

Confirmed Reservoirs: One reservoir is confirmed, at Desert Peak in the Brady-Hazen KGRA. Phillips Petroleum and Sierra Pacific Power Company are presently negotiating for development of electric generation in this area. 


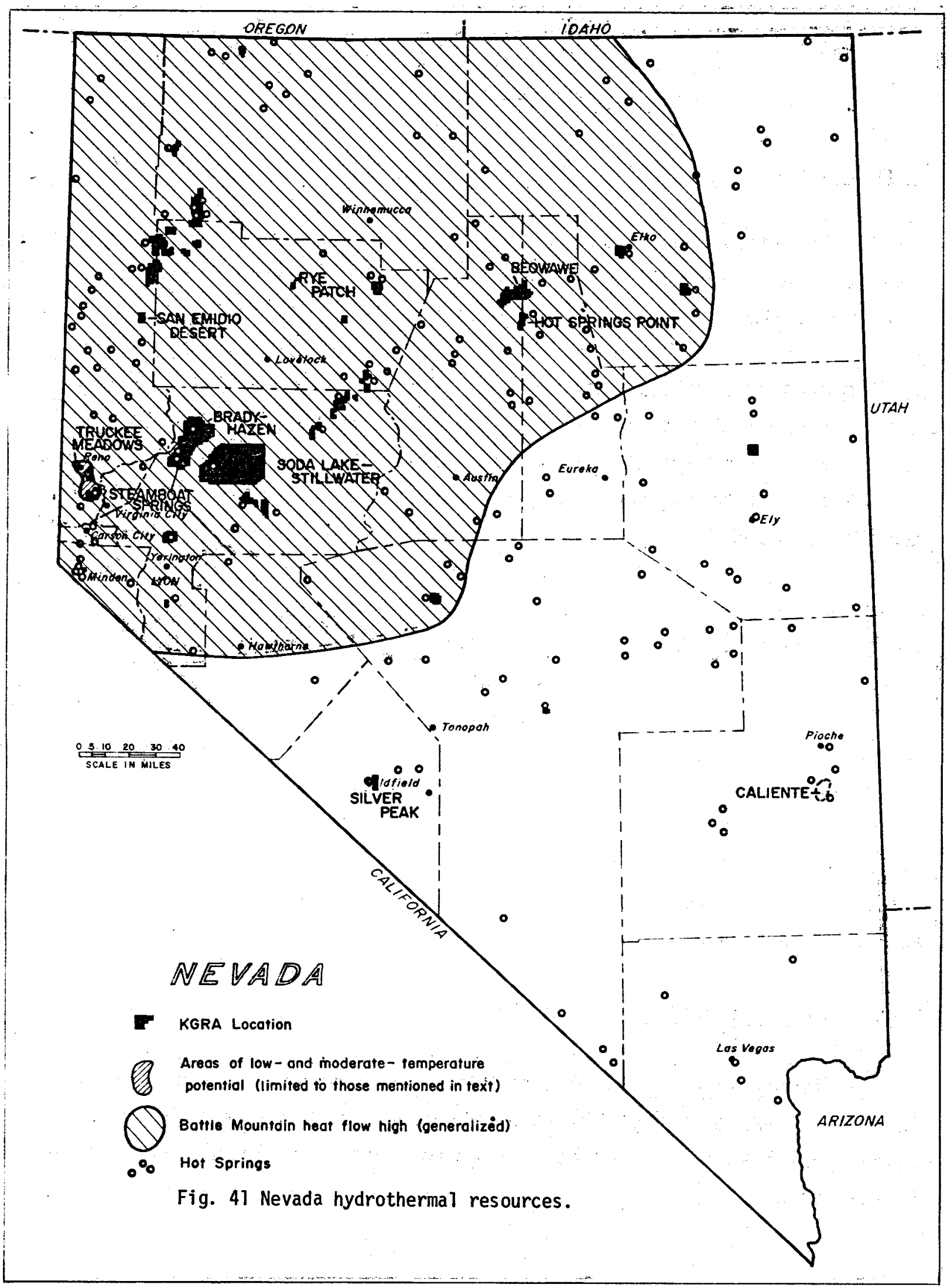


Prospects: Beowawe and Steamboat Hot Springs are areas presently believed to have a potential for electric power generation. A number of other highly prospective areas include Soda Lake-Stillwater, Hot Springs Point, Humboldt (Rye Patch), and San Emidio Desert.

Potential for Discovery: The potential for additional discovery seems to be greatest in northern Nevada. Recent drilling by Phillips Petroleum Co. at Humboldt House, outside of the Rye Patch KGRA, indicates that new systems with surface manifestations remain to be discovered. Northern Nevada is an area of high average heat flow, it is tectonically active, and it has a relatively large number of springs and wells with high-temperature geochemical thermometer results.

\section{Low- and Moderate-Temperature Resources (see Figure 41)}

Confirmed Reservoirs: Four confirmed reservoirs exist in Nevada. Sixty homes, two churches, and two motels currently use hydrothermal waters for space heating in Reno, and the reservoir can probably support a much larger system. A food-dehydration plant is currently under construction at Brady's Hot Springs, under support of the Geothermal Loan Guarantee program. At Caliente, a space-heating system at a trailer park is being expanded. In the Fallon area some ranches are heated by hydrothermal water.

\section{Prospects: Attractive prospects for direct-heat hydrothermal} development exist around each of the KGRAs and in the numerous areas of warm springs and wells.

Potential for Discovery: Potential for discovery is greatest in northern Nevada, where the majority of the prospects are known, and where high heat flow and high geochemical thermometry results have been found. The many range-front faults are also good prospects, because they often form conduits for the deep circulation of meteoric water. 


\section{NEW MEXICO}

\section{Introduction}

Over one hundred known thermal springs and wells are found in New Mexico. They are concentrated in the Rio Grande Rift and the southwestern portion of the state. Both areas exhibit characteristics that indicate geothermal potential, including active extensional tectonics, recently active volcanism, active seismicity, high heat flow, young hydrothermal mineral deposits, and numerous hot springs and wells.

The Rio Grande Rift is about 850 kilometers long, extending from Leadville, Colorado, to southern New Mexico. The rift zone is composed of a series of en-echelon north-trending grabens and half-grabens; the regional extension is thought to have begun about 29 million years ago.

The Rio Grande Rift either borders, crosses, or merges with the four geologic provinces recognized in New Mexico: the Southern Rocky Mountains, the Colorado Plateau, the Great Plains, and the Basin and Range provinces. The northern segment of the Rio Grande Rift passes through an extension of the Southern Rocky Mountains and partially adjoins the Colorado Plateau on the west. To the east of the rift lies the stable Great Plains province. The southern part of the rift is bounded on the west by the Colorado Plateau and the Basin and Range provinces. Some researchers consider the Southern Rio Grande Rift to merge completely into the Basin and Range Province. Structural relief between the grabens and halfgrabens of the Rio Grande Rift and the bounding uplifts varies from only 100 to over 8,000 meters in some deeper basins. Abundant fault scarps with varing degrees of exposure are common along the length of the rift. Many are covered by basin fill or thinner pediment and terrace deposits. 
The Rio Grande Rift and adjacent regions have been the site of volcanic activity through most of the Cenozoic era. The first large-scale volcanism along this zone produced the extensive pre-rift Datil-Mogollon andesite fields (Figure 42). Volcanism concurrent with rifting began about 20 to 26 million years ago and has been predominately located along the middle and western parts of the rift. Basaltic andesites were most abundant during this stage; true basalts were more common later, especially from about 5 million years ago to the present. Large volcanic centers began to develop about 12 to 14 million years ago, where major northeasttrending crustal lineaments intersected the rift. These formed the Jemez Mountains (Springerville-Raton lineament) and Socorro and Magdelena Peaks (Morenci-Magdalena Tineament), which exhibit a bimodal basaltrhyolite volcanism. Tholeiitic flood basalts extruded along the rift axis in northern New Mexico in the last million years. They are interpreted as having been generated from an upwarped mantle, although their occurrence outside the axial graben has also been documented. In particular, there is a chain of Quaternary basalts trending northeastward from the Mt. Taylor volcanic system, across the rift and along the SpringervilleRaton lineament. The youngest volcanic rocks in New Mexico (s 10,000 years old) occur along this 1 ineament (McCartys and Capul in basalts), and at one location to the east of the Rio Grande Rift, near the center of the state (Carrizozo basalts).

Hot-spring activity in New Mexico generally corresponds to the regions of young volcanism and high heat flow (>2.5 HFU). These high heat flows: coincide with the entire western part of the Rio Grande Rift; define an area in the vicinity of the McCartys basalt; and encompass a region in southwestern New Mexico and southeastern Arizona. A portion of the high heat flow ribbon along the western margin of the rift overlies an area near Socorro, where an extensive (> 1700 square kilometers) sill-iike magma body is located at a depth of 18 kilometers as indicated from macro-earthquake studies. 


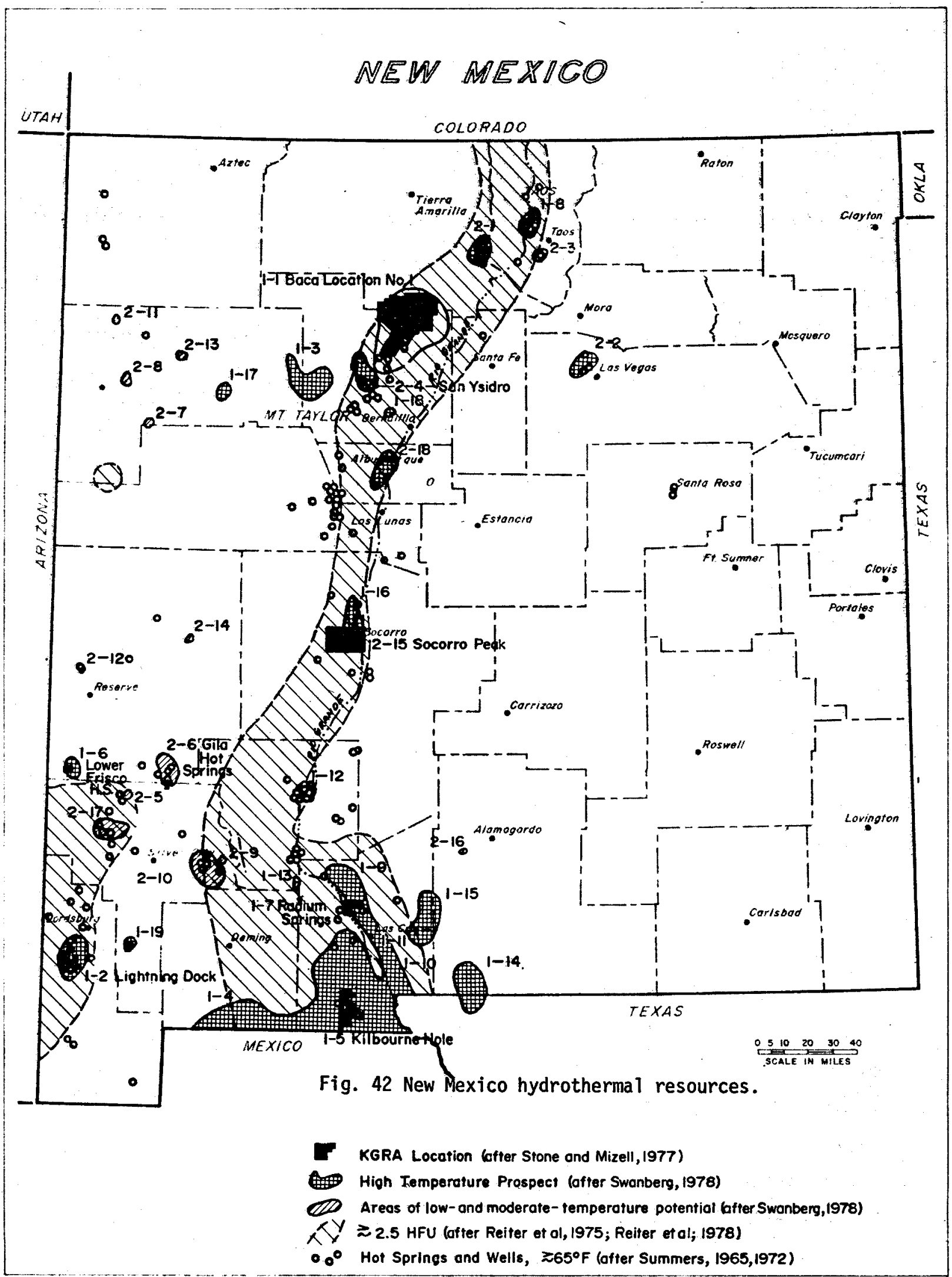


In southwestern New Mexico the thermal anomaly is associated with northtrending Basin and Range structures. There is widespread Quaternary basaltic volcanism in this region, as well as older (pre-Basin and Range) silicic volcanic rocks. One of New Mexico's two positively identified hydrothermal resources above $100^{\circ} \mathrm{C}$ occurs in this area (Table IV). Boilung water was first encountered here in 1948, in the Animas Valley, at a depth of less than 30 meters. This is now the Lightning Dock KGRA.

The U.S. Geological Survey has designated eight KGRAs in New Mexico, for a total of 1327 square kilometers. These sites are the Baca Location No. 1, San Ysidro, Socorro Peak, Lower Frisco Hot Springs, Gila Hot Springs, Radium Springs, Kilbourne HoTe, and Lightning Dock (see Figure 42 ).

High-Temperature Resources (see Figure 42)

Confirmed Reservoirs: The Valles Caldera (Baca Location No. 1 KGRA) is the only confirmed high-temperature resource in New Mexico. Union 0 il Company has developed this site $\left(35^{\circ} 53^{\prime}\right.$ north latitude, $106^{\circ}$ $35^{\prime}$ west longitude) in the Jemez Mountains for several years. Twelve wells have been drilled by Union to depths ranging from 1220 to 2745 meters. Six producing wells are currently listed, with bottom-hole temperatures ranging from 260 to $315^{\circ} \mathrm{C}$. The subsurface reservoir is estimated to be 130 cubic kilometers in size and to contain 3.1 cubic kilometers of water averaging 7000 parts per million total dissolved solids. The electrical-energy potential of the reservoir is conservatively estimated to be $400 \mathrm{MW}$ for 30 years, and is liberally estimated at 1,942 MW for 30 years. Union 0 il Company and the Public Service Company of New Mexico submitted a proposal to the Department of Energy on January 31 , 1978, seeking partial funding to build a 50MWe demonstration power plant to be on line by 1982 . 
Prospects: A large number of high-temperature prospects have been identified in New Mexico from geochemical analyses of springs and wel1s. [8] These locations are 1 isted in Table $v$, along with the pertinent temperature data.

Potential for Discovery: Good potential exists for the discovery of additional high-temperature resources in New Mexico. They should be located in the western half of the state, particularly along the Rio Grande Rift or in the Basin and Range province in the southwest.

Low- and Moderate-Temperature Resources (see Figure 42)

Confirmed Reservoirs: Many springs and wells in New Mexico exhibit surface temperatures in the low-to-moderate range. Sufficient data have yet to be compiled, however, for reservoir confirmation.

Prospects: There are many low-and-moderate temperature prospects in New Mexico. Table VI 7 ists the prospects identified by actual surface temperature measurements from springs or we17s.

Potential for Discovery: In a broad sense one may consider all of New Mexico, exclusive of roughly the northeastern corner of the state, as having potential for the discovery of low- and moderate-temperature geothermal resources. The discovery of economic moderate-temperature resources is less likely in the northwestern section of the state, in the Colorado Plateau province, and in the Great Plains province. 
TABLE V

NEW MEXICO HIGH-TEMPERATURE RESOURCE PROSPECTS [8]

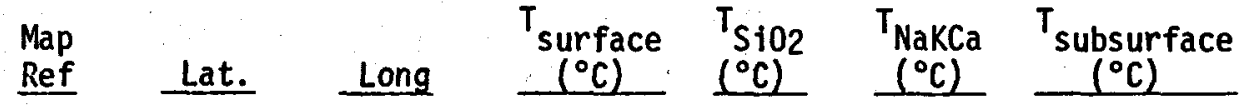

Areas Sampled:

\begin{tabular}{|c|c|c|c|c|c|c|c|}
\hline Baca Location No. 1 & $1-1$ & $35^{\circ} 43^{\circ} !$ & $106^{\circ} 32^{\prime}$ & 87 & 177 & 234 & 240 \\
\hline Lightning Dock 1 & $1-2$ & $32^{\circ} 08.5^{\prime}$ & $108^{\circ} 50^{\prime}$ & 99 & 160 & 167 & 170 \\
\hline Guadalupe Area & $1-3$ & $35^{\circ} 30^{\prime}$ & $107^{\circ} 15^{\prime}$ & 35 & 156 & 177 & 170 \\
\hline Columbus Area & $1-4$ & $31^{\circ} 45^{\prime}$ & $107^{\circ} 30^{\prime}$ & 31 & 135 & 195 & $155^{2}$ \\
\hline Kilbourne Hole ${ }^{1}$ & $1-5$ & $31^{\circ} 45^{\prime}$ & $106^{\circ} 50^{\prime}$ & 28 & 133 & 200 & $155^{2}$ \\
\hline Lower Frisco H.S. 1 & $1-6$ & $33^{\circ} 15^{\prime}$ & $108^{\circ} 47^{\prime}$ & 49 & 132 & 148 & 150 \\
\hline Radium S. 1 & $1-7$ & $32^{\circ} 30^{\prime}$ & $106^{\circ} 55.5^{\prime}$ & 53 & 118 & 223 & $130^{2}$ \\
\hline Mamby's H.S. & $1-8$ & $36^{\circ} 31.6^{\prime}$ & $105^{\circ} 40.6^{\prime}$ & 41 & 116 & 168 & $125^{2}$ \\
\hline San Diego Mountain & $1-9$ & $32^{\circ} 38^{\prime}$ & $106^{\circ} 58^{\prime}$ & warm & 105 & 233 & $125^{2}$ \\
\hline Mesquite-Berino & $1-10$ & $32^{\circ} 10.0^{\circ}$ & $106^{\circ} 40.0^{\prime}$ & 31 & 112 & 175 & $120^{2}$ \\
\hline Las Alturas & $1-11$ & $32^{\circ} 15.0^{\prime}$ & $106^{\circ} 46.0^{\prime}$ & 43 & 109 & 179 & $120^{2}$ \\
\hline Truth or Consequences & $1-12$ & $33^{\circ} 08.1^{\prime}$ & $107^{\circ} 15.2^{\prime}$ & 45 & 96 & 180 & $100^{2}$ \\
\hline Derry Spring & $1-13$ & $32^{\circ} 47.6^{\prime}$ & $107^{\circ} 16.6^{\prime}$ & 33 & 83 & 156 & $100^{2}$ \\
\hline
\end{tabular}

Areas from WATSTORE:

Southern Tulsarosa

Bas in

$1-14.32^{\circ} 05^{\prime} \quad 106^{\circ} 05^{\prime} \quad 71$

150

White Sands (Town)

$1-15 \quad 32^{\circ} 25^{\prime} \quad 106^{\circ} 25^{\prime} \quad 54$

114

160

150

North of Socorro

$1-16$

$34^{\circ} 20^{\prime}$

$106^{\circ} 50^{\prime}$

110

166

150

Prewitt Area

$1-17$

$35^{\circ} 26^{\prime}$

$107^{\circ} 53.0^{\prime} \quad 46$

100

150

Jemez Reservoir

$1-18$

$106^{\circ} 40^{\prime}$

$106^{\circ} 40^{\prime}$ warm

200

150

Lordsburg

$1-19$

$32^{\circ} 13.7^{\prime} \quad 108^{\circ} 30.7^{\prime} \quad 33$

120

150

150

1. KGRA

2 Estimated subsurface temperature in the $150-200^{\circ} \mathrm{C}$ rance if mixing models are applied to the silica data. 


\section{TABLE VI}

NEW MEXICO LOW-AND MODERATE TEMPERATURE RESOURCE PROSPECTS[8]

\begin{tabular}{|c|c|c|c|c|c|c|c|}
\hline & $\begin{array}{l}\text { Map } \\
\text { Ref } \\
\end{array}$ & Lat. & Long & $\begin{array}{c}\text { surface } \\
\left({ }^{\circ} \mathrm{C}\right)\end{array}$ & $\begin{array}{l}\mathrm{T}_{\mathrm{SiO} 2} \\
\left({ }^{\circ} \mathrm{C}\right) \\
\end{array}$ & $\begin{array}{l}\mathrm{T} \text { NaKCa } \\
\left({ }^{\circ} \mathrm{C}\right) \\
\end{array}$ & $\begin{array}{c}\mathrm{T}_{\text {subsurface }} \\
\left({ }^{\circ} \mathrm{C}\right)\end{array}$ \\
\hline 0jo Caliente & $2-1$ & $36^{\circ} 18.3^{\prime}$ & $106^{\circ} 03.0^{\prime}$ & 56 & 122 & 161 & 130 \\
\hline Montezuma H.S. & $2-2$ & $35^{\circ} 39.2^{\prime}$ & $105^{\circ} 17.4^{\prime}$ & 59 & 122 & 140 & 130 \\
\hline Ponce de Leon & $2-3$ & $36^{\circ} 19.4^{\prime}$ & $105^{\circ} 36.5^{\prime}$ & 34 & 106 & 92 & 105 \\
\hline San Ysidro 1 & $2-4$ & $35^{\circ} 35^{\prime}$ & $106^{\circ} 50^{\prime}$ & 52 & 89 & 160 & 100 \\
\hline Turkey Creek H.S. & $2-5$ & $33^{\circ} 06.5^{\prime}$ & $108^{\circ} 29.0^{\prime}$ & 74 & 117 & 68 & L.T. \\
\hline Gila H.S. ${ }^{1}$ & $2-6$ & $33^{\circ} 10^{\prime}$ & $108^{\circ} 10^{\prime}$ & 66 & 129 & 77 & L.T. \\
\hline Closson & $2-7$ & $35^{\circ} 15.5^{\prime}$ & $108^{\circ} 19.4^{\prime}$ & 61 & 95 & 51 & L.T. \\
\hline Fort Wingate & $2-8$ & $35^{\circ} 30^{\prime}$ & $108^{\circ} 35^{i}$ & 61 & -- & -- & L.T. \\
\hline Mimbres H.S. & $2-9$ & $32^{\circ} 44.9^{\prime}$ & $107^{\circ} 50.1^{\prime}$ & 58 & 107 & 75 & L.T \\
\hline Faywood H.S. & $2-10$ & $32^{\circ} 33.3^{\prime}$ & $107^{\circ} 59.7^{\prime}$ & 54 & 97 & 78 & L.T. \\
\hline Tohatchi & $2-11$ & $35^{\circ} 55.3^{\prime}$ & $108^{\circ} 34.7^{\prime}$ & 39 & 66 & 82 & L.T. \\
\hline San Francisco H.S. & $2-12$ & $33^{\circ} 49.8^{\prime}$ & $108^{\circ} 47.9^{\prime}$ & 37 & 97 & 52 & L.T. \\
\hline Crown Point & $2-13$ & $35^{\circ} 41.6^{\prime}$ & $108^{\circ} 08.4^{\prime}$ & 37 & 60 & 80 & L.T. \\
\hline E. San Augustin Plain & $2-74$ & $34^{\circ} 00.5^{\prime}$ & $108^{\circ} 05.5^{\prime}$ & 35 & 108 & 53 & L.T. \\
\hline Socorro ${ }^{7}$ & $2-15$ & $34^{\circ} 05.0^{\prime}$ & $106^{\circ} 57.0^{\prime}$ & 34 & -61 & 72 & L.T. \\
\hline Garton Welt & $2-7.6$ & $32^{\circ} 46.8^{\prime}$ & $106^{\circ} 09.0^{\prime}$ & 34 & 63 & 100 & L.T. \\
\hline Cliff Area & $2-17$ & $32^{\circ} 52.6^{\prime}$ & $108^{\circ} 35.0^{\prime}$ & 31 & 85 & 53 & L.T. \\
\hline Albuquerque Area & $2-18$ & $35^{\circ} 05^{\prime}$ & $106^{\circ} 45^{\prime}$ & 30 & -- & -- & L.T. \\
\hline
\end{tabular}

KGRA. 


\section{NORTH DAKOTA}

\section{Introduction}

The principal feature of interest in terms of hydrothermal energy is the Madison formation aquifer, which occurs in the Williston Basin and elsewhere in western North Dakota. The Madison formation contains a regionally interconnected system of fracture- and solution-opening porosity which is recharged at Madison outcrops on the periphery of South Dakota's Black Hills. Water flowing into the Madison aquifer spreads outward and downward below the surface. In the Williston Basin the Madison is more than a thousand meters deep and contains waters up to about $80^{\circ} \mathrm{C}$ in temperature. Water quality is poor, due to the occurrence of evaporite beds in the upper part of the Madison in and near the Williston Basin. None of the Madison hydrothermal water is now being used in North Dakota. Our current understanding of the real extent and temperature of fluids in the Madison is poor, and no map is included.

\section{High-Temperature Resources}

Confirmed Reservoirs: None.

Prospects: None.

Potential for Discovery: Smal1.

Low- and Moderate-Temperature Resources

Confirmed Reservoirs: None.

Prospects: The Madison aquifer is an excellent prospect, and could perhaps be considered a confirmed reservoir if economic use were presently being made of its waters.

Potential for Discovery: 0ther than in the Madison formation, there is limited potential for discovery. 
SOUTH DAKOTA

\section{Introduction}

In terms of geothermal geology, South Dakota has two main features of interest: the Madison formation aquifer and the Black Hills. The Madison formation occurs at depth throughout western South Dakota (see Figure 43). This formation is composed of Mississippian carbonate rocks which contain a regionally interconnected network of intergranular-, fracture-, and solution-opening porosity. Virtually every properly completed well into the Madison encounters waterflow, which is artesian where surface elevations are 700 meters or less. Recharge to the Madison comes predominantly from the Black Hills, where winter snowmelt and summer rains enter the highly porous rocks at their outcrop around the Black Hills uplift. This meteoric water flows through the Madison system to depths of more than a thousand meters. The water is heated mostly from the normal geothermal gradient, but an area of hotter water occurs in the southeast where there may be a separate heat source. Wells into the Madison produce water varying in temperature up to $80^{\circ} \mathrm{C}$. Water quality is generally good, but deteriorates in northwestern South Dakota on the edges of the Williston Basin, where evaporite beds occur in the upper part of the Madison.

At the present time artesian Madison hydrothermal waters are being used for space heating at Midland and Philip, South Dakota.

\section{High-Temperature Resources}

Confirmed Reservoirs: None.

Prospects: None. 


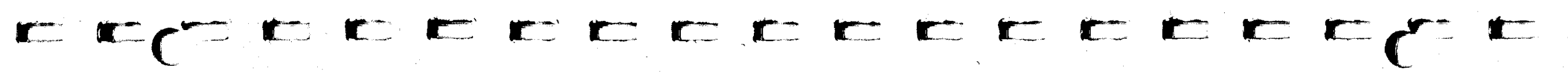

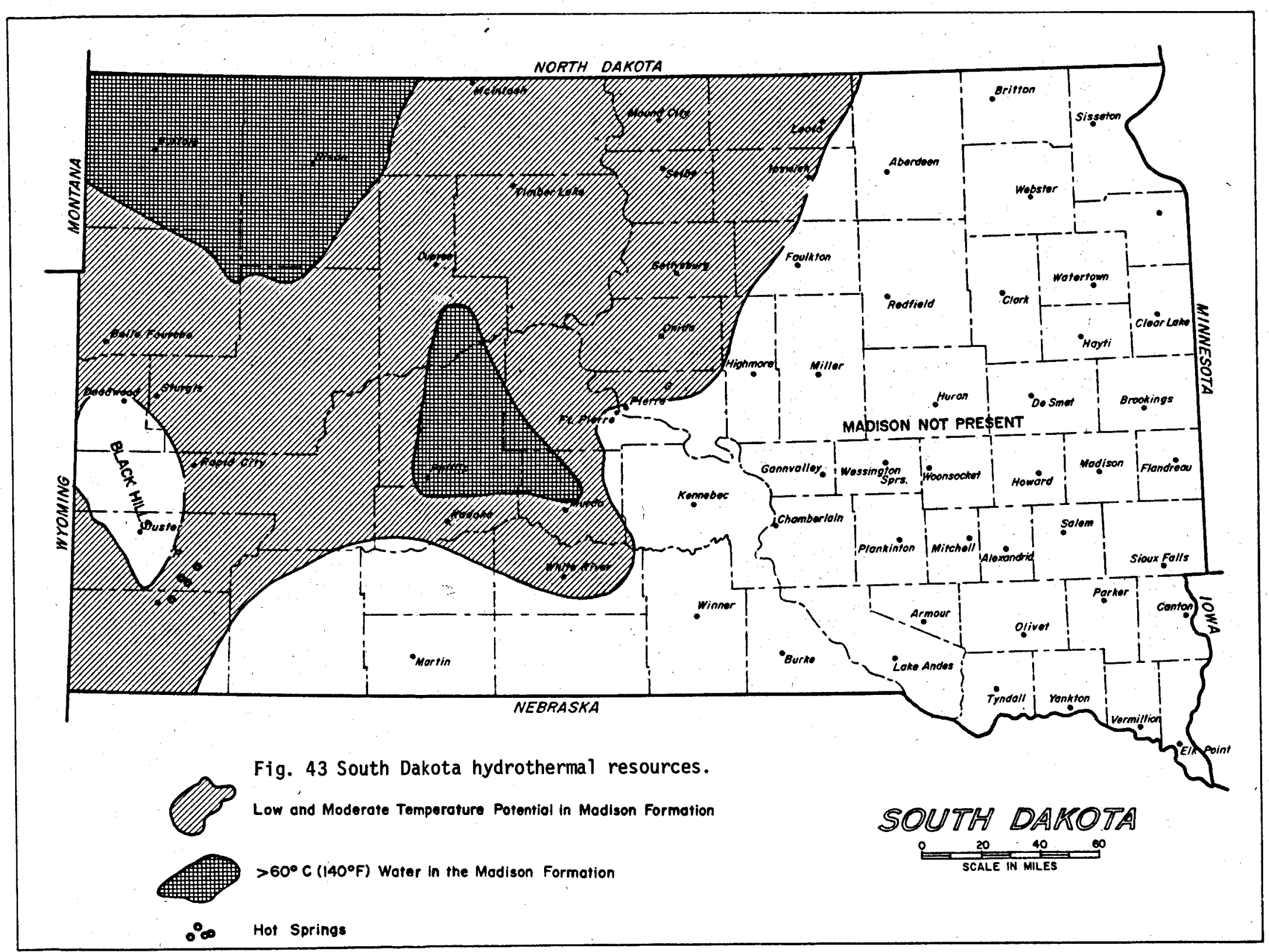


Potential for Discovery: Small.

Low- and Moderate-Temperature Resources (see Figure 43)

Confirmed Reservoirs: The Madison aquifer appears to be capable of producing heated waters wherever it is encountered, and must be considered a confirmed reservoir of great size.

Prospects: None other than the Madison formation.

Potential for Discovery: 0ther zones of porosity, both above and below the Madison formation, have been located during petroleum-well drilling. It is possible that some production might ultimately come from them, although the Madison is the only known aquifer with a regionally interconnected recharge system capable of sustained artesian flow. 
$\underline{\text { UTAH }}$

Introduction

Three physiographic provinces occur in Utah; the Basin and Range province, the Colorado Plateau province, and the Middle Rocky Mountains province (see Figure 44). The Basin and Range province is characterized by northward-trending mountain blocks separated by flat valleys filled to depths of a thousand meters or more with unconsolidated alluvial debris. Recent fault scarps, young volcanic rocks, and observed seismic activity indicate that the Basin and Range is now tectonically active, as it has been for the past 20 million years. The Colorado Plateau province is an area of predominantly flat-lying sedimentary rocks, with several rugged mountain ranges cored by laccolithic intrusions about 60 million years old. This area is mostly inactive geologically. The Middle Rocky Mountains province contains folded and faulted sedimentary, intrusive, extrusive, and metamorphic rocks. There is seismic evidence for active faulting in portions of this province, but no young igneous activity has been located.

The transition zones between the Basin and Range province on the one hand, and the Colorado Plateau and Middle Rocky Mountain provinces on the other hand, are hydrothermally important features. The Roosevelt Hot Springs, Cove Fort-Sulphurdale, Thermo, Monroe, and other hydrothermal areas occur along this transition in west-central and southwestern Utah (see Figure 44). In northern Utah numerous warm springs are found along the Wasatch fault zone and along other closely associated fault zones immediately to the west. Westerly trends of intrusion, such as the Beaver-Tushar-Pioche and the Tintic-Deep Creek trends, may exert regiona 1 . control on the location of hydrothermal resources in western Utah. 


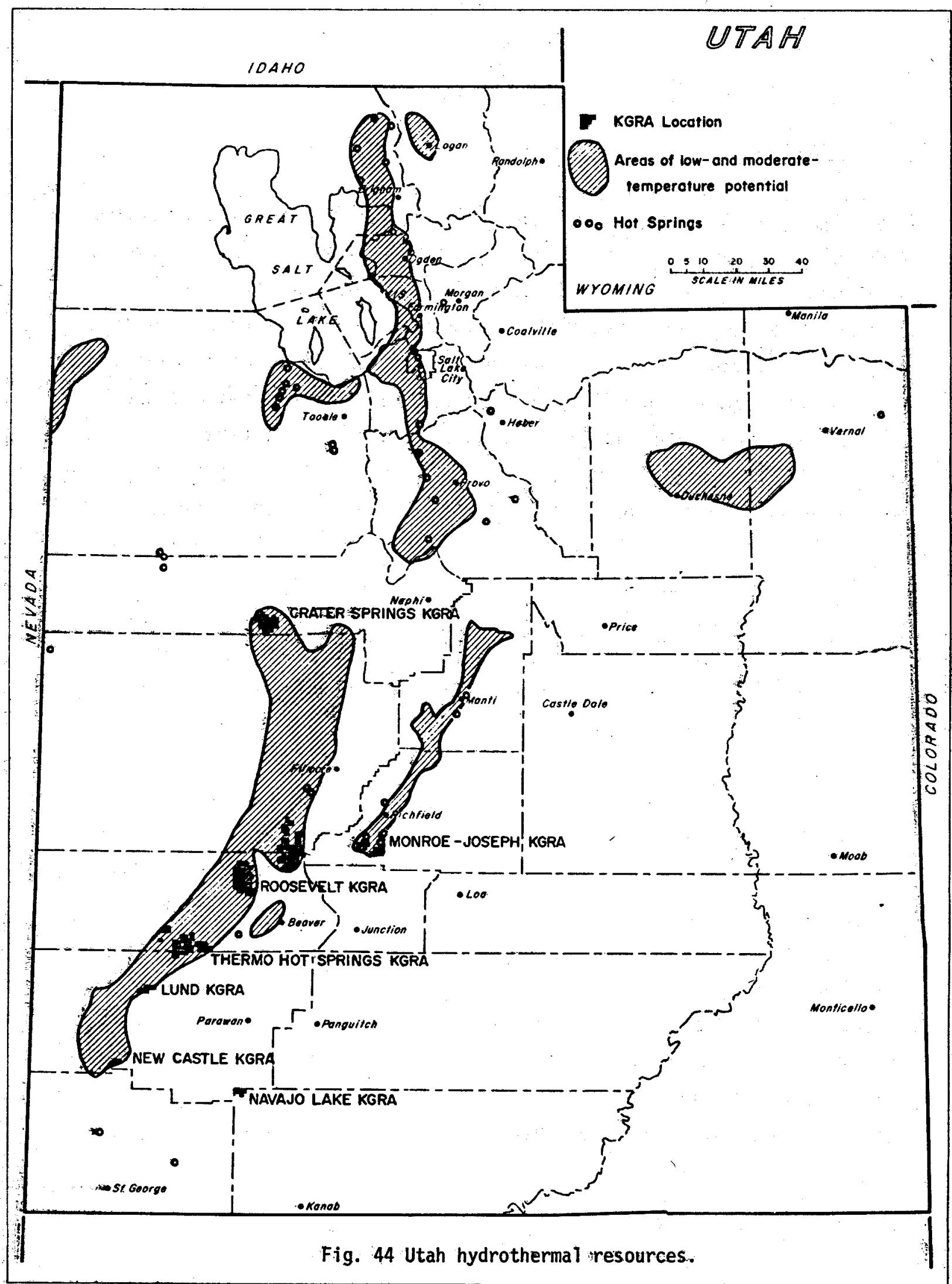


High-Temperature Resources (see Figure 44)

Confirmed Reservoirs: One confirmed water-dominated hydrothermal reservoir occurs in Utah, at the Roosevelt Hot Springs KGRA near Milford. of a total of twelve wells drilled at Roosevelt to date, seven are considered by industry to be producers. The reservoir rocks appear to be highly fractured Tertiary granite. Shut-in water temperatures are about $260^{\circ} \mathrm{C}$ at depths varying from about 300 meters to more than 1500 meters.

Present industry plans call for two 55-MWe plants on line by 1982. The first will be a joint venture among Phillips Petroleum Co. (producer), Rogers Engineering (operator), and Utah Power and Light Co. (distributor). For the second plant, O'Brien Resources (producer), VTN Consolidated (operator), and Utah Power and Light (distributor) will combine their efforts.

Prospects. Two areas in west-centra1 and southwestern Utah are excellent prospects for high-temperature resources suitable for electrical generation. They are the Cove Fort-Sulphurdale KGRA, where Union 0 il Co. is actively exploring with help from the Industry-Coupled program, and the Thermo KGRA, where Republic Geothermal is exploring. Industrial sources claim that a total of seven significant hot spots occur in Millard, Beaver, and Iron counties.

Potential for Discovery: The transition zone between the Basin and Range and the Colorado Plateau provinces offers further potential for discovery. Investigators have recognized a possible trend of 10-millionyear-old or younger plutons with associated extrusive rocks coincident with the Pioche-Beaver-Tushar mineral trend. Very young volcanic rocks which occur near fillmore are currently being investigated by the University of Utah. 
Low- and Moderate-Temperature Resources (see Figure 44)

Confirmed Reservoirs: None.

Prospects: Many prospects for direct heat hydrothermal waters exist in Utah. A total of 41 thermal springs are known in Utah, and a recent compilation of water well temperatures has revealed the existence of several hundred anomalously warm wells. These warm water occurrences are found mainly in the Basin and Range Province along its transition with the Colorado Plateau in the south and the Rocky Mountains in the north. Preliminary investigations of a number of hot springs sites from the Utah-Idaho border to southern Utah Valley have begun. These resources have potential space heating and, in some cases, process water applications. At Monroe, a Program Opportunity Notice (PON) project is currently underway. It is designed to test a warm spring system for warmer water at depth, to be used for space heating. However, warm water can be found in other regions of the state, such as water from oil wells near Vernal and brine from wells near Wendover. Little or no testing of these potential areas has yet begun.

Potential for Discovery. There is good potential for discovering water suitable for space heating or for heat-pump applications along the Wasatch Fault zone, where the great majority of the state's population lies. Other major potential lies in the Basin and Range, in most cases in sparsely populated areas. 


\section{WYOMING}

Introduction

Yellowstone National Park contains the world's largest concentration of hydrothermal features. Outside the bounds of the national park, however, there are few thermal features, and the state's known hydrothermal resources are mostly of low temperature. The heat-flow anomaly associated with recent volcanic activity within Yellowstone National Park appears to terminate abruptly outside the park to the east.

Exploration for uranium, $0 i 1$, and gas has revealed slightly abnormal thermal gradients over much of the state, and a widespread potential for low-temperature utilization exists. The Madison aquifer is present over much of eastern Wyoming and is known to contain moderate-temperature fluids in places. Systematic information, however, has not been compiled, and so the potentially large Madison resource is not shown on the resource map (see Figure 45).

\section{High-Temperature Resources}

Confirmed Reservoirs. None.

Prospects. None

Potential for Discovery. The geochemistry of the Huckelberry Hot Springs and the Auburn Hot Springs south of Yellowstone indicates high reservoir temperatures, but capacity may be limited.

\section{Low- and Moderate-Temperature Resources}

Confirmed Reservoirs. Thermopolis, Wyoming, is a well-known, highvolume warm spring that has a long history of recreational usage. The thermal waters are presently being considered for expanded direct-heat applications. 


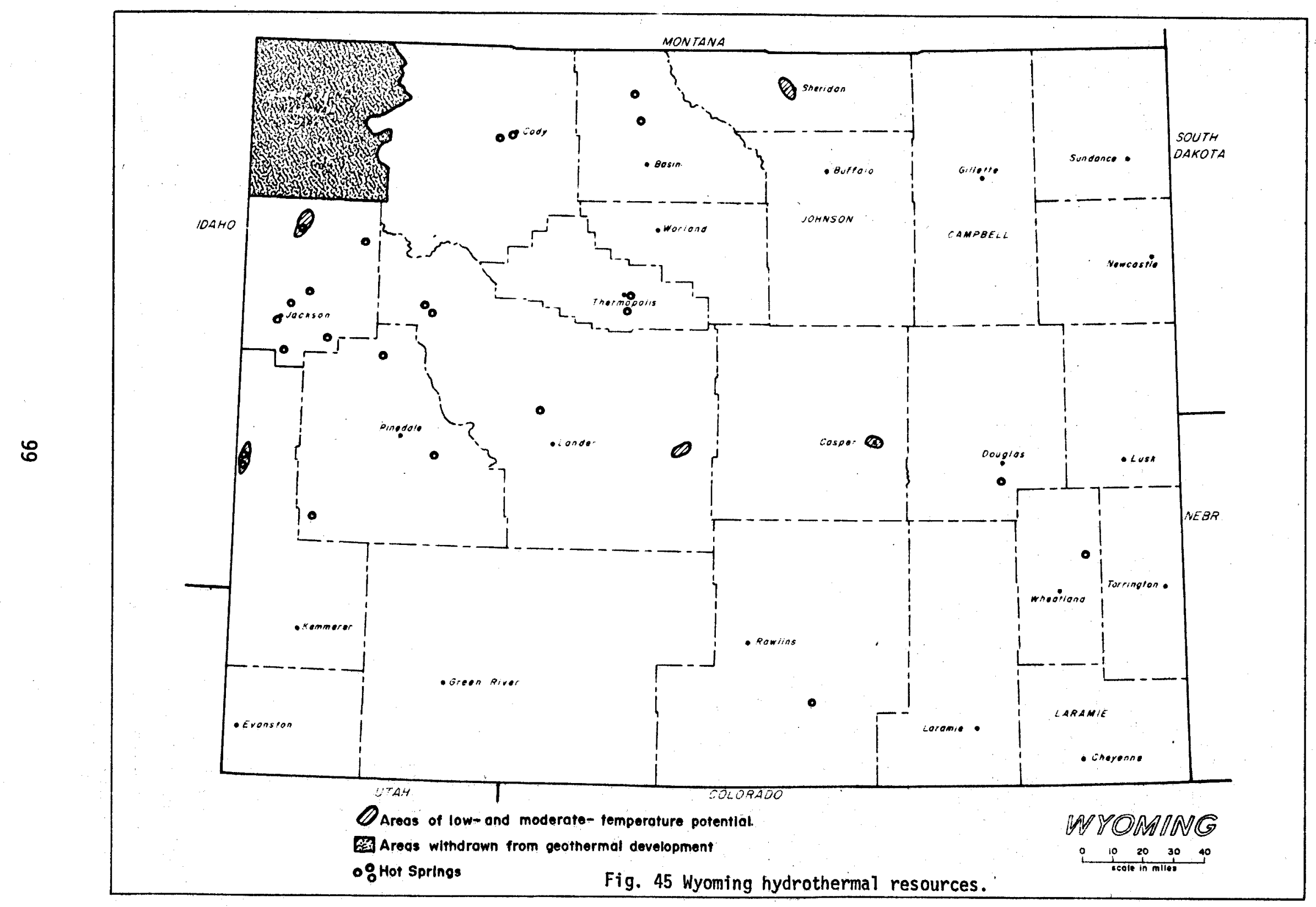




\section{Prospects. None.}

Potential for Discovery. Numerous intermediate and deep wells drilled into the Madison acquifer have encountered abnormal gradients and low- to moderate-temperature fluids. Areas of particular interest include Casper and Sheridan. Some limited use is now being made of the near-boiling water for "water-flood" secondary oil-recovery operations. 


\section{REFERENCES}

1- W. R. Hahman, Sr., C. Stome, J. C. Witcher, Geothermal Energy Resources of Arizona, Geotherma 1 Map No. 1. Bureau of Geology and mineral Technology, Univ. of Arizona. (1978)

2- C. A. Swanberg, P. Morgan, C. H. Stoyer, J. C. Witcher, An Appraisal study of the Geothermal Resources of Arizona and Adjacent Areas in New Mexico and Utah and their value for Desalination and other uses. New Mexico Energy Insti tute, Los Cruces, New Mexico. (1977)

3- M. Reiter, C. L. Edwards H. Hartman, C. Weidman, Terrestrial Heat Flow Along the Rio Grande Rift, New Mexico and Southern Colorado. GSA bulletin vol. 86, pp. 817-818. (1975)

4- M. Reiter, C. Shearer, C. L. Edwards, Geothermal Anomalies Along the Rio Grande Rift in New Mexico, Geology, vol. 6, pp. 85-88. (1978)

5- W. J. Stone, N. H. Mize11, Geothermal Resources of New Mexico: a survey of work to date. New Mexico Bureau of Mines and Mineral Resources open file report $73,117 \mathrm{pp}$. (1977)

6- W. K. Summers, A Preliminary Report on New Mexico Geothermal Energy Resources, New Mexico Bureau of Mexico and Mineral Resources Circular 80, $41 \mathrm{pp}$. (1965)

7- W. K. Summers, Geothermal Resources of New Mexico, New Mexico Bureau of Mines and Mineral Resources. Resources Map 1. (1972)

8- C. A. Swanberg, Personal Communication. (1978) 


\section{v. STATE BY STATE COMMERCIALIZATION PLAN}

Commercialization profiles will be developed for each state. Each state commercialization profile will contain resource-development forecasts, estimating both power-on-line and the time frame in which it occurs; type of development anticipated; resource quality required and anticipated; and barriers impeding successful commercialization. The profiles will be developed through prospect commercialization scenarios which will hypothesize prospect commercialization and analyze industry, state, local and federal requirements through an iterative collective planning process with all of the involved participants. Department of Energy commercialization initiatives will be evaluated for effectiveness during this analysis and successful initiatives will be maintained. Unsuccessful initiatives will be terminated and new initiatives will be developed when inroads to barrier mitigation can be identified.

The state by state profiles are being prepared by the state commercialization planning contractors and are not currently available.

The individual prospect commercialization scenarios which follow provide examples of when and how hydrothermal resources will be brought on-line, and serve to illustrate the planning activity in progress. Examples include the development of a high temperature resource for electric power generation at Cove Fort, Utah (see Figure 46-48); the application of new technology for electric generation with a moderate temperature resource at Stillwater/Soda Lake, Nevada (see Figure 49-51); the development of the moderate temperature resource in the Vale-Weiser-Ontario area (Oregon and Idaho) for direct applications (see Figure 52-53); and the progressive spread of these applications across the Snake River Plain (see Figure 54-56).

A cooperative effort between the private sector and the local, state and federal governments is needed for development to proceed in a timely 
manner. The scenarios indicate the required federal, state and local activities which must take place for development to proceed. In addition, the Department of Energy initiatives which are designed to encourage the involvement of the private sector during the early stages of hydrothermal commercialization when the risk is comparatively high, are depicted in the prospect commercialization scenarios. Descriptions of the Department of Energy's initiatives can be found in Section VI of this plan.

The commercialization scenarios presented herein have been developed with the assumption that the hydrothermal energy resource will enjoy equitable tax treatment in the near future. 


\section{COVE FORT PROSPECT COMMERCIALIZATION SCENARIO}

Cove Fort is a known geothermal resource area (KGRA) in the southwestern quadrant of Utah. There are no surface springs at Cove Fort, but the surface is characterized by active gas seeps and thermally altered areas.

Drilling began at Cove Fort in the summer of 1976. Union $0 i 1$ drilled an 1100 foot well. This well was plagued with drilling difficulties and eventually caved in. There was no further drilling activity until late in 1977 when Union 0il, utilizing a cost sharing program with the Department of Energy (Industry-Coupled Program), drilled a second well deeper than the first. This well was also very difficult to drill and was not a commercial producer; however, evidence of high temperature fluid was found and a third well is currently being drilled with a fourth well planned. The second, third and fourth wells are being drilled as a part of the Department of Energy's Industry-Coupled Program.

Several miles farther north, Hunt Energy Corporation is drilling an exploratory well on private lands. A transmission line will be required for a unit at the Hunt site. It is assumed that the $46 \mathrm{kV}$ and $138 \mathrm{kV}$ lines near the Union wells have the capacity to handle the first unit at that site.

For purposes of this prospect commercialization scenario, it is assumed that drilling in both areas will lead to production of a commercial high temperature resource. 


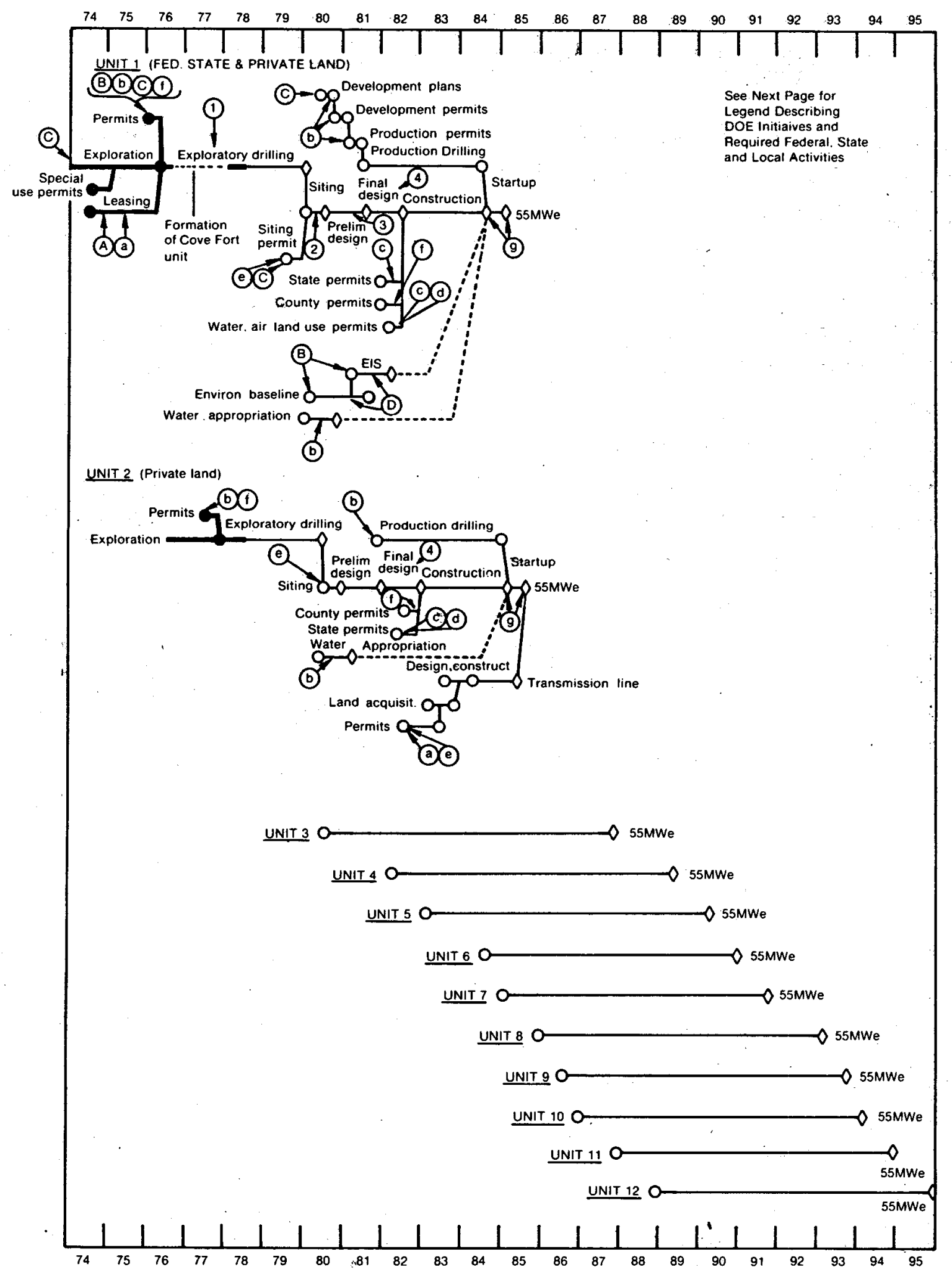

Fig. 46 Cove Fort high temperature electric prospect commercialization scenario. 


\section{DOE Initiatives}

(1) DOE/Industry cost sharing for drilling exploratory wells (Industry Coupled Program)

(2) Economic study funded under DOE Program Research and Development Announcement (PRDA)

(3) DOE/Industry cost sharing of preliminary design by means of the Program Opportunity Notice (PON)

(4) Loan guaranties for drilling and/or for construction

\section{Required Federal Activities}

(A) Leasing of federal lands by Bureau of Land Management

(B) Surface management of national forest lands by Forest Service including environmental assessment and concurrence in leasing and permitting

(C) Permitting for surface exploration, drilling and plant siting on federal lands by the Conservation Division of the U.S. Geological Survey

(D) EIS/EIA wildlife evaluation by the Fish And Wildlife Service, Department of Interior

(E) Certify air discharge permit, issue water discharge and solid waste disposal permits, review of EIS by Environmental Protection Agency

\section{Required State and Local Activities}

(a) Lease of state lands and special use permits for surface disturbance by the Division of State Lands

(b) Well permits, reservoir test approval, appropriation of water by the Division of Water Rights

(C) Construction plan review and permit, discharge permit certification, waste disposal permit approval by the Bureau of Water Quality

(d) Construction plan review and approval and discharge permit by the Bureau of Air Quality

(e) Land zoning by the County Planning Commission

(f) Business license by the County clerk

(9) Building inspection and health code enforcement by the County Commission

Fig. 47 Legend for Cove Fort scenario. 


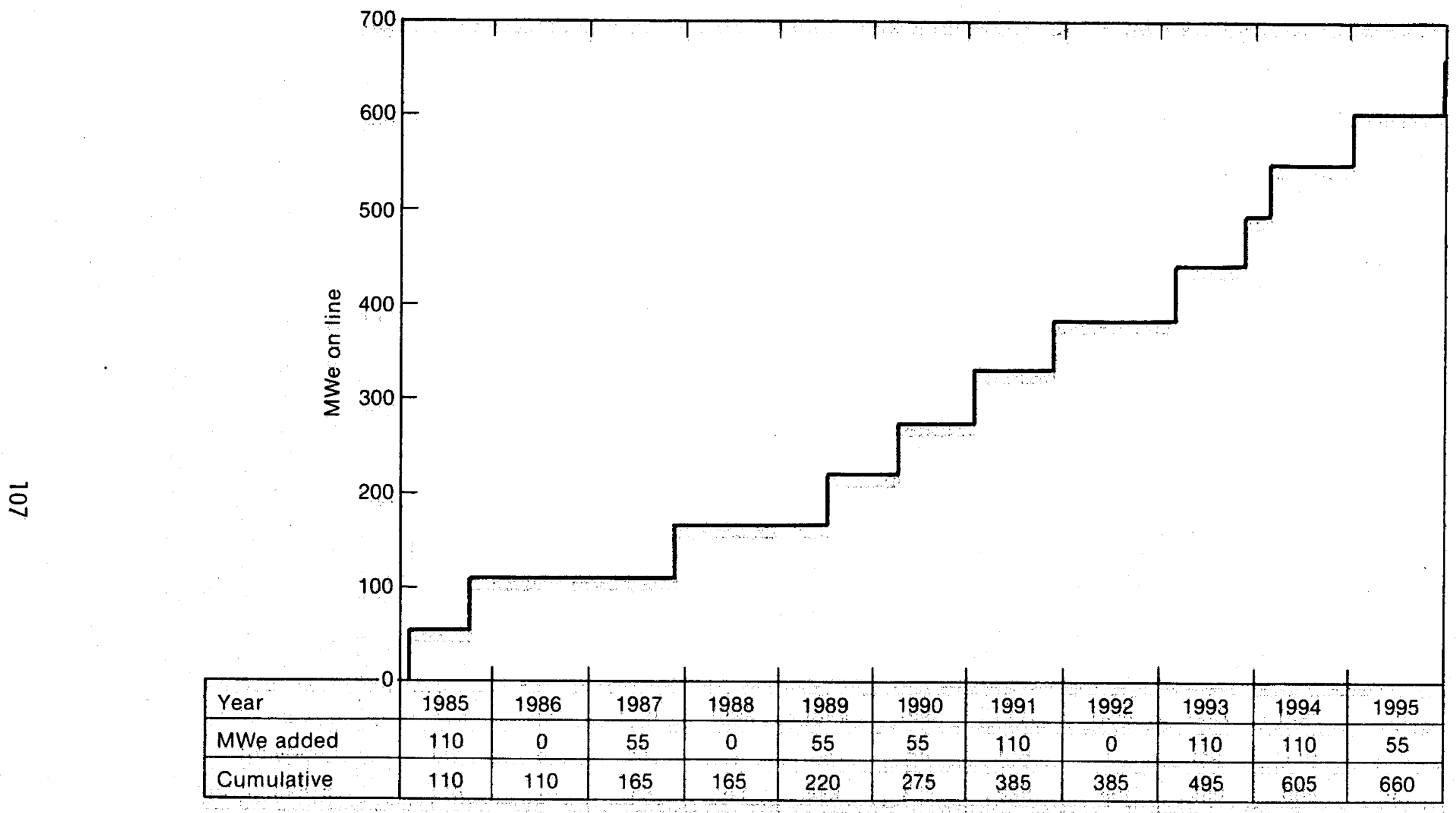

Fig. 48 Cove Fort projected power on line. 
The Stillwater/Soda Lake KGRA is located about 60 miles east of Reno, Nevada. Exploratory wells indicate that a $165^{\circ} \mathrm{C}$ hydrothermal resource exists at approximately 7500 feet.

Design of the first commercial electric power unit for this site is not expected until the feasibility of utilizing binary technology for moderate temperature resources is demonstrated by Raft River Loop 1. By the time design starts for the second unit, results from Raft River Loop 2 should be available. This loop will demonstrate the economic feasibility of utilizing advanced binary technology for moderate temperature resources. 


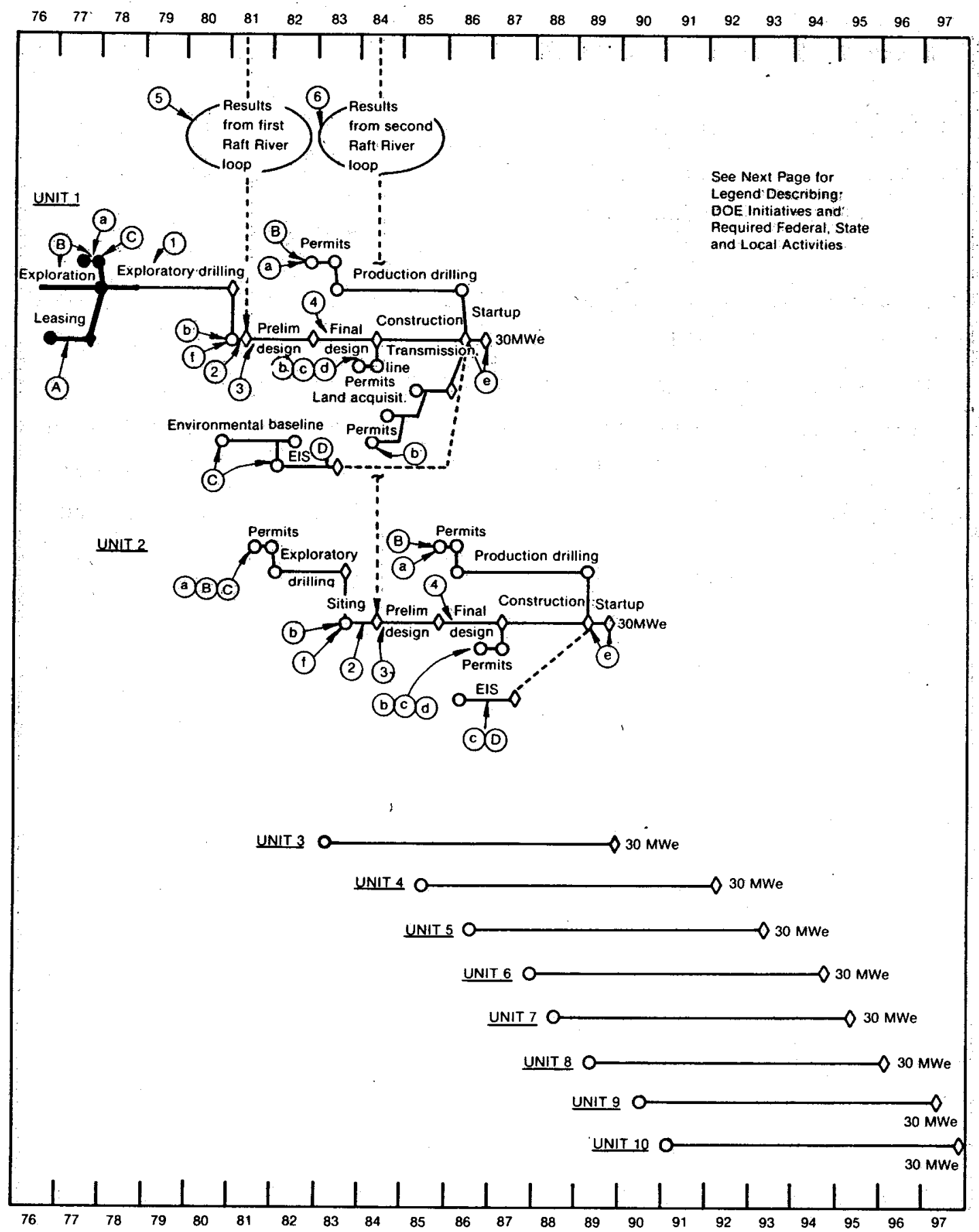

Fig. 49 Stillwater/Soda Lake moderate temperature electric prospect commercialization scenario. 


\section{DOE Initiatives}

(1) DOE/Industry cost sharing for drilling exploratory wells (industry coupled program)

(2) Economic evaluation funded under DOE Program Research and Development Announcement (PRDA)

(3) DOE/Industry cost sharing of preliminary design by means of the Program Opportunity Notice (PON)

(4) Loan guaranties for drilling and/or for construction

(5)Demonstrate feasibility of moderate temperature binary technology

6) Demonstrate economic feasibility of using advanced binary technology for moderate temperature resources

\section{Reguired Federal Activities}

(A) Leasing of Federal Lands by Bureau of Land Management

(B) Permitting for surface exploration, drilling and plant siting on Federal Lands by the Conservation Division of the U.S. Geological Survey

(C)EIS/EIA wildlife evaluation by the Fish And Wildlife Service, Department of Interior

(D) Certify air discharge permit, issue water discharge and solid waste disposal permits, review of EIS by Environmental Protection Agency

\section{Required State and Local Activities}

(a) Well permits, reservoir test approval and appropriation of water by the Nevada State Engineer

(b) Siting authority, construction plan review and permits, and discharge permits by the Nevada Public Service Commission.

(C)Land zoning by the County Clerk

(d)Land zoning by the County Planning Commission

(e) Building inspection and health code enforcement by the County Commission

Fig. 50 Legend for Stillwater/Soda Lake scenario. 


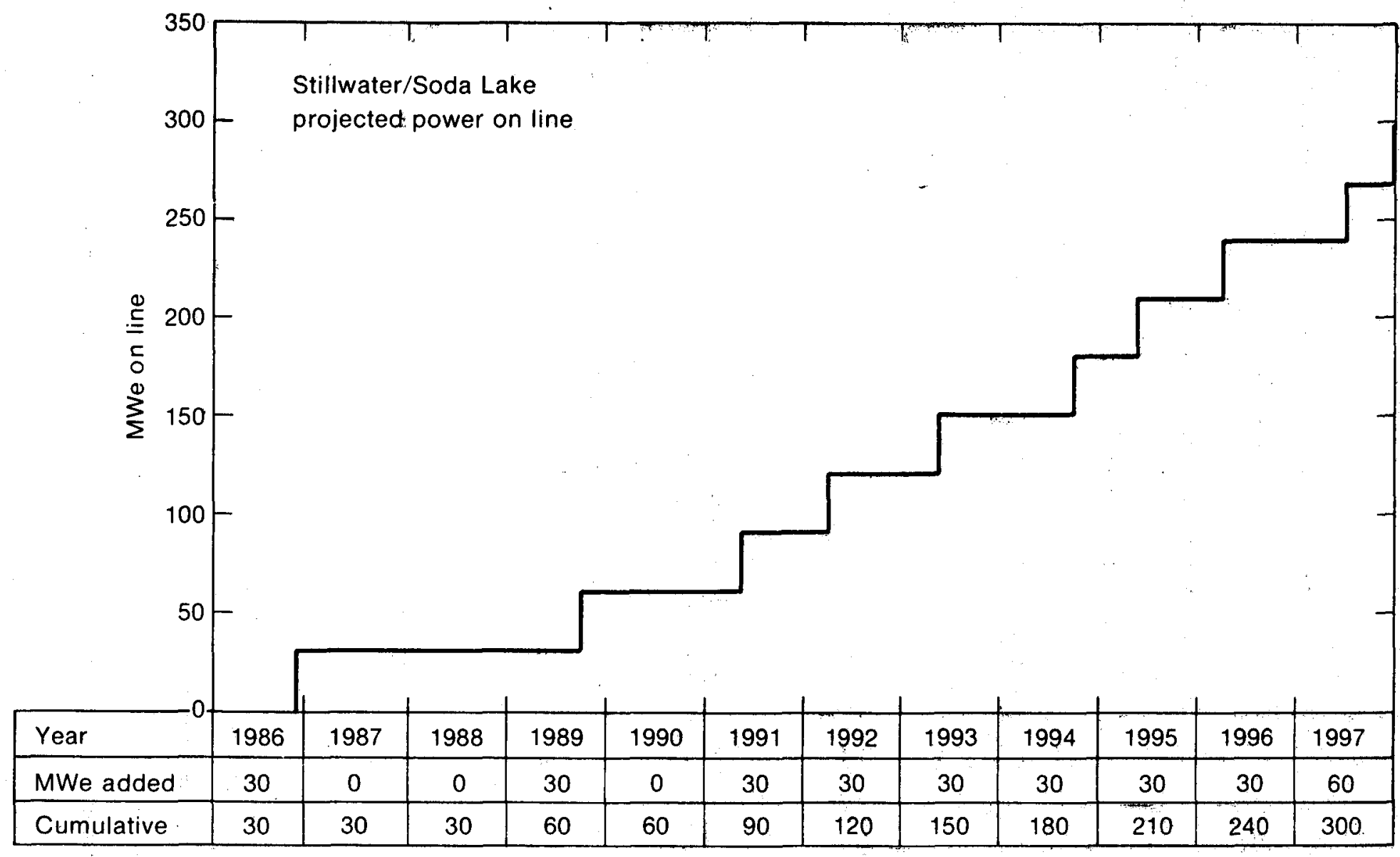

Fig. 51 Stillwater/Soda Lake projected power on line. 


\section{DIRECT APPLICATIONS PROSPECT COMMERCIALIZATION SCENARIO}

The commercialization scenario for direct applications development is best illustrated using both an application and resource spreadout technique. Most direct application units are relatively small when compared to the step by step development of a field for electric power, but initially an exponential type of growth can be postulated for both the types of applicaiton and the number of resources. The initial commercialization pattern depicted herein was initiated by a Program Research and Development Announcement (PRDA) engineering and economic analysis which in turn was followed by the submittal and acceptance of a field demonstration Program opportunity Notice (PON) cost sharing proposal. Following the initial success of reservoir confirmation and proof of operating principle further development is anticipated in two directions, other applications will be initiated within the resource area of the original field, as shown for the Vale-Weiser-Ontario prospect, and competing processors will either develop the resource at existing facility sites, where resources and sites coexist, or tend to move to known resources to develop new facilities, as shown for the Snake River Plain prospect.

This scenario is illustrative of the anticipated two-pronged commercialization process. 


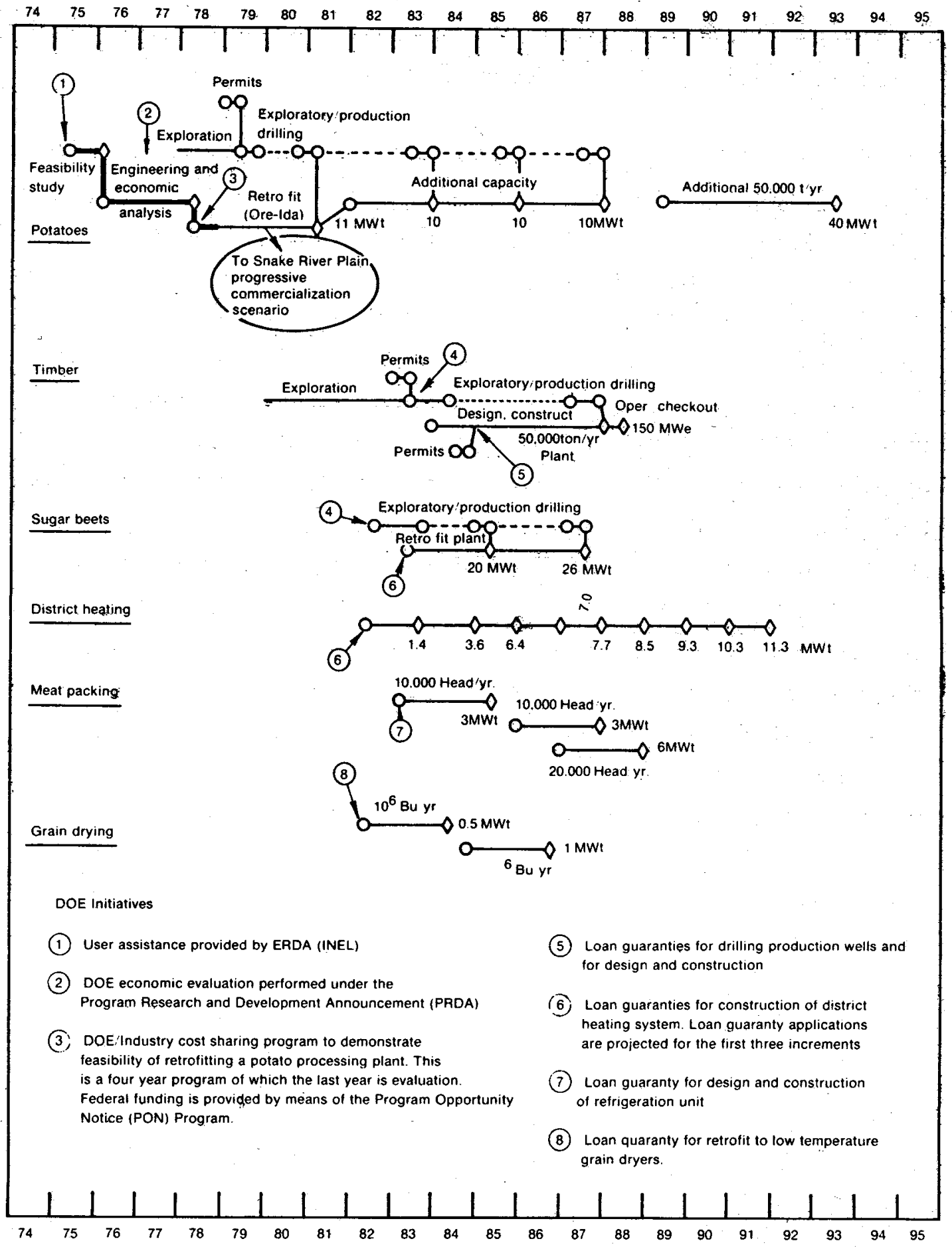

Fig. 52 Vale-Weiser-Ontario prospect commercialization scenario for direct applications. 


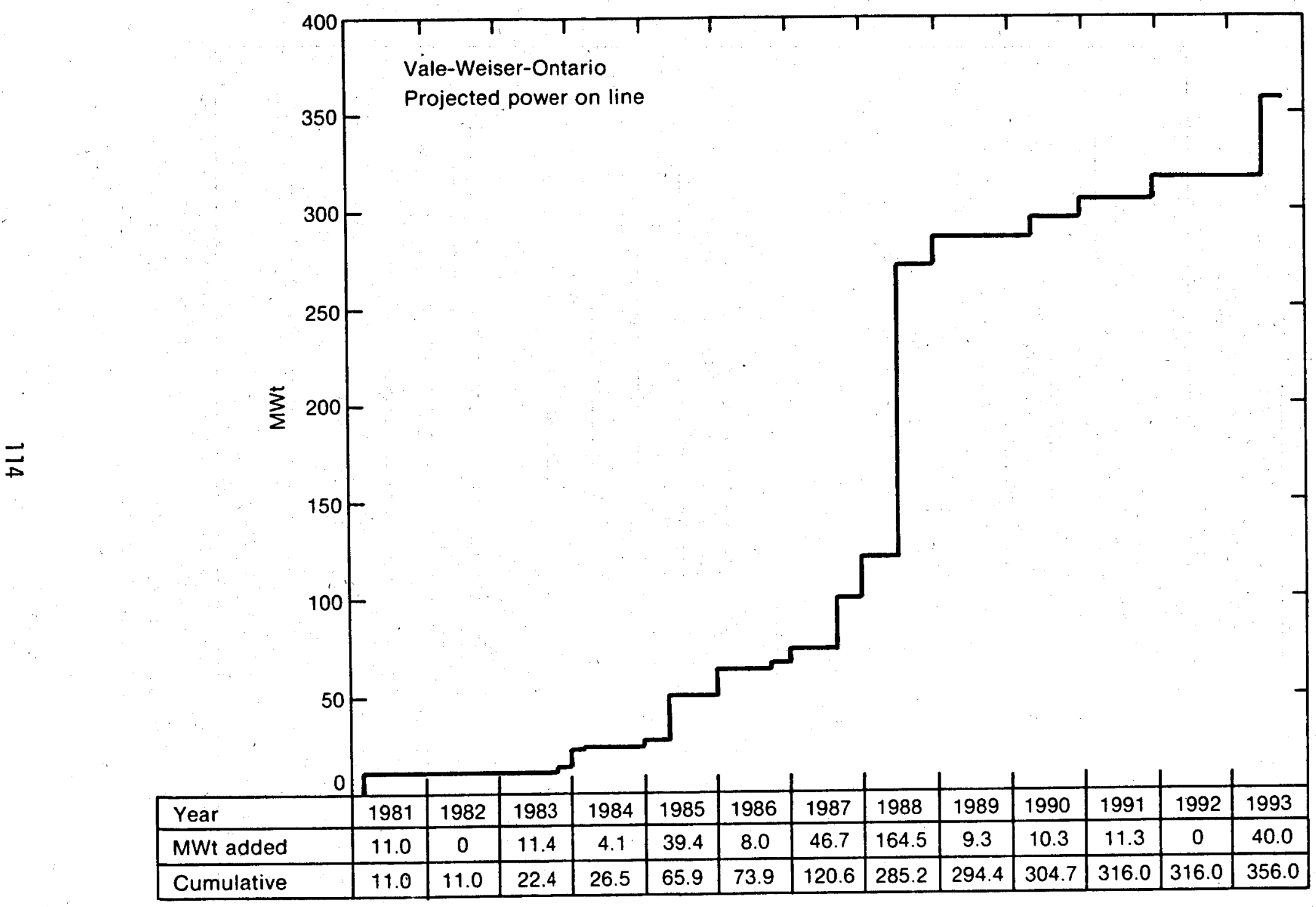

Fig. 53 Vale-Weiser-Ontario projected power-on-line. 


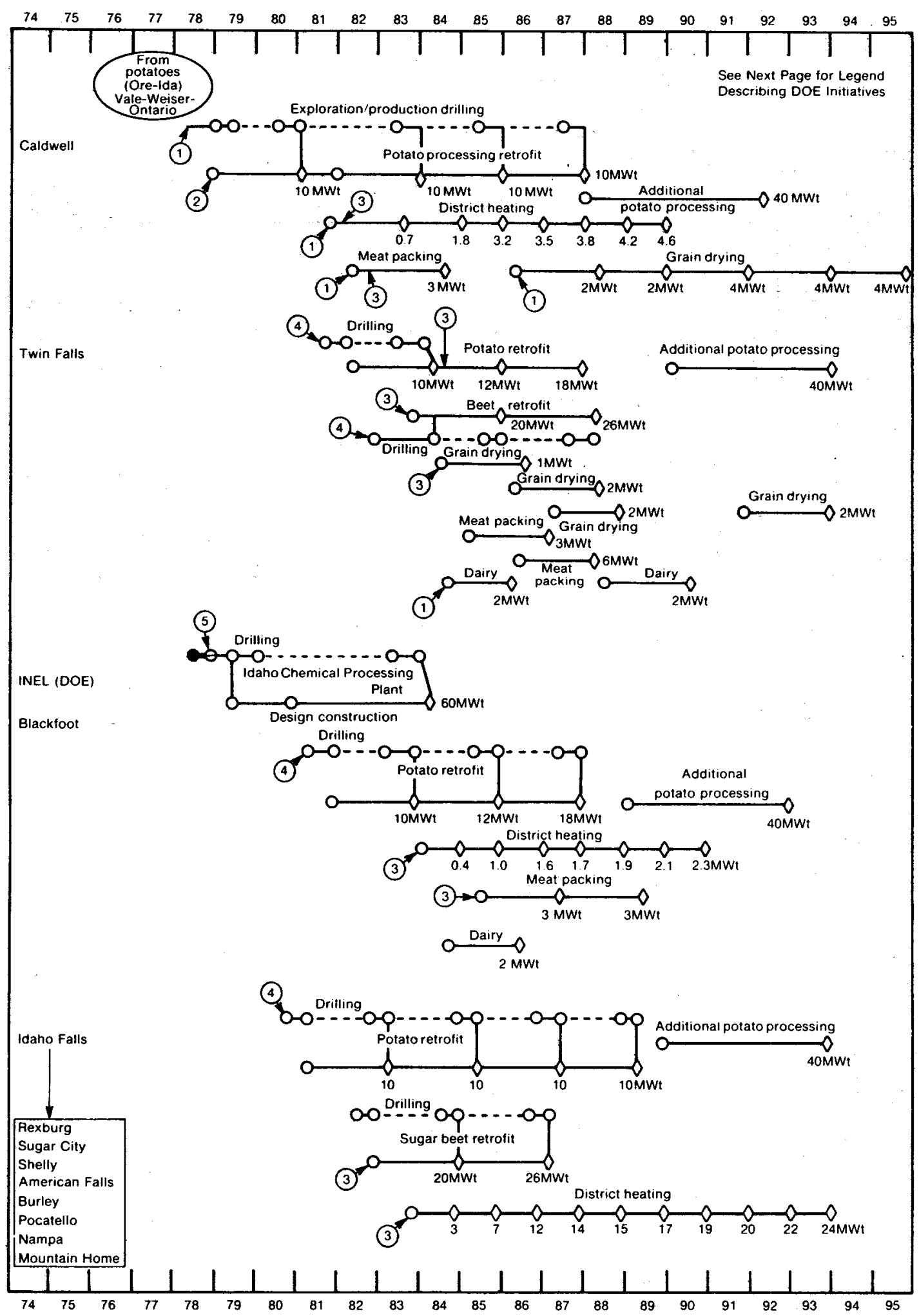

Fig. 54 Snake River Plain commercialization scenario for direct applications. 
DOE INITIATIVES

(1) User assistance, provided by DOE (INEL) to determine feasibility of using resource for proposed application

(2) DOE/Industry cost sharing provided by the Program Opportunity Notice (PON) Program

(3) Loan guaranty for construction

(4) DOE/Industry cost sharing or exploratory wells provided by the state coupled program

(5) As part of the resource assessment for the Snake River Plain, a joint DOE/USGS deep well will be drilled starting in August, 1978.

Fig. 55 Legend for Snake River Plain scenario. 


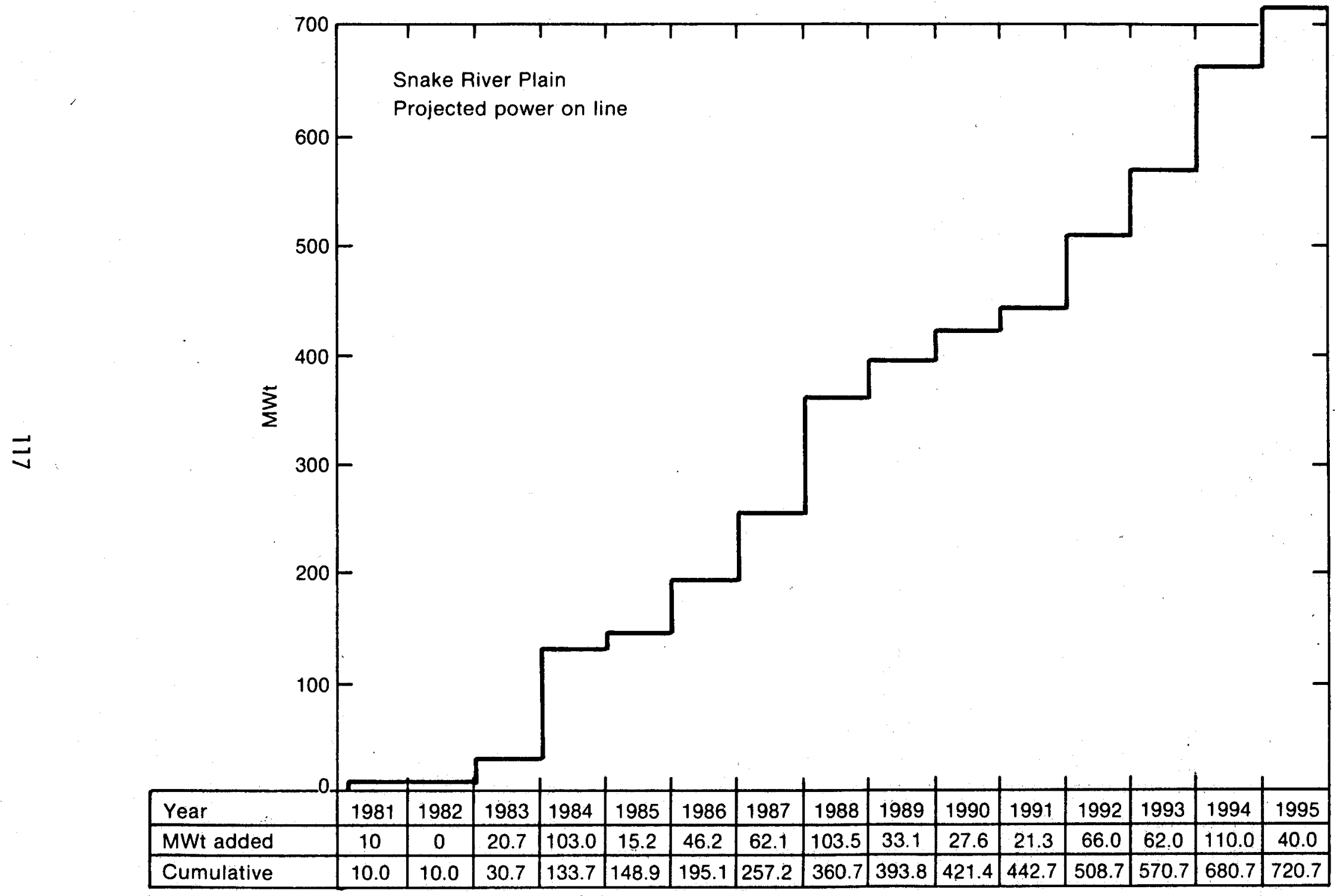

Fig. 56 Snake River Plain projected power-on-line. 


\section{DOE WORK DESCRIPTION}

The development of hydrothermal resources in the Rocky Mountain Basin and Range Region is made up of six major tasks. These are Regional Planning, Resource Definition, Technology Applications - Electric, Technology Applications - Direct Heat, Environmental Control, and the Raft River (Idaho) Facility. Figure 57 shows the tasks in outline form. The purpose of this work is to stimulate the development of hydrothermal resources in the region in an economic, reliable, operationally safe and environmentally acceptable manner, to encourage cooperation among all concerned parties, to identify and describe hydrothermal potential, to identify and attempt to resolve constraints, and to provide a framework wherein all facets of development can work together to speed up the utilization of hydrothermal energy. The relative level of activity required is illustrated in Figure 58. Following is a discussion of the six major tasks.

\section{REGIONAL PLANNING}

Regional planning includes program coordination, policy development, and state commercialization planning and outreach. The objectives of this effort are to:

- Provide for program development, coordination, reporting, information dissemination, schedule and fiscal, and planning, and work change control;

- Identify and resolve regulatory, legal, economic, and other institutional restraints that impede use of electric and direct heat hydrothermal energy;

- Prepare state hydrothermal commercialization plans (scenarios). and perform outreach with potential users.

The planning process is illustrated in Figure 59. 


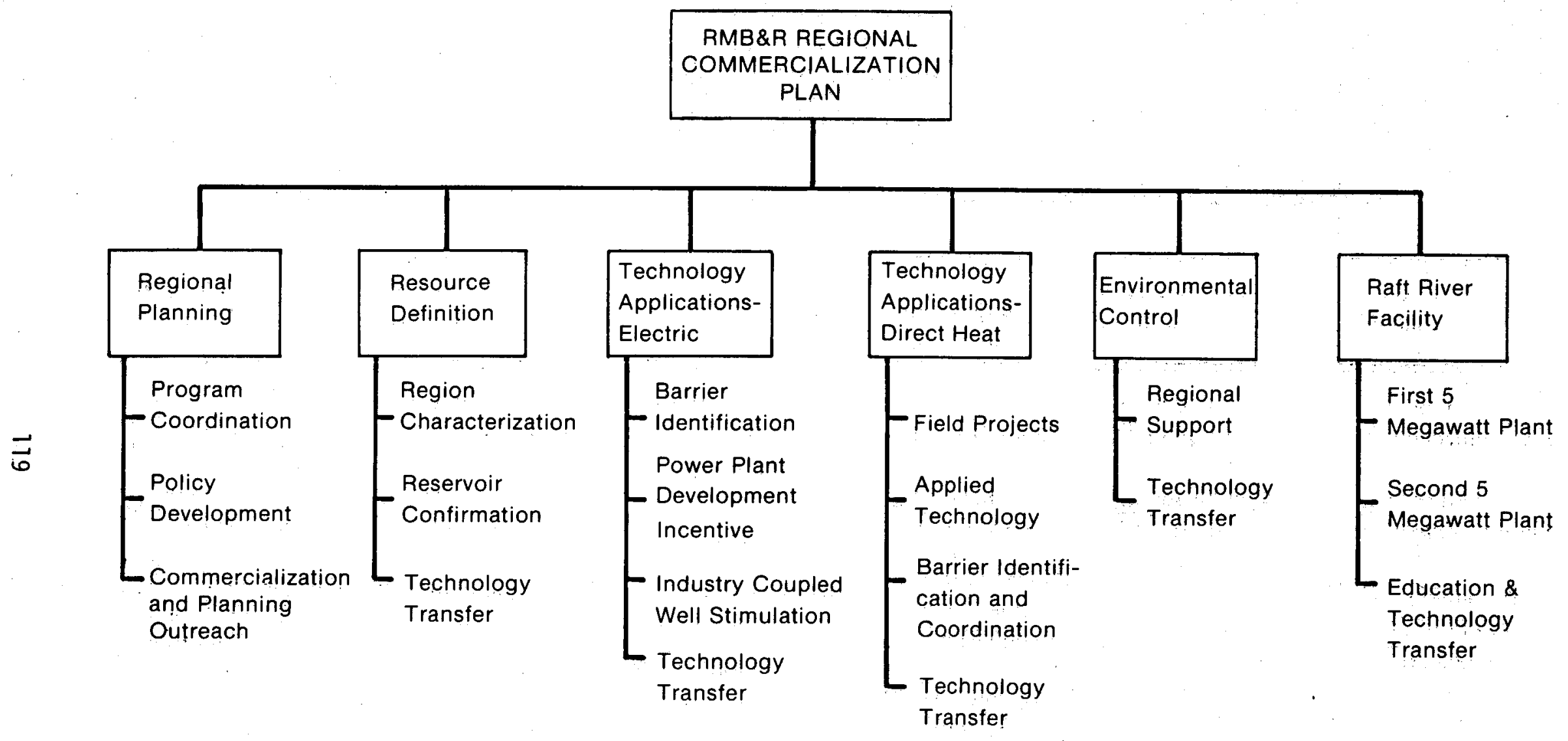

Fig 57 DOE program outline. 


\section{Program Coordination}

The regional coordination effort ties together all hydrothermal work funded for the Rocky Mountain Basin and Range Region development activities, which provides a systematic plan for achieving regional energy goals. The planning process will identify the prime targets for concentrating federal resources, to accelerate the commercial acceptance and use of hydrothermal energy. Effective planning will also eliminate those initiatives that have little potential for producing power on line.

The total planning and coordination effort requires direct involvement of the regional planning staff, as well as the task managers responsible for implementation, execution, and control of work. The process will evolve as participants obtain experience and as technology is transferred.

Regional program coordination involves Department of Energy program development, schedule and fiscal planning, change control, and general coordination of Department of Energy activities within the region.

\section{Policy Development}

The goal of policy development work is to identify and resolve regulatory, legal, economic, and other institutional issues that impede the implementation of both electric and direct-use applications of hydrothermal energy. Additionally, analys is will be made to define the consistency of the regulations and requirements of federal, state, and local agencies. Areas of duplication will be identified and recommendations made to appropriate federal agencies through the Interagency Geothermal coordinating Council (IAGCC) and to the states through the National Conference of State Legislatures (NCSL), or other appropriate channels, to alleviate unnecessary duplication.

The principal contributors and their main functions are: 
1. The geothermal policy project office of the National Conference of State Legislatures, working directly with the appropriate energy and natural-resource subcommittees of the state legislatures, conducting policy reviews and recommending legislation to expedite development.

2. State commercialization planning contractors collect data and analyzing the impacts of public policies.

3. The Idaho Operations Office of the Department of Energy, with EG\&G Idaho, Inc., performing the policy development function, which involves:

- coordinating the efforts of the above;

- creating autreach programs by establishing regional policy-implementation workshops and other means to encourage development;

- providing a regional perspective and analysis to those conducting policy research at the national level; and

- performing liaison functions to insure coordination among federal groups.

The Policy Development Work element will consist of analysis and outreach activities. The NCSL program will focus on a wide range of issues critical to this work element, such as resource characterization, resource access, development and environmental regulations, as well as financial and marketing incentives. To the extent requested by the Department of Energy's Division of Geothermal Energy (DOE/DGE), these state analyses will be extended or amplified to provide a regional perspective to policy activities conducted at the national level. Other areas of policy analys is fall beyond the scope of the NCSL program and will be addressed as requested by DOE/DGE. Such areas may inclue federal Energy Regulatory Commission regulations, federal environmental requirements, and federal designation of known Geothermal Resource Areas (KGRAs). 
The outreach dimension of this activity will focus initially on the convening of workshops, primarily by the NCSL, which will include state legislators, geothermal regulators, energy and environmental officials, and state land and water administrators. The purpose of these workshops will be to assess the impact of state statutes and regulations on the course of geothermal energy development and, hopefully, to draft enabling legislation that would encourage and hasten development opportunities in the region. The initial NCSL workshop activity will be concentrated in the states of Utah and New Mexico, and will gradually expand to other states of the region.

A number of liaison activities are essential to a successful policy development program. Regular and frequent consultations will be required with policy analysts in DOE/DGE to provide regional perspectives to their activities. The NCSL program will have regional technical program support from the University of Utah, the University of Utah Research Institute, EG\&G Idaho, Inc, and the state profile development contractors, as well as technical experts from the private sector.

Procedural guidelines will be developed for each state through some of the activities described above, setting forth the process that prospective developers are required to follow for permits and leases, as well as identifying those agencies of state government that must be contacted in the development process.

\section{State Commercialization Planning and Outreach}

This activity, formerly identified in the Department of Energy's Division of Geothermal Energy's program as "operations research," has two primary objectives. The first is the development of both site-specific (where appropriate) and aggregate state hydrothermal-use profiles. These profiles will project (to year 2020) on-line hydrothermal project possibilities and analyze the sensitivity of these projections to various levels of government stimulative programs, to the probable effects of other public policies, and to changing economic and technical conditions. The emphasis in commercialization planning will be on use potential, rather than compilation of resource data. For the latter, state contractors will 
rely on the resource definition assessment programs. Potential user groups, industry sectors, as well as specific enterprises and resource developers, will be identified.

The state commercialization planning process will include, but not be limited to, these activities:

- User and resource data acquisition: costs, revenues, energy supply and demand patterns, capital availability

- Regional energy forecasting

- Market penetration analysis

- Energy/water interface

- Model simulation: calibration of electric and direct-application

- economic models

- Economic issues impact

- Impact of policy options

- Data base implementation and maintenance

Since the state commercialization planning is user-oriented, it is natural to expect that state teams will have a high degree of interaction with resource developers, commerce and industry groups, state governments, as well as individuals and business. Through this interaction and outreach, the hope is to achieve a heightened public perception of hydrothermal development possibilities. A program of information dissemination will be conducted for potential commercial, industrial, and residential project developers. This aspect of the program will also be responsive to particular state requirements (with the NCSL program) for information concerning the technical, economic, and institutional deterrents to hydrothermal commercialization. The outreach activity will include a limfted user-assistance program to potential project developers in each of the states, to answer basic questions about resource development and utilization, and to assist in locating hydrothermal engineering expertise from the private sector. The outreach activities will be coordinated with other federal and state technology transfer programs. 
Structurally, the state commercialization planning and outreach program will be conducted via subcontracts with each of the states desiring to participate. Much of the coordination responsibility, energy forecasting, market penetration, and sensitivity analyses will be carried out by the New Mexico Energy Institute and private consultants as appropriate. 


\section{RESOURCE DEFINITION}

Resource definition includes the geoscience and engineering aspects of hydrothermal resource characterization, and ranges in scope from reconnaissance to site-specific activities, and to reservoir engineering. Resource definition will be the most heavily funded federal activity within the region, not only because resource uncertainty is the first major barrier to hydrothermal development, but also because of the high cost of reservoir confirmation. The basic tasks are region characterization, reservoir confirmation, and technology transfer. They are discussed below.

\section{Region Characterization}

The Rocky Mountain Basin and Range Region can be divided into subregions on the basis of geologic setting (Figure 36). Although this division is somewhat arbitrary, and in places subregional boundaries cannot be located exactly, the concept of geologic subregions forms an appropriate context in which to structure work plans for developing hydrothermal resources. This is true because each geologic subregion can be expected to contain a particular suite of hydrothermal resource types. A discussion of the geologic subregions as defined for our purposes is given in Appendix A.

Region characterization work includes: characterizing the broadscale geologic setting of each subregion and determining the geologic controls on the occurrence of hydrothermal resources; defining and inventorying known hydrothermal occurrences and high-priority areas that have the greatest hydrothermal potential within each subregion; defining the hydrothermal resource types potentially available within each subregion (even though examples of some of those types may not yet have been discovered), based on generalizations from the geologic setting; characterizing the detailed internal geoscience and engineering systematics of each important hydrothermal resource; and formulating an appraisal of the potential power contribution and economics of the hydrothermal resources in each subregion. 
The Division of Geothermal Energy will fund data collection and compilation and analysis activities within the region. Close coordination will be maintained with the activities of state and other federal agencies, especially the U.S. Geological Survey, which is responsible for geothermal resource assessment in the United States.

\section{Reservoir Confirmation}

One of the most critical barriers to accelerating the development of hydrothermal resources is the lack of adequately tested hydrothermal reservoirs. More public information about hydrothermal resources is needed to facilitate exploration, confirmation, reservoir engineering, and economic analysis.

Confirmation of high-temperature reservoirs for electric power generation and of low- and moderate-temperature reservoirs for direct heat application is seriously needed. In order to achieve the regional near-term electrical power goals, about five reservoirs will have to be brought on line. At the present time, industry has positive plans. for only one reservoir within the region--110 MWe at Roosevelt Hot Springs, Utah, by 1985. However, a number of excellent high-temperature prospects are known to exist. Two of these, Desert Peak, Nevada, and Valles Caldera, New Mexico, have reservoirs capable of generating electrical power. Many good low- and moderate-temperature prospects are also known in the region, but only a few of these are presently being studied. A very substantial increase in direct heat utilization is possible by 1985, if reservoir-confirmation efforts on these prospects are extensive enough.

Substantial funding will be provided by the Department of Energy with costshared high-temperature reservoir confirmation under the Industry-Coupled Case STudies program. This program offers industry financial assistance for reservoir confirmation holes, while at the same time making geoscience, reservoir engineering, and other results available to the public. A cylce of this program is initiated when the Department of Energy issues a Request for Proposals (RFP), which specifies acceptance criteria for 
hydrothermal exploration or reservoir confirmation. Industrial proposers respond with: a proposed exploration/confirmation program; a data package which is to be made public; and a proposal for cost-sharing with the Department of Energy. Contracts are negotiated with successful proposers, with the industrial concern acting as the project manager. The exploration/ confirmation program is initiated with DGE sharing the costs. The data package is delivered to the Department of Energy, which initiates interpretation, additional data collection and compilation, and publication of integrated case studies through the selected contractors.

Four of the region's numerous good prospects (in addition to Roosevelt Hot Springs) must be brought to the positive planning stage for power-plant construction by 1982, if 1985 goals are to be met. If the mid-and far-term electrical power goals are to be met, a substantial exploratory drilling program must be initiated by industry in areas that are now only prospects. The Industry-Coupled program will be required to cost-share drilling of at least 400 deep confirmation/production wells and at least 2000 therma $1-$ gradient wells through fiscal year 1984. Subsidiary exploration work designed to lead to the selection of these well sites will cost from 5 to $10 \%$ of the drilling costs, and the Industry-Coupled program must share in these expenses.

Definition and confirmation of low- and moderate-temperature resources will be accelerated by the State-Coupled Direct Heat program. The objectives of this program are to aid the U.S. Geological Survey in compiling data on low- and moderate-temperature resources, publishing maps and reports detailing these resources, and testing the highest priority areas for reservoir confirmation. It is believed that direct-heat uses of hydrothermal energy have the potential to replace a very significant amount of fossil-fuel use. No systematic survey of the low- and moderate-temperature hydrothermal resources of the United States has been made. The potential of the nation's abundant direct-heat hydrothermal resources is not being put to meaningfur use.

This program provides funding for an agency, institution, or laboratory within each state in the region to compile available data on low- and moderatetemperature hydrothermal resources, to publish maps and reports, and to 
test specific sites of greatest potential for direct-heat reservoir confirmation. The program also involves cooperating with the U.S. Geological Survey in assimilating the data generated into computer file GEOTHERM, and to help interpret the data. The Department of Energy contractors at the University of Utah/University of Utah Research Institute, and at the Los Alamos Scientific Laboratory are funded to aid in program management and to lend technical assistance where required. The National Oceanic and Atmospheric Administration is funded to collect data and publish the final state maps on geothermal resources.

The State-Coupled program presently provides important input into the Program Opportunity Notice (PON) program by identifying hydrothermal sites which are ready for development. It is anticipated that these state projects may lead to the initiation of an industry-coupled direct-heat program in selected states by 1982, and to further develop low- and moderate-temperature hydrothermal resources once the resource base is better understood.

\section{Technology Transfer}

Timely transfer of technology to industry and to other potential private and public users of hydrothermal resources is necessary in order to facilitate the development of hydrothermal resources and to foster a viable industry. It is anticipated that a large amount of data, information, and technological knowledge will be generated as a result of the resourcedefinition programs. In addition, a great deal of resource data and information already exist. However, there is no comprehensive source from which all of this valuable information may be obtained. Data and information collection and synthesis are necessary, and knowledge gained through these programs will freely be made available. This will be accomplished by maintaining a Regional Resource Data File; by giving technical assistance to potential users of geothermal energy; by synthesizing and publishing hydrothermal resource information; and by conducting workshops and presentations.

The Regional Resource Data File will physically house documents, maps, and samples. Cataloging and accessing of the data contained therein will 
be computer-based, but will not duplicate the U.S. Geological Survey's computer file GEOTHERM; rather, GEOTHERM will be a working part of the total regional data file. This data file will form a basic support element for industry- and private-sector geothermal development, or for federally funded and other hydrothermal programs. These data contained in the data file will be made available to the hydrothermal community.

The federal government will provide limited technical assistance to potential developers and users because the use of hydrothermal energy is not widespread and must quickly become so, and because the talent and expertise to promote rapid utilization is just now being developed. 


\section{TECHNOLOGY APPLICATIONS - ELECTRIC}

The Technology Applications - Electric program activity involves Barrier Identification, Power Plant Development Incentives, Industry-Coupled Well Stimulation, and Technology Transfer.

These tasks require different emphasis for the near-term goal (1985), than for the longer-range goals (2000 and 2020) shown in Table II. The 1985 goal will be accomplished utilizing existing technology and presently identified resources. The long-range goals will require more emphasis on the development of new technology, identification and confirmation of additional resources, and stimulation of well production.

\section{Barrier Identification}

The Barrier Identification task is designed to enhance the commercialization of hydrothermal energy by identifying technical and economic barriers, recommending approaches for eliminating these barriers, and providing guidance and instruction for mitigating the barriers which cannot be removed.

An analysis will be conducted to determine what effect the technical barriers have on the projected electrical power production. Technological needs for future power production will be identified as development proceeds toward the near-term goal. Economic sensitivity of the technical barriers will be determined, which will identify those technical areas which have the largest effect on the product cost to the consumer. These results will indicate in what order each technological barrier should be addressed. 
Power Plant Development Incentives

As the results of the Resource Definition task becomes available through the Industry-Coupled Program, the Raft River Facility activities and the Environmental program, Program Research and Development Announcements (PRDA's) will be issued to fund the planning phase for power plant development at specific sites. Each plan will identify potential industry, developer and utility participants and define the portion of the development for which each will be responsible. These plans will each describe the phases of the development program, milestones in the scheduled development, criteria for proceeding to subsequent phases, and schedules of government funding support.

Where it can be demonstrated that plans are viable and show economic feasibility, Program Opportunity Notices (PON's) will be issued for the preliminary design of power plants at specific reservoir sites. Once the design has progressed to a stage where the total economic picture is well understood and the plant promises to be competitive with other forms of energy, the government cost sharing will cease and the developers will proceed on their own. Consideration will be given in the selection process to the sites that will provide the maximum amount of power production for the minimum amount of government cost sharing.

\section{Industry-Coupled Well Stimulation}

The purpose of this program is to use a number of existing production and injection wells as a basis for assisting industry in developing their own well stimulation programs. Existing hardware, and existing methods and state-of-the-art techniques developed under the PRDAs generated by Los Alamos Scientific Laboratory will be utilized. This task will review the needs, make recommended approaches to well characteristic enchancement and provide the guidance and instruction necessary for an Industry-Coupled program and technology transfer. Program Opportunity 
Notices will be issued for the actual well stimulation testing at specific sites. Selection criteria will be based on demonstration capability. The major thrust will be to demonstrate that stimulation can be an effective method for increased well performance and thereby reduced the number of required wells.

Selected firms will be responsible for preparing and executing a stimulation plan with associated cost estimates leading to a timely application of known and tested stimulation technology. This responsibility will include procurement of the services of contractors necessary to implement this commercialization plan.

\section{Technology Transfer}

The results of the Barrier Identification, Power Plant Development Incentives and the Industry-Coupled Well Stimulation activities will be disseminated to the industry. The technical and economic barriers which will be identified and the results of the analysis will be made available. The information acquired for each power plant site development will be disseminated through workshops and included as background information for future PRDAs and PONs. Well stimulation PON results will be used to generate guidelines for industry. During and after the PON activities, technical assistance will be provided to industry to aid them in developing their own well stimulation programs. 


\section{TECHNOLOGY APPLICATIONS - DIRECT HEAT}

The Direct Applications Program is a balanced program developed to support a growing direct-applications industrial community, with the intention of expanding the utilization of moderate-temperature hydrothermal energy in direct applications. To insure the development of a viable industry, concentrated effort is required in many fields so that existing technical, economic, legal, institutional, environmental, and emotional barriers to hydrothermal utilization can be overcome.

The objective of this program is to establish a base and provide support for public and private development of direct-application uses. This program will take the required steps toward more widespread direct utilization of hydrothermal resources, to reduce the $U$. S. dependency on fossil fuels, and to conserve such exhaustable fuels. The mediumtemperature $\left(90\right.$ to $\left.150^{\circ} \mathrm{C}\right)$ and $10 \mathrm{w}$-temperature $\left(50\right.$ to $\left.90^{\circ} \mathrm{C}\right)$ hydrotherma 1 resources contain about four to five times as much recoverable heat as high-temperature (above $150^{\circ} \mathrm{C}$ ) systems, when recoverability practices are limited to current or near-term technology.

The majority of the hydrothermal resources in this country do not permit efficient generation of electrical energy with current or near-term technology. In many cases, the direct applications of hydrothermal energy are straightforward extensions of today's technology, and in all cases direct applications would mean the efficient utilization of this large energy resource. These observations are reinforced when worldwide hydrothermal resource-utilization practices are evaluated. In the U.S., the use of direct applications in process applications is almost nonexistent, because of our former abundance of cheap fossil fuels. With the emerging need for alternative energy choices for the future, the nation can no longer delay implementing the significant contributions that the nonelectric hydrothermal resources will make to meeting energy needs. 
Several key issues or barriers remain that impede the direct utilization of hydrothermal energy in the region:

- Uncertainties about economics and the environment,

- Lack of reservoir data which severely limits private investment,

- Difficulty in generalizing economics and use potential data (data are extremely site specific),

- Limited availability of experienced personnel,

- Lack of working relationships between users and energy suppliers,

- General absence of exploration/resource-development industry,

- Lack of low-temperature process equipment vendors,

- Lack of general (public) knowledge about the usability of hydrotherma 1 energy.

The major thrust of the direct-applications program must be made into the low-temperature utilization sector of industrial processing, industrial and residential space conditioning, and various agribusiness processes which are generally combined process/space conditioning uses.

The program selected to accelerate use of direct heat within the region contains three major areas of concentrated activity. They are:

- Accelerating assessment of the available hydrothermal resource within the region (this element is called the State-Coupled Program).

- Generating definitive economic and technical data for various representative direct applications. This is considered to be the single most important action that can be taken to stimulate growth in the use of hydrothermal energy. Field projects by industries at their facilities appear to be the most direct means for industry to gain hands-on experience with reasonable corporate risk. This task is called Field Projects. 
- Directing the use of hydrothermal energy in processing and space conditioning. This concept must be marketed. Commonly called Technology Transfer, this task must be carried out in conjunction with each ongoing technical activity, to ensure that information about engineering, utilization techniques, legal and institutional changes, and environmental issues are made available to the public and private sectors. From such knowledge, investment capital can be made available to strengthen and develop a viable directapplications hydrothermal-energy industry.

The Field Projects work element which is discussed below is the focal point of the Direct-Applications Program. The thrust of the Direct-Applications Program will be structured using this task as its guiding principle. The basic philosophy of the regional commercialization, to put power on line quickly and effectively, is outlined below:

- Early effort must be focused on low-temperature industrial processing, with secondary effort on retrofit space heating. This is being effected by the large food industry, through the Program Opportunity Notice (PON), and the retrofit space-heating PON's that ensued from the first PON release. The first regional PON will stress low-temperature process applications.

- The second series of PON's will stress applications located at new resources, to insure continued growth as new resources are developed. Space conditioning (both heating and cooling) will have a second-order importance. 
- Industries and communities will have to be developed around viable resources, because most resources are not located near cities or industries. The third PON will stress this utilization technique.

- The region is large, comprising different climates, embracing many potential industrial processes, and containing resources of varying temperature and quality. Therefore, PONs will be spread throughout the political boundaries of the region as much as technically possible.

In addition to the effort contained in this commercialization plan, several national programs, such as the Department of Energy's geothermal loan guarantee plan, are relied upon to insure rapid commercialization.

\section{Field Projects}

This task consists of the Federal Buildings Program and Program Opportunity Notice (PON) field projects. The field projects program area is the heart and the major thrust of the direct-applications program. These elements are the basis for data collection for technology transfer, and they provide guidance concerning necessary areas for additional technologyapplications development. These elements are the high-visibility activities required to provide the socioeconomic and technological data base for the general stimulation of direct-applications uses.

The objective of the Federal Building Program is to stimulate commercial interest in the direct uses of hydrothermal energy by demonstrating the viability of resource applications in federal installations. All potential applications have not been totally defined, but facility heating will be the major thrust. This effort for the region is coordinated with the generic programs sponsored by the Department of Energy. This element of the program will be a synergistic program coordinated with various federal agencies, such as the Department of Health, Education, and Welfare and the Department of Defense. 
The PON field projects will constitute the major near-term thrust of the direct-applications program. The purpose of the PON field projects is to assist parties interested in building utilization projects for demonstrating the single or multiple uses of hydrothermal energy, such as industrial processing, space and hot-water heating, space cooling, agriculture, or aquaculture. Field projects are needed to provide visible evidence of the viability of various direct-heat applications in a number of geographical regions, to obtain, under field-operating conditions, reliable data that will facilitate utilization decisions by perspective developers and users, and to demonstrate different types of applications.

Applied Technology

A number of incentives, such as the PONs, PRDAs, and Loan Guarantee Program, are provided to advance the commercialization of hydrothermal heat as an industrial direct-application energy resource. In addition to these incentives, the technical feasibility of harnessing this energy remains a concern, regardless of statements about availability and nearterm technology. Proof-of-principle and pilot testing continue to be important incentives to the demonstration and full-scale application of industrial processes. Without this type of test information, many potential users of hydrothermal resources could ignore the hydrothermal option.

The applied technology tasks involve a number of subtasks in applied research tests and experiments, all directed toward a more widespread understanding of the potential for the beneficial uses of hydrothermal fluids for direct applications. The subtasks are: Components and Materials Applications, Systems Analysis and Applications, Industrial, Commercial, and Residential Utilization, and Beneficial Uses. 
Barrier Identification and Coordination

Proof-of-principle evaluations are required to determine the potential technical and economic viability of direct applications in industry. Barrier identification and coordination efforts are composed of three main efforts: the Program Research and Development Announcement (PRDA) Engineering and Economic Studies, Case Studies, and Special Engineering and Cost-Evaluation Studies.

\section{Technology Transfer}

The culminating step in all of the tasks within this program is the transfer of the technology from the developing groups or agencies to users. Without this transfer of knowledge, the hydrothermal industry could never develop. A program has been developed to insure that technology transfer will be carried out to the fullest extent possible. Included in this activity are: User Assistance, Education, Information Dissemination, Industrial Involvement, and Regional Coordination.

The objective of the User Assistance task is to provide assistance to the general public, industry, Department of Energy contractors, and other entities. Users may consult with regional program personnel concerning materials technology, engineering, heat transfer, and program planning. Priorities for assistance requests from industry and the general public will be established on a first-come, first-serve basis. As user assistance contacts are made, and as proposed projects materialize, assessments of additional PON applicability or of other mechanisms will be pursued to further stimulate the direct utilization of hydrothermal energy.

Industrial participation is required to insure that hydrothermal energy moves easily into the commercial segment. Included in the industrial involvement task are such program elements as the development of hydrothermal input for segments of the ASHRAE Heating and Ventilating Guide, and the involvement of industrial participants in the general Department of Energy program. 


\section{ENVIRONMENTAL CONTROL}

The key objective in the regional plan for managing Environmental Control is to fulfill the mission statement of developing hydrothermal resources in an "environmentally acceptable manner". The manner in which this activity will be carried out by the Department of Energy contractors is to provide strong regional environmental support and to transfer environmental technology to developers during the period 1978-1990.

\section{Regional Environmental Support}

A key element in providing regional environmental support will be accomplished by the development of environmental preplans for each subregion in the Rocky Mountain Basin and Range Region. This environmental preplan will be a compilation of all available environmental data pertaining to the region. This includes data on air quality, meteorology, seismicity, subsidence, water quality, ecology, geology, hydrology, resource-use, demography and socioeconomics, history, and archeology. The preplan will be available through an environmental data bank and will describe what data are needed, what data are already available, and the quality of the data in the specific area, for either electric or direct application development. The preplan and baseline survey are funded by the Division of Biomedical and Environmental Research (B\&ER) of the Department of Energy.

The preplan for Roosevelt Hot Springs is presently underway and is being prepared by the Lawrence Livermore Laboratory. The preplan for the Snake River Plain is now being prepared by EG\&G Idaho, Inc., and should be completed in early 1979. Subregional environmental preplans should be completed by 1985 for the entire Rocky Mountain Basin and Range Region. In those cases where the Department of Energy is the major participant in hydrothermal development, at their or the developers request, environmental-baseline-data collection and monitoring will be coordinated through the environmental-control group. Raft River is such a program which will continue through 1988. 
A majority of the preplan and site-specific monitoring funds will go directly to commercial or university contractors, with coordination and technical direction by the environmental-control group. Increased funding requirements reflect this need to supplement the regional baselines as the specific development areas are identified.

Private and public developers will be provided, upon request, technical environmental assistance. This assistance will include program definition, methods, evaluation, technical assistance, and Environmental Impact Assessment and Environmental Impact Statement document preparation and review.

Regulatory and technical liaison with local, state, and federal regulatory and planning agencies will be maintained. Existing regulations and policies which affect hydrothermal development will be identified. As requested by those agencies, technical and advisory assistance will be provided for the development and review of proposed regulations and policies, to insure that hydrothermal commercialization is carried out in an environmentally sound manner.

Any technical or advisory assistance that is required by contractors under the Loan Guarantee, Program Opportunity Notice (PON), and Program Research \& Development Announcement (PRDA) programs will be provided. This includes preparation of any additional or supporting documents required by the Department of Energy, assistance with document preparation, review of programs to determine compliance with regulations, and review of environmental monitoring programs.

\section{Technology Transfer}

The objective of this part of the environmental control program is to provide for the transfer of hydrothermal environmental information among all who are involved in hydrothermal commercialization. A clearing- 
house will be established to identify and coordinate environmentalresearch and data-collection efforts that would be of interest to geotherma 1 developers. An environmental data file will be maintained for each subregion and will be available to any developer or researcher seeking environmental data for the preparation of environmental assessments, the development of monitoring programs, or the support of research programs.

A responsive environmental education program will be established. This program will be designed to provide developers, regulatory agencies, and the general public with environmental information on a timely basis. 


\section{RAFT RIVER FACILITY}

The Raft River Facility is being developed to advance the frontiers of commercialization of moderate-temperature hydrothermal resources. Two 5-MW(e) power plants of advanced design will be constructed and operated for at least five years. Direct applications involving experimentation in grain drying, farming, and aquaculture will be demonstrated using resource temperatures between 143 and $149^{\circ} \mathrm{C}$. Industry will be encouraged to participate in all facility operations, and a program of technology transfer via tours and information dissemination will be instituted. The work schedule is shown in Figure 60.

\section{First. 5-MW(e) Power Generation System (First 10op)}

The first Raft River 5-MW(e) power system will generate electrical power from a $143^{\circ} \mathrm{C}$ resource with a binary organic cycle. Design has been completed, and plant construction will start in 1978. The plant will be placed in operation in 1980, and will be operated for at least five years to obtain long-term plant-performance data, evaluate reservoir performance, and assess any environmental effects.

An industrial group will be encouraged to operate the plant in partnership with the Department of Energy. The personnel who will be operating commercial plants in the late eighties and nineties will thus gain direct experience in overcoming operating problems. A series of tests will be made as the plant operates, to determine the performance of each component and to provide design data necessary for improved commercial plant designs.

Second 5-MW(e) Power Generation System (Second 10op)

A second $5-M W(e)$ power generation system will be constructed at Raft River to apply advanced concepts, developed by industry and the Department of Energy engineering groups, to the Raft River moderate-temperature hydrothermal resources. The plant will demonstrate to industry the economic advantages which can be obtained using the advanced engineering concepts. 


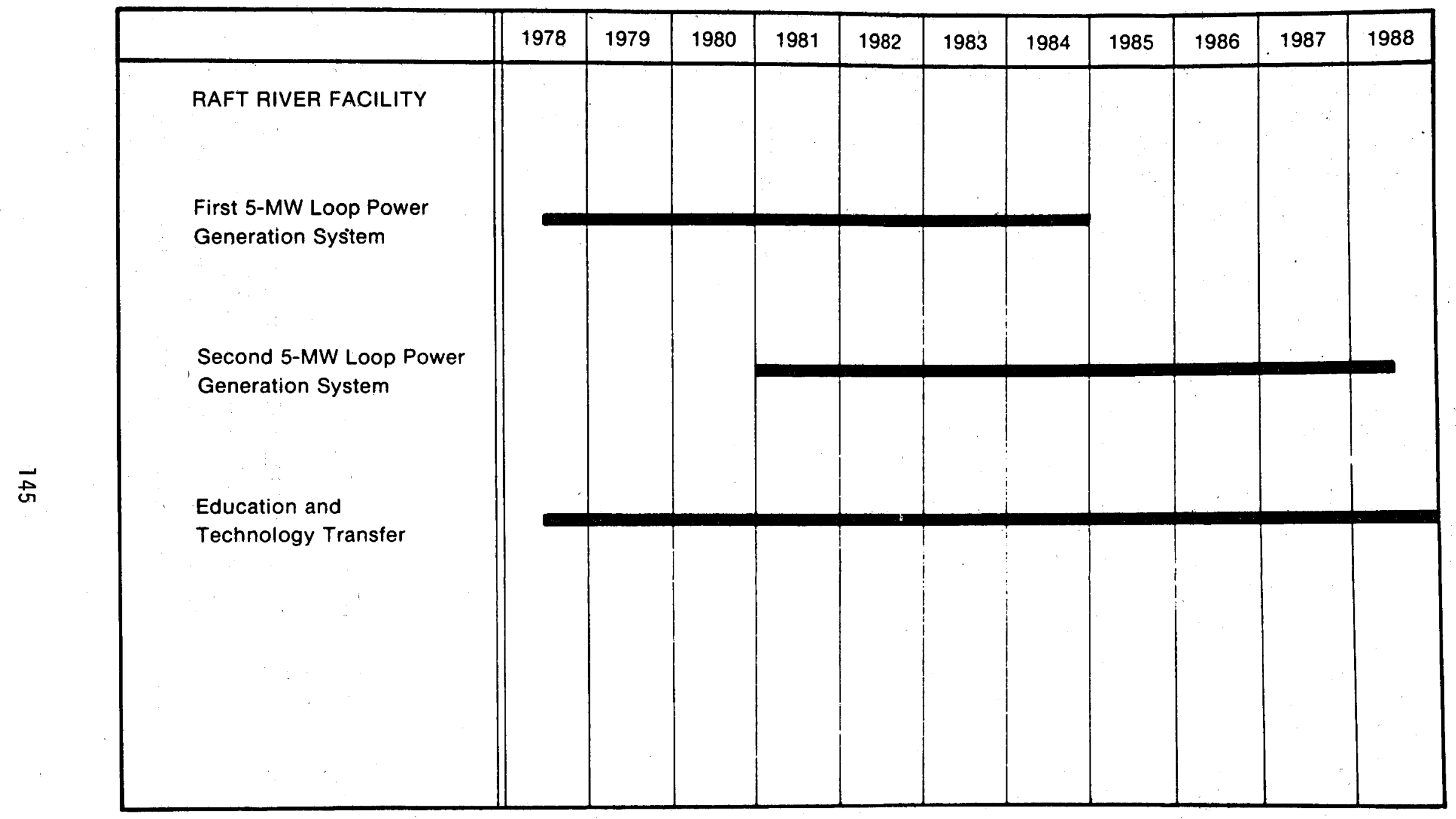

Fig. 60. Raft River Facility Schedule 
The plant will use direct contact boilers and condensers, and a hybrid cooling system. Production- and injection-well placement will be arranged to optimize reservoir utilization in terms of both power requirements and hardware and drilling costs. The plant will serve as a standard for moderate-temperature resource utilization, and will be operated for at least five years by a commercial operator. Instrumentation will be provided to obtain detailed component performance and operating data.

The entire Raft River area will be closely monitored for environmental impacts during the operation of both power plants. Data will be obtained on seismic effects, ground water, air quality, local wildlife, and 'vegetation. These data will be published regularly to assist commercial operators in preparing environmental impact statements for planned facitities.

The Raft River reservoir will be monitored closely to improve the basic understanding of reservoir performance. These data will be published regularly to assist reservoir analysis in commercial areas.

\section{Education and Technology Transfer}

A program of escort teams and education lectures will be conducted at the Raft River facility. All direct applications and power systems at the facility will be displayed so that visitors can understand how hydrothermal energy is being applied. A visitors center will contain exhibits that will portray the potential of the region's hydrothermal installations, and the Department of Energy projections for future uses will be displayed. Brochures will be available to define the entire range of hydrothermal energy use, from power production at high temperature through space heating at low temperatures.

Tours will begin in the visitors center and proceed through the experimental areas. Tour guides will present the entire hydrothermal energy story, including information about available resources, current use, and planned use, and they will explain the objectives of hydrothermal applications at the facility. Visitors to Idaho will be encouraged to visit the Raft River facility, and an active program of tours for students, civic groups, and industry groups will be initiated. 


\section{PRINCIPAL DOE REGIONAL TEAM PARTICIPANTS}

The planning and implementation of the Rocky Mounta in Basin and Range regional program involves the active participation of federal, state, and private sectors. The Department of Energy's regional program primarily involves participants from the Department of Energy's Division of Geothermal Energy, and Idaho Operations Office, EG\&G Idaho, Inc., and the Earth Science Laboratory (University of Utah/University of Utah Research Institute). Table VII lists the principal regional team participants. Prime responsibilities are as follows:

Division of Geothermal Energy, DOE. The program manager, Rocky Mountain Basin and Range Region, acting with the concurrence of the director, Division of Geothermal Energy (DGE), provides overall programmatic guidance for the definition, planning, direction, and control of the regional program. DOE-DGE provides overall financial guidance to the Department of Energy-supported participants in the program, including subprogram-level guidance to the Geothermal Program at the Idaho Operations office. The region program manager is also responsible for coordinating the regional program with national geothermal program elements contained within the Department of Energy and other agencies participating in the national geothermal program.

Idaho Operations office. The Idaho Operations office will serve as the focal point for all the Rocky Mountain Basin and Range (RMB\&R) Region geothermal activities. Its management responsibilities will include the planning, scheduling, implementing, and reporting of all regional programs.

The Idaho Operations office will contract with private industry and individuals in order to carry out the Department of Energy's hydrothermal activities. The DOE-ID office will rely upon the technical staff of EG\&G Idaho, Inc. and the University of Utah Research Institute Earth Science Laboratory to conduct selected work segments and provide a 
variety of support functions for the regional programs. The DOE-ID office will interface directly with the local and state governmental agencies within the ten states which comprise the Rocky Mountain Basin and Range Region.

EG\&G Idaho, Inc. EG\&G Idaho, Inc, prime contractor at the Idaho National Engineering Laboratory, will have the lead responsibility for the detailed planning, coordination, and actual implementation of engineering aspects and environmental control of the regional program. In addition to its role as prime contractor for various engineering field applications and facilities projects, EG\&G Idaho, Inc. will provide overall planning support for the regional program, which includes regional program coordination, policy development, and state commercialization planning coordination.

University of Utah/University of Utah Research Institute Earth Science Laboratory (UURI). UURI will have lead responsibility for the planning and coordination of Department of Energy-supported regional resourcedefinition activites. UURI is responsible for developing detailed resource-definition plans in support of the regional electric and directheat application goals. UURI will initiate field programs and/or provide assistance to individual Department of Energy-supported resourcedefinition projects, such as the state coop program, as approved by the DOE Idaho Operations Office.

The services of professional groups within the region will be solicited to provide additional expertise to the regional program where special needs exist. 


\section{TABLE VII}

PRINCIPAL DOE REGIONAL TEAM

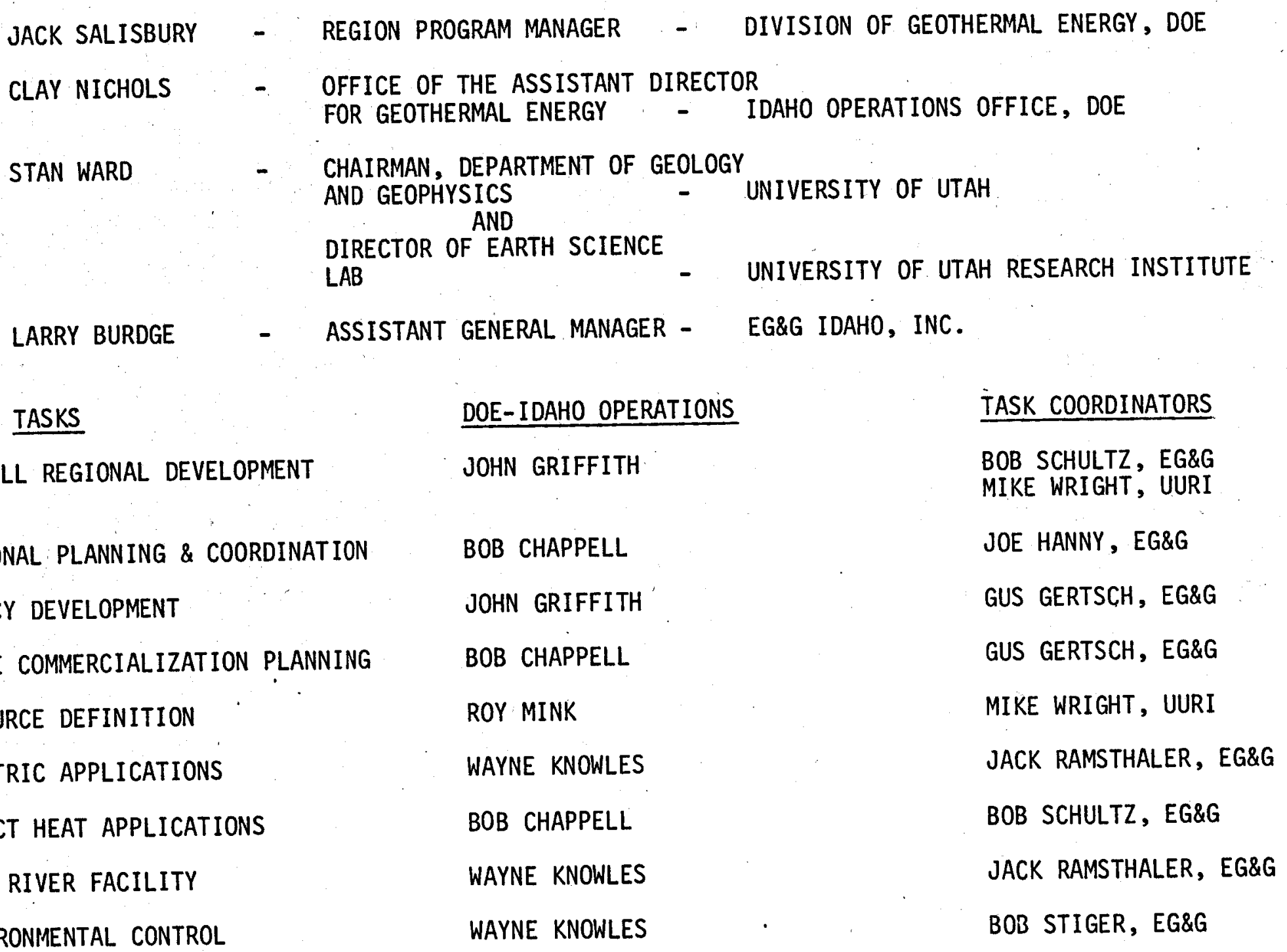


APPENDIX A

GEOLOGIC PROVINCES

SUBREGION I: SNAKE RIVER PLAIN

Subregional Setting

The Snake River Plain and the Yellowstone volcanic field constitute a major young volcanic province extending in a broad arc from the IdahoOregon state line eastward across Idaho to Yellowstone National Park and vicinity (see figure 36 ). The common geologic element in the region is the volcanic activity as indicated by the young basaltic rocks at Craters of the Moon in the eastern Snake River Plain and the massive young rhyolitic volcanic deposits and associated basalts of the eastern Snake River Plain and Yellowstone.

The Snake River Plain is an area of generally low relief which is covered by basaltic lava flows interbedded with young, flat-lying river and lake deposited sedimentary rocks. The plain contains a large proportion of the state of Idaho's irrigated agricultural lands, and most of its population centers. The northeastern portion of the plain is terminated by a generally circular, forested, silicic volcanic feature, the Island Park Caldera. The Is land Park Caldera borders the higher plateaus and mountains of Yellowstone National Park immediately to the east. Radiometric dating indicates that the volcanism has progressed eastward along the plain toward Yellowstone.

The Eastern Plain has been characterized as a downwarps, and geophysical surveys indicate 3 to $5 \mathrm{kms}$ of sedimentary and volcanic fill within the trough. The primary recharge area for the Snake River Plains aquifer is the high snowfall region in the Island Park area. The outflow area is at Thousand Springs near Buhl in the canyon of the Snake River. Scattered 
young silicic volcanic centers are present both within the eastern plain and marginal to it within the Blackfoot Volcanic Field.

The western plain has been described as a rift valley. Volcanism in the western plain is older than that of the eastern plain and no specific prospects based on young rhyolitic volcanism have been identified.

\section{Geothermal Potential}

Confirmed geothermal resources of the area are of low and moderate temperature; and are presently being exploited for a variety of direct heat uses. Known geothermal resources within the subprovince are primarily associated with normal faulting along the margins of the Snake River Plain.

Young silicic volcanic rock within the eastern plain and the high temperature geothermal systems at Yellowstone National Park indicate the potential for igneous-related high temperature resources in the eastern plain. The high flow rate Snake River Plains aquifer is responsible for obscuring the high heat flow that may be associated with such hidden resources.

Moderate temperature geothermal systems are indicated by geochemical thermometry for the western Snake River Plain. High temperatures $\left(\sim 200^{\circ} \mathrm{C}\right)$ have been reported from deep exploration wells in the area, but no high temperature fluid production has been confirmed.

The fracture zones paralleling the northwestern trend of the plain contain at least moderate temperature geothermal resources along both the northern and southern flanks of the western Snake River Plain. The Bruneau-Grandview area adjacent to the plain on the south is notable in this respect. At least a 12 by 60 mile area contains hot fluids at depths of 1000 to 3000 feet. The region may extend from Twin Falls near the eastern most portion of the western plain, more or less, continuousty to the Oregon state line near Vale. 
Approach

Based on existing resource data, near-term geothermal utilization within the subregion will be primarily a continuation and expansion of direct heat applications of the low and moderate temperature geothermal resources. Resource definition programs will insure that potential users are made more fully aware of the geothermal potential existing throughout the subregion and, together with the Program Opportunity Notice (PON) program for direct heat application, will maximize the replacement of fossil fuel used to create low grade energy with geothermal resources. The midterm electrical generation goal from high temperature resources will be largely dependent on the successful exploration for the hidden resources of the deep Snake River Plain. Impediments to industry exploration of the subregion without government support include both the masking of the deep thermal situation by the cold Snake River Plains aquifer and the drilling difficulties anticipated in drilling through the volcanic sequence. A combination of ongoing USGS and Department of Energysupported assessment, combined with cost-shared drilling with industry, is expected to establish the high temperature geothermal potential of the Snake River Plain by 1982 .

The midterm utilization of the extensive moderate-temperature resources for electrical power generation will depend on the successful development of moderate temperature electrical generation technology at Raft River.

SUBREGION II: NORTHERN ROCKY MOUNTAINS

\section{Subregional Setting}

The Northern Rocky Mountain subregion (see Figure 36 ) is a mountainous area characterized by, rugged topography, extensive forests and low population density. The subregion is here defined as those portions of Montana and northern Idaho characterized by the presence of batholiths 
and folded mountain ranges exclusive of the young volcanic provinces of the Yellowstone and Snake River Plain.

The combined Idaho and Boulder Batholiths comprise much of central Idaho and southwestern Montana. The area geologically is dominated by batholithic complexes of intermediate to silicic rocks of Cretaceous age ( 90 million. years before present). The batholiths are similar in composition and age to the Sierra Nevada Batholith.

The southern and western margins of the Idaho Batholith contain faulted sediment basins such as Little Camas Prairie, which provide ideal reservoir conditions with approximately $2 \mathrm{~km}$ of sedimentary fill.

In addition to the batholithic ranges, the subregion contains northtrending, folded, sedimentary mountains such as the Sawtooth Range in central Idaho.

\section{Geothermal Potential}

The Northern Rocky Mountain subregion has a widespread potential for the discovery and development of low- and moderate-temperature geothermal resources. There is no geochemical or geologic evidence for the existence of very high temperatures suitable for electrical power generation. Wide spread moderate and low temperature resources are localized by the presence of fractures and fault zones. Heat flow throughout at least the Idaho Batholith and Boulder Batholith is known to be high and virtually any recently active fault zone within this portion of the subregion has a potential for providing a moderate temperature resource through deep convective circulation. Hot springs and shallow, moderate temperature, hydrothermal resources are particularly common along structural zones within the Idaho Batholith. 


\section{Approach}

The geothermal program in this subregion will emphasize the stimulation of the development of moderate temperature resources for direct heat applications. Individual communities and industries within this natural gas-dependent area will provide the primary targets for development of the geothermal resources for direct heat applications. The program will be implemented largely through the State-Coupled and Direct Heat Application programs. The widespread occurrence of hard rock mining throughout the subregion presents both an opportunity for expanded utilization of natural hot waters in mineral beneficiation and an institutional question concerning the status of geothermal rights versus mineral rights.

SUBREGION III: WASATCH FRONT

\section{Subregional Setting}

The Wasatch Fault Zone and its northern continuation as the Teton Fault Zone through southeastern Idaho to the southern border of Yellowstone volcanic field contains a disproportionate percentage of the subregion's population and land suitable for agricultural purposes. The Wasatch Fault Zone marks a sharp boundary between the Basin and Range Province to the west and the Wasatch Range to the east. The western margin of the Wasatch Front subregion generally corresponds to a zone of seismic activity known as the Intermountain Seismic Belt, which continues on northward in the Northern Rocky Mountains past Yellowstone through western Montana to the Canadian border near Glacier National Park. The Uinta,Uplift, the Wind River Range and the associated overthrust belts are also included within this subregion. 


\section{Geothermal Potential}

The technologically active margins of the subregion, which border the Basin and Range subregion, contain low- and moderate-temperature geothermal resources suitable for direct heat applications. The general absence of young volcanism within the subprovince is negative evidence concerning the potential for the discovery of the $+200^{\circ} \mathrm{C}$ fluid resources suitable for electrical generation in the near-term. The fortunate coincidence of the area's population centers with widespread low- to moderatetemperature resources associated with the Wasatch Fault Zone provides a major opportunity for direct heat applicaitions.

$0 i 1$ and gas exploration of the overthrust belt of southeastern Idaho has provided direct confirmation of the presence of moderate temperature resources. Water near the boiling point has been produced from carbonate aquifers at depths of less than $2 \mathrm{~km}$ at several points in Jeton Valley.

\section{Approach}

The near-term geothermal program for the Wasatch Front subregion will emphasize the acceleration of the development of low- and moderatetemperature resources for direct heat applications. This will be accomplished by means of the inventory of these resources in cooperation with state agencies in Utah and Idaho and the geothermal program of the U.S. Geological Survey. Following the initial inventory of the resources which will be completed in fiscal year 1978, the program will emphasize site specific studies and projects designed to bring the resource to the attention of the potential users. A significant impact on new energy requirements for low grade heat will be possible through an ambitious program which addresses markets in the private and public sector. 


\section{SUBREGION IV: COLORADO PLATEAU}

\section{Subregional Setting}

The Colorado Plateau and the young volcanic ranges which occur around its margin with the Basin and Range Province are here considered as a single subregion. The Colorado Plateau is roughly a circular area bounded on the west and south by the Basin and Range Province and on the north and east by the Wasatch Front and southern Rocky Mountains. Topographically, the plateau is divided into a number of individual uplifts and basins which range in elevation from 5000 to 11,000 feet. The margins of the plateau contain a number of relatively young volcanic ranges with a significant geothermal potential. These include the Mineral Range in southwestern Utah, the San Francisco Peaks near Flagstaff, Arizona, the White Mountains in southcentral Arizona, the Zuni Uplift in northwestern New Mexico and the San Juan Range of southwestern Colorado.

\section{Geothermal Potential}

The interior of the Colorado Plateau is generally thought to be a relatively low heat flow province. The margins of the plateau, however, contain major confirmed high-temperature geothermal systems associated with young silicic volcanic centers. The Roosevelt-Cove Fort-SulfurdaleThermo KGRAs in southcentral Utah constitute a major electrical generation resource which is being actively developed by industry with Department of Energy support.

Young volcanic centers in central and eastern Arizona include the San Francisco Peaks and the White Mountains. These regions have not been explored by deep drilling but appear promising on the basis of their geologic setting, regional heat flow measurements and limited geochemical data. The Zuni Uplift in northeastern New Mexico is interesting but its potential is less substantiated. 
Approach

The young volcanic fields marginal to the Colorado Plateau constitute a high priority target within the total region. Acceleration of the rate of development of the known fields in southern Utah in order to meet the 1985 and 2000 gaals will be accomplished primarily by means of the industry-coupled drilling program which was initiated in fiscal year 1977. Further drilling in adjacent KGRAs will be encouraged during subsequent solicitation programs. The rate of development of these reservoirs will also be accelerated by means of case studies of the data set provided by the industrial participants in the program.

The utilization of by-product fluids produced by electrical generation at these fields will be encouraged through an expanded regionwide PON program for direct heat applications.

$0 i 1$ and gas exploration within the Colorado Plateau will be carefully monitored for abnormal gradients encountered during the oil and gas exploration. The margins of the plateau will receive particular emphasis in state-USGS cooperative origins with Arizona, Utah, New Mexico and colorado. These programs are designed to target reservoirs suitable for direct heat applications, which the PON program will help make available to potential users.

\section{SUBREGION $V$ : BASIN AND RANGE}

\section{Subregional Setting}

The Basin and Range subregion is a major physiographic province which includes most of Nevada, southwestern Arizona, western Utah, southwestern New Mexico and a small portion of southern Idaho. The subregion includes block-faulted basins and ranges which are generally north-south trending. 
The subregion is arid to semiarid and characteristically is composed of desert lands and closed drainages. Although basaltic and rhyolitic lavas dated 6 to 20 million years before present are common throughout the province, there are very few young rhyolitic centers. The region has a higher than normal heat flow, and hot springs and wells, particularly in northcentral and eastern Nevada.

\section{Geothermal Potential}

The subregion has a widespread moderate-temperature resource which is almost universally present along fracture zones within the region. Geochemically predicted base reservoir temperatures of $150^{\circ}$ to $200^{\circ} \mathrm{C}$ are relatively common and temperatures as high as $240^{\circ} \mathrm{C}$ are predicted for some fields. Although the Basin and Range Province is characterized by its high heat flow, the thermal gradients measured throughout the region are by no means uniform. High gradients are especially common in a region of northcentral Nevada known as the Battle Mountain High. This area of unusually high heat flow does not appear to be associated with any known igneous heat source, but rather is an area of abnormally high gradient superimposed on the regional high.

The area of the Battle Mountain High continues to be the object of considerable industry interest in exploration for electrical generating capacity. The western most portion and its boundary with the Sierran Front seems to possess the high temperature geothermal potential. Prospects with confirmed high temperatures include Steamboat Springs, Brady Hot Springs and Grey's Peak.

Approach

In view of the interest displayed by industry in the electrical generating capacity of resources of the northern Basin and Range, this region has been targeted for the second initiative of the Industry-Coupled Program, 
beginning in 1978. Significant questions remain as to the nature of the heat source driving the numerous moderate and possibly high temperature systems. The Industry-Coupled Program will be designed to both stimulate the drilling and development of the numerous systems in the area and also to acquire detailed subsurface data which will be valuable in accelerating industrial rate of successful discoveries. A modest program of low- and moderate-temperature reservoir identification is planned in cooperation with the United States Geological Survey and state agencies. This program will seek as its main thrust to replace existing energy consumption in the region for mineral beneficiation at sites where mineral processing and the geothermal resources are co-located.

SUBREGION VI: RIO GRANDE RIFT - SOUTHERN ROCKY MOUNTAINS SUBREGION

\section{Subregional Setting}

The major feature of this subregion is the Rio Grande Rift, a structural depression located just west of the Sangre De Cristo Range of northern New Mexico, which extends southward through central New Mexico to the Texas border at El Paso. Also included in the subregion are the southern Rocky Mountains, which extend from the Laramie Range in southern Wyoming to the Sangre De Cristo Range. The region is mountainous with elevations to 14,000 feet. The subregion is bounded on the east by the Great Plains and on the west by the Colorado Plateau and Wyoming Basin.

\section{Geothermal Potential}

The subregion has a demonstrated high temperature reservoir which is being developed by Union 0il Company at the Valles Caldera near Los Alamos in northern New Mexico. The Caldera lies along the Rio Grande $\mathrm{Rift}$ on the margin of the Colorado Plateau. The presence of high-temperature geothermal reservoirs at other sites along the Rift have been postulated. but not confirmed. The Rift does constitute a favorable region for high 
temperature geothermal system discoveries. The remainder of the subprovince, particularly the more northern ranges, do not appear to have a high temperature potential. Known geothermal occurrences through the San Luis Valley in southern Colorado and near Alenwood Springs in northern Colorado confirm that at least a moderate temperature resource is present throughout this region.

\section{Approach}

The Industry-Coupled program will be initiated in or before 1981, and will be designed to stimulate industry exploration for high temperature systems within the Rio Grande Rift. The State-Coupled program and the PON program for direct heat applications will be employed in order to stimulate the development of low- and moderate-temperature geothermal resources in the major population centers of the region.

\section{SUBREGION VII : GREAT PLAINS}

\section{Subregional Setting}

The Great Plains subregion is a major physiographic province lying east of the Rocky Mountains. For the purposes of this program the Wyoming Basin is included within the Great Plains subregion. The Great Plains are underlain by eastward dipping sedimentary rocks of tertiary age. A number of individual mountain ranges, including the Black Hills of South Dakota, are present within the subregion. The Williston Basin is a large sedimentary bas in centered to the northeast of the Black Hills in Montana, North Dakota, and northwestern South Dakota.

The principal deep freshwater aquifer throughout much of the subregion is the Madison Limestone. 


\section{Geothermal Potential}

The Great Plains subregion contains no identified igneous point sources and the geologic environment does not suggest the presence of high temperature geothermal systems. Heat flow throughout most of the region is normal or near-normal and, as a result, moderate temperature convective systems are not common. The subregian does contain widespread accurrences of hot water in the Madison Aquifer, which has been locally utilized for direct heat applications. A significant development for space heating is presently underway in South Dakota under the PON program. Water near the boiling point is produced from the Madison Formation near Casper and Sheridan, Wyoming, making these urban areas potential users of geothermal energy for direct heat applications. 
APPENDIX B

DEFINITIONS

Confirmed Reservoir - A reservoir that has been proven capable of production of hydrothermal fluids in amounts sufficient to attract a user.

Constant 1978 Dollars - Nominal 1978 dollars, not subject to inflation, projection or other value fluctuations and for which use is made for future capitol expenditures based upon 1978 dollar values.

Geothermal - Geothermal resources are the natural heat of the earth's crust. This natural energy is economically significant, however, only when it is concentrated into restricted volumes in a manner analogous to the concentration of valuable metals into ore deposits or of oil into commercial petroleum reservoirs.

Geothermal Prospect - An area where a geothermal reservoir is inferred, but not proven to exist, through surface manisfestations or indirect geoscience evidence.

Hydrothermal - Geothermal energy as the heat contained by water either in a liquid, vapor or mixture of both states. The term is used to differentiate from geothermal resources whose heat is contained in geopressured, magma, hot dry rock or normal gradient forms.

High Grade Reservoirs - Hydrothermal resources with temperatures above $200^{\circ} \mathrm{C}$ and sufficient extractable fluid avallable.

Inferred Resource - That part of the resource that has been inferred by geological, geochemical and geophysical data to lie within the useful accessible resource base.

Low Temperature - Energy requirements which can be met by energy resources providing heat at temperatures less than $150^{\circ} \mathrm{C}$.

Moderate Temperature Reservoirs - Hydrothermal resources with temperatures ranging between $150^{\circ} \mathrm{C}$ and $200^{\circ} \mathrm{C}$.

MW - Megawatt $=1,000,000$ watts, the watt is an electrical power unit used to define the time rate at which work is done.

PON - Program Opportunity Notice (PON). The purpose of the Program Opportunity Notice is to provide an opportunity for interested parties to propose direct heat utilization or combined electric/ direct use (nonelectric) projects demonstrating single or multiple usages of geothermal energy for Federal Government support. 
Potential Resource - That resource which is indicated by existing well data, but which requires additional drilling to be confirmed.

PRDA - Project Research and Development Announcement (PRDA). Government sponsored engineering and economic analysis studies directed towards development of particular aspects of hydrothermal utilization.

Proven Reserves - That part of the resource that has been identified by sufficient wells and deemed economic on the basis of well tests and economic analysis, and for which plans have been made for power on stream.

Quad - A unit of energy defined as $10^{15}$ BTU, or one quadrilition BTU.

RMB\&R - Literally, the Rocky Mountain Basin and Range; however, in general, this definition is meant to include the ten state region where the major physiographic provinces are the Rocky Mounta in provinces (South, Middle and Northern), and the Basin and Range province. Also, included in this definition are portions of the northern and eastern parts of the Great Plains province, the Wyoming Basin, the Colorado Plateau, the Snake River Plain, the Wa satch Front and the Rio Grande Rift. 